Universidade de Brasília

Instituto de Ciências Biológicas

Departamento de Biologia Celular

Programa de Pós-Graduação em Biologia Molecular

\title{
Filogenia molecular e cultivo de Archaea de solos de Cerrado sensu stricto
}

\author{
Aline Belmok de Araújo Dias
}

Dissertação apresentada ao Programa de Pós-Graduação em Biologia Molecular do Departamento de Biologia Celular, Instituto de Biologia, Universidade de Brasília, para a obtenção do título de Mestre em Biologia Molecular.

Orientadora: Dra. Cynthia Maria Kyaw 
Dedico esta dissertação à memória de minha querida avó Eloá, que sempre me incentivou na busca pelo conhecimento e cujos carinho e amor me fazem muita falta. 


\section{AGRADECIMENTOS}

Em primeiro lugar gostaria de agradecer a minha orientadora, Cynthia Kyaw, por toda a ajuda, paciência e apoio ao longo destes anos. Seus conselhos e orientação presente foram essenciais para o desenvolvimento deste trabalho. Tive muita sorte de tê-la como orientadora. Muito obrigada por tudo Cynthia!

Agradeço aos meus pais, Elder e Luciana, que sempre me apoiaram em todas as minhas decisões e mesmo sem entender muito bem do que se tratavam essas tais de archaeas, sempre estiverem dispostos a me escutar ao longo destes anos. Sou muito grata pelo incentivo e apoio incondicionais de vocês.

Aos meus irmãos, tios, primos e avôs, pela constante presença, carinho e apoio, muito obrigada!

Ao meu amor, Diego, que sempre esteve ao meu lado, compartilhando de cada alegria e conquista e me confortando e apoiando nos momentos mais difíceis, muito obrigada pelo companheirismo.

Tenho muito a agradecer também às pessoas que tornam meu dia-a-dia tão agradável e divertido no laboratório: Thiago Rodrigues, Deborah Vasconcellos, Letícia Mallmann e Letícia Velasco. Muito obrigada pelas risadas, amizade, companhia e ajuda. De forma especial, gostaria de agradecer ao Thiago, por toda a ajuda e paciência durante as análises de bioinformática e pelas inúmeras contribuições intelectuais.

Agradeço à professora Heloísa Miranda pelo grande auxílio com as coletas de solo e discussão de informações referentes a ecologia do Cerrado.

Também gostaria de agradecer ao professor Ricardo Krüger por sua colaboração com esta pesquisa.

Agradeço à Ingrid e ao Cláudio, membros do laboratório de Microscopia da Unb, por toda a disponibilidade e ajuda na preparação de amostras para análises de microscopia. 
Aos responsáveis pelo sequenciamento do Laboratório de Biologia Molecular da UnB, em especial ao Bruno Sales, pelo sequenciamento de parte das amostras deste trabalho, muito obrigada.

Gostaria de agradecer à querida Cinthia Bonatto, por toda a paciência e perseverança nas tentativas de análise das células cultivadas por microscopia de força atômica e por toda as conversas e dicas. Agradeço também ao Prof. Luciano Paulino por disponibilizar seu laboratório e equipamentos.

Também tenho muito a agradecer ao amigo Marco Oliveira, sempre disposto a me escutar lamentar sobre cada experimento que deu errado. Obrigada pelas muitas conversas, risadas, histórias e visitas ao laboratório.

Não posso deixar de agradecer aos meus coleguinhas biológicos, grandes amigos desde os tempos de graduação, que tanto me aconselharam e escutaram ao longo do mestrado: Stefânia, Luíza, Ester, Chael, Amanda, Thiago, Diogo, Gabriel, Anderson, Gabriela, Marco e Guilherme.

Agradeço também às queridas Mariana, Camila, Karina, Nathália, Michelle, Fernanda e Fabiana, amigas desde os tempos de infância, que mesmo sem entenderem de biologia sempre escutaram atentas as minhas histórias.

Por último, quero agradecer a Carl Woese e a seus colaboradores, que revolucionaram os estudos em microbiologia e "descobriram” Archaea, este fascinante domínio da vida. 


\section{LISTA DE FIGURAS E TABELAS}

Figura 1. Árvore filogenética de Archaea a nível de filo, construída a partir de 38 genes marcadores concatenados. Retirado de Rinke et al., 2013.

Figura 2. Fotos das áreas de Cerrado sensu stricto onde foram coletadas as amostras de solo. Em A, área Controle, que não sofria queimadas há mais de 15 anos e em B área Queimada, submetida a queimadas bienais.

Figura 3. Precipitação mensal registrada na Reserva Ecológica do IBGE, ao longo do ano de 2013. Dados obtidos na página da Reserva (www.recor.org.br/cid360/download/17-dadosmeteorológicos.html).

Figura 4. Perfil eletroforético, em gel de agarose $1 \%$ corado com brometo de etídio, do DNA total extraído do solo das áreas Controle $(\mathrm{Ca}, \mathrm{Cb}, \mathrm{Cc})$ e Queimada (Qa, Qb e Qc), em triplicata.

Figura 5. Géis de agarose $1 \%$ corados com brometo de etídio, contendo os fragmentos do gene rRNA 16S amplificados por PCR, utilizando-se os iniciadores 21f/958r.

Figura 6. Géis de agarose $1 \%$ corados com brometo de etídio contendo os fragmentos do gene amoA amplificados por PCR, utilizando-se os iniciadores Arch amoAf/Arch amoAr...34

Figura 7. Perfil eletroforético do DNA plasmidial, contendo fragmentos do gene rRNA 16S de amostras de Controle e Queimada, de clones recombinantes aleatoriamente selecionados. .36

Figura 8. Curvas de rarefação obtidas para a amostra Ca para os valores de 3, 5,10 e $20 \%$ de dissimilaridade.

Figura 9. Curvas de rarefação obtidas para a amostra $\mathrm{Cb}$ para os valores de 3, 5, 10 e $20 \%$ de dissimilaridade.

Figura 10. Curvas de rarefação obtidas para a amostra Cc para os valores de 3, 5, 10 e $20 \%$ de dissimilaridade.

Figura 11. Curvas de rarefação obtidas para a amostra Qa para os valores de 3, 5, 10 e $20 \%$ de dissimilaridade. 
Figura 12. Curvas de rarefação obtidas para a amostra Qb para os valores de 3, 5, 10 e $20 \%$ de dissimilaridade.

Figura 13. Curvas de rarefação obtidas para a amostra Qc para os valores de 3, 5, 10 e $20 \%$ de dissimilaridade.

Figura 14. Diagrama de Venn representando as OTUs exclusivas e compartilhadas a nível de espécie (3\%) nas réplicas de Controle $\mathrm{Ca}, \mathrm{Cb}$ e $\mathrm{Cc}$.

Figura 15. Diagrama de Venn representando as OTUs exclusivas e compartilhadas a nível de espécie (3\%) nas réplicas de Queimada Qa, Qb e Qc.

Figura 16. Diagrama de Venn representando as OTUs exclusivas e compartilhadas a nível de espécie (3\%) nas amostras de Controle e Queimada, sendo Controle $=\mathrm{Ca}+\mathrm{Cb}+\mathrm{Cc}$ e Queimada $=\mathrm{Q} a+\mathrm{Qb}+\mathrm{Qc}$.

Figura 17. Gráfico de Análise de Principais Coordenadas (PCoA) gerado através de coordenadas obtidas pelo comando Weighted Unifrac no programa Mothur e construído no programa PAST3. .56

Figura 18. Árvores filogenéticas com as sequências dos representantes de cada OTU (3\%) das réplicas de Controle $\mathrm{Ca}, \mathrm{Cb}$ e $\mathrm{Cc}(\mathrm{A})$ e das réplicas de Queimada $\mathrm{Qa}, \mathrm{Qb}$ e Qc (B) alinhadas com sequências de archaeas cultivadas e não cultivadas retiradas do banco de dados do NCBI..

Figura 19. Árvore filogenética com as sequências do gene rRNA $16 \mathrm{~S}$ dos representantes de cada OTU (3\%) de Controle e Queimada alinhadas com sequências de archaeas cultivadas e não cultivadas retiradas de banco de dados do NCBI.

Figura 20. Histograma indicando a distribuição das sequências de Controle $(\mathrm{Ca}+\mathrm{Cb}+\mathrm{Cc})$ e Queimada (Qa+Qb+Qc) entre os grupos I.1b e I.1c de Thaumarchaeota.

Figura 21. Árvore filogenética com as sequências de $a m o A$ representantes de cada OTU (3\%) de Controle e Queimada alinhadas com sequências de amoA de archaeas cultivadas e não cultivadas retiradas de banco de dados do NCBI.....

Figura 22. Tipos coloniais obtidos em meios de cultura inoculados com o solo de cerrado...

Figura 23. Tipos coloniais obtidos após o repique do tipo colonial 2 em meio de cultura com bacitracina e norfloxacina. 
Figura 24. Coloração de Gram dos diferentes tipos coloniais obtidos..

Figura 25. Coloração de Gram das células do tipo colonial 2 após crescimento em meio adicionado de bacitracina e norfloxacina....

Figura 26. Células do tipo colonial $2 \mathrm{~A}$ observadas por microscopia eletrônica de varredura. Os aumentos utilizados estão indicados abaixo de cada imagem.

Figura 27. Células do tipo colonial 2B observadas por microscopia eletrônica de varredura. Os aumentos utilizados estão indicados abaixo de cada imagem.

Figura 28. Gel de agarose $1 \%$ corado com brometo de etídio, contendo os DNAs extraídos das colônias cultivadas a partir do solo de cerrado.

Figura 29. Gel de agarose 1\%, corado com brometo de etídio, revelando os produtos de PCR obtidos de A: colônias 2 e 3, empregando-se os iniciadores 21f/958r. B: Reamplificações das amostras 2 e 3 (Reamp. 2 e Reamp. 3), utilizando-se o DNA obtido no primeiro ensaio de PCR como molde. .86

Figura 30. Gel de agarose $1 \%$ corado com brometo de etídio mostrando o DNA amplificado após reação de PCR com iniciadores 27f/1492r, específicos para o gene do rRNA 16S de Bacteria.

Figura 31. Árvore filogenética com a sequência do gene rRNA $16 \mathrm{~S}$ da archaea cultivada (denominada Cultivada Cerrado e marcada com o retângulo vermelho) alinhada com sequências de archaeas cultivadas e não cultivadas retiradas de banco de dados do NCBI....92

Figura 32. Árvore filogenética com a sequência do gene rRNA $16 \mathrm{~S}$ da archaea cultivada (denominada Cultivada Cerrado e marcada com o retângulo vermelho) alinhada com sequências de archaeas cultivadas e não cultivadas retiradas de banco de dados do NCBI.... 96

Tabela 1. Iniciadores específicos para os genes do rRNA 16S e amoA de Archaea utilizados nas reações de PCR.

Tabela 2. Condições dos ensaios de PCR com os iniciadores específicos para os genes do rRNA $16 \mathrm{~S}$ e amoA de Archaea.

Tabela 3. Iniciadores específicos para o gene do rRNA 16S de Bacteria empregados nas reações de PCR com o DNA extraído das colônias cultivadas. 
Tabela 4. Valores dos parâmetros físico-químicos dos solos de Cerrado sensu stricto coletados nas áreas Controle e Queimada.

Tabela 5. Concentrações dos DNAs extraídos das diferentes amostras de solo, aferidas pelo espectrofotômetro Nanophotometer da IMPLEM.

Tabela 6. Número de clones recombinantes obtidos para cada amostra e par de iniciadores..

Tabela 7. Número de sequências analisadas por bioinformática para cada amostra. .37

Tabela 8. Classificação taxonômica das sequências do gene rRNA $16 \mathrm{~S}$ gerada pelo Greengenes.

Tabela 9. Número de sequências, OTUs e singletons obtidos em cada amostra. 43

Tabela 10. Índices de riqueza (Chao1 e ACE), diversidade (Shannon e Simpson), número de OTUs observadas (Sobs) e a cobertura para cada uma das réplicas de controle $(\mathrm{Ca}, \mathrm{Cb}$ e $\mathrm{Cc})$ e Queimada (Qa, Qb e Qc) em cada um dos coeficientes de dissimilaridade.

Tabela 11. Teste de hipótese $\int$-Libshuff entre as réplicas de Controle e Queimada. .54

Tabela 12. Número de OTUs observadas (Sobs) e cobertura obtida em cada réplica de Controle e Queimada para o gene amoA. 70

Tabela 13. Valores dos parâmetros físico-químicos do solo de Cerrado sensu stricto coletado na área Controle, para o estabelecimento do cultivo.

Tabela 14. Sequências amplificadas em cada tipo colonial obtido no cultivo. .88 


\section{SUMÁRIO}

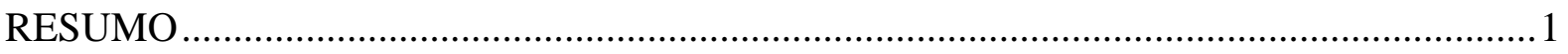

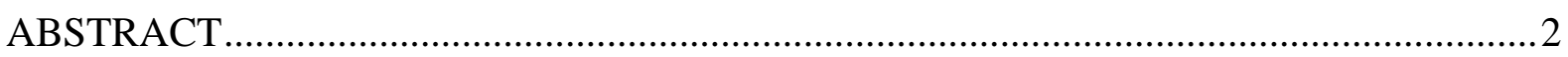

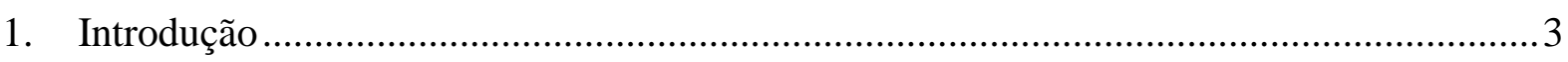

1.1. O estudo da filogenia e taxonomia de procariotos ............................................. 3

1.2. O domínio Archaea ....................................................................................................

1.3. Ubiquidade de Archaea .....................................................................................

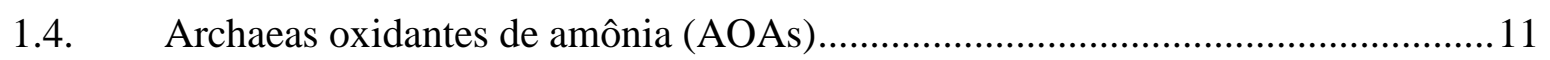

1.5. Importância do cultivo laboratorial de microrganismos ....................................... 12

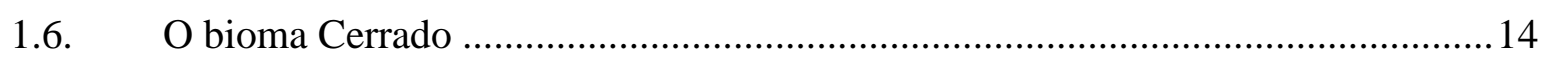

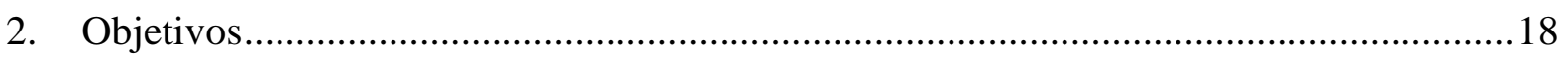

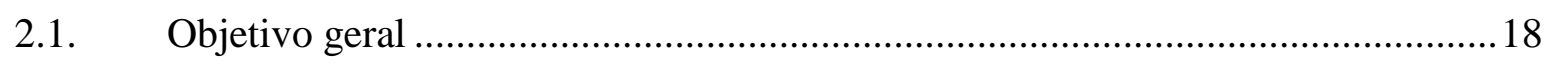

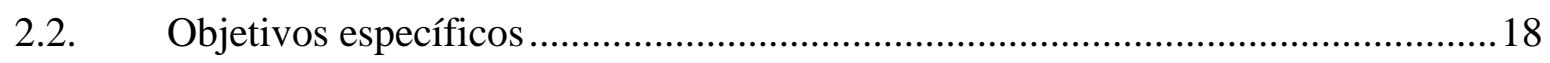

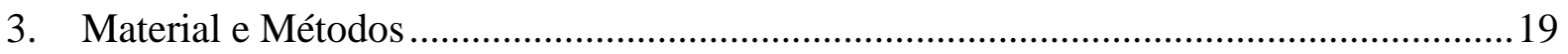

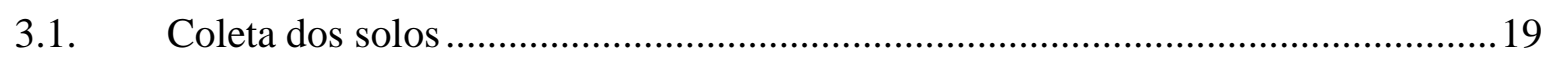

3.2. Confecção dos meios de cultura, inóculo inicial e manutenção das culturas ........20

3.3. Coloração de Gram das células do cultivo e visualização por microscopia óptica20

3.4. Visualização por Microscopia Eletrônica de Varredura (MEV) ...........................21

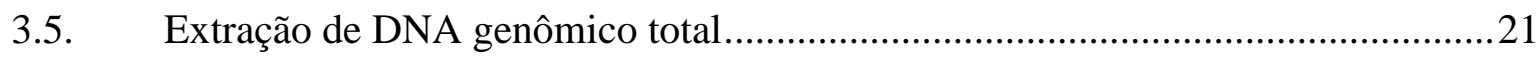

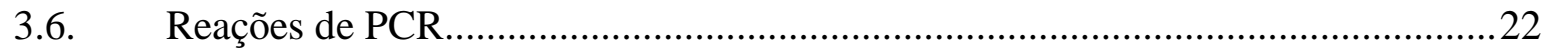

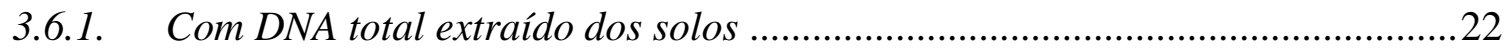

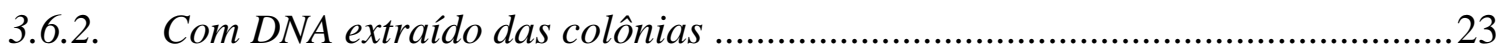

3.7. Purificação e ligação dos fragmentos amplificados no vetor pGEM-T easy ........24

3.8. Preparação de células competentes Escherichia coli DH5 a..................................24

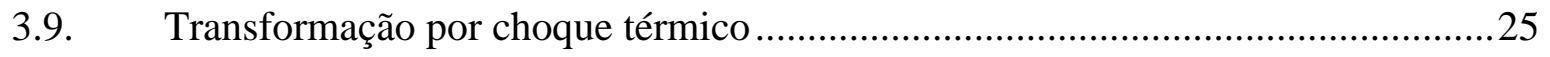

3.10. Seleção e estoque em glicerol dos clones recombinantes....................................25

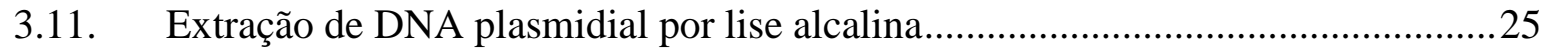

3.12. Sequenciamento de DNA e análises de bioinformática.........................................26

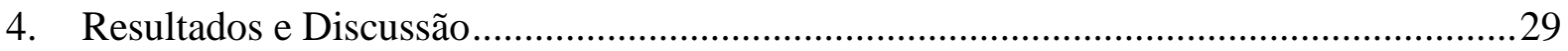

4.1. Filogenia molecular de Archaea em solos de Cerrado sensu stricto submetidos ou não

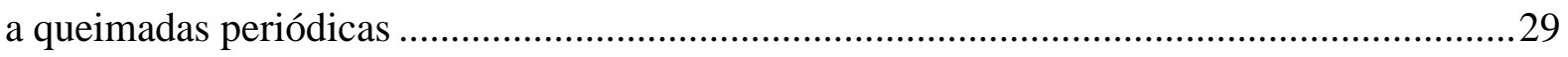

4.1.1. Coleta dos solos e análises dos seus parâmetros físico-químicos ........................29

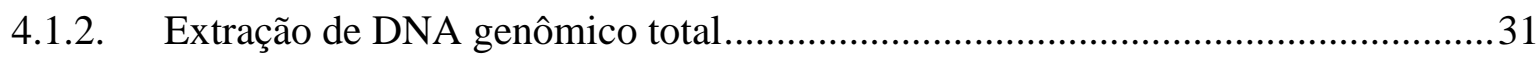


4.1.3. Amplificação de fragmentos dos genes do rRNA $16 \mathrm{~S}$ e da subunidade A da

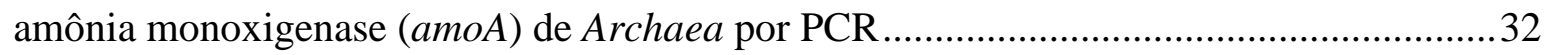

4.1.4. Transformação de Escherichia coli DH5 $\alpha$ e seleção de clones recombinantes ....35

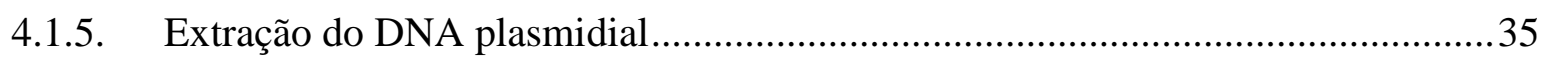

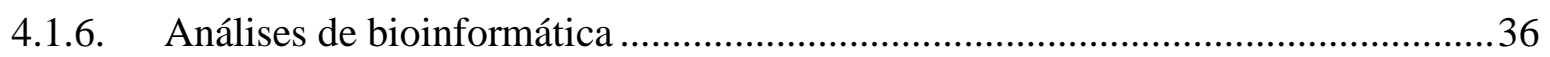

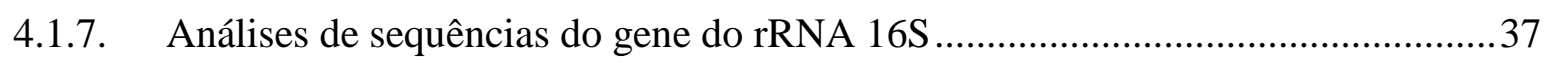

4.1.7.1. Classificação taxonômica pelo banco de dados Greengenes ..........................37

4.1.7.2. Análises de riqueza e alfa-diversidade .......................................................... 41

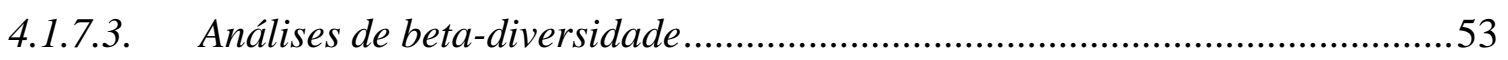

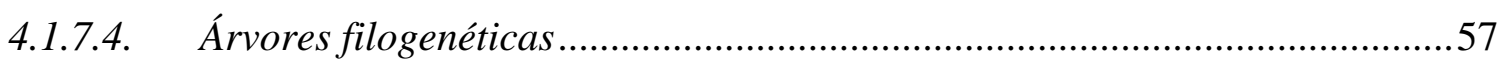

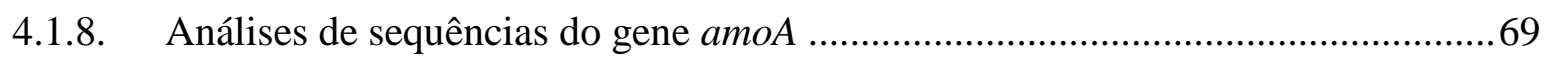

4.2. Obtenção de culturas de Archaea em meios artificiais ................................................73

4.2.1. Coleta dos solos e análises dos seus parâmetros físico-químicos .........................73

4.2.2. Obtenção de culturas de Archaea em meios artificiais.........................................74

4.2.3. Coloração de Gram e visualização das células do cultivo por microscopia de luz79

4.2.4. Visualização por Microscopia Eletrônica de Varredura (MEV) ........................... 82

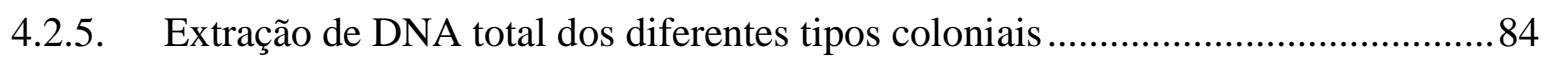

4.2.6. Experimentos de PCR empregando-se iniciadores específicos para o gene de

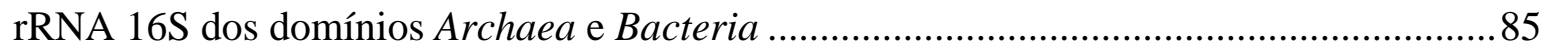

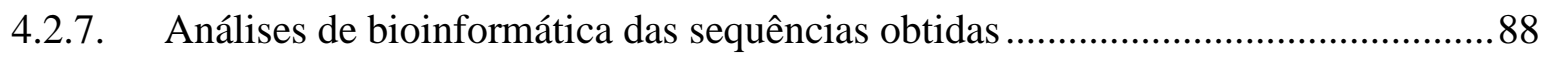

4.2.7.1. Classificação taxonômica pelo banco de dados Greengenes ..........................89

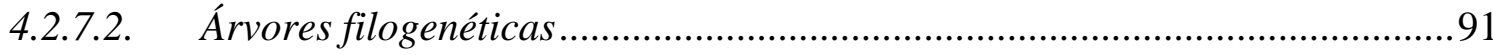

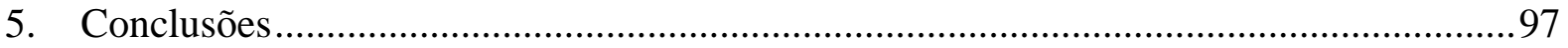

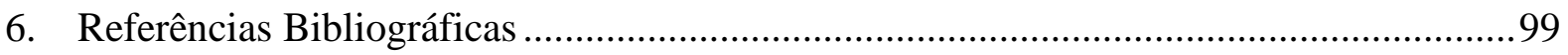




\section{RESUMO}

Há quase 25 anos foi proposto que os procariotos poderiam ser divididos em dois domínios distintos: Bacteria e Archaea. As archaeas foram inicialmente associadas apenas a ambientes extremos, mas com o aumento do uso de abordagens moleculares, membros deste domínio passaram a ser detectados em diversos habitats do nosso planeta, evidenciando sua ubiquidade. Além disso, posteriormente foram identificadas archaeas com metabolismos de importância ecológica que antes acreditavam-se estar restritos a bactérias, como a oxidação de amônia. Apesar dos avanços trazidos pelas técnicas moleculares, a obtenção de cultivos laboratoriais ainda é imprescindível para a compreensão de vários aspectos da biologia dos microrganismos. No Brasil, ainda são escassos os estudos sobre Archaea nos diferentes ambientes naturais. O Cerrado é um extenso e importante bioma de nosso país, mas pouco se sabe sobre a comunidade de archaeas nos solos de suas diferentes fitofisionomias. Além disso, queimadas são eventos ecológicos importantes no Cerrado e não existem estudos sobre o seu efeito na população de archaeas de solos deste ambiente. Assim, este trabalho teve como objetivo avaliar e comparar a comunidade de Archaea em solos de Cerrado sensu stricto que não sofrem queimadas há anos e solos de áreas queimadas bienalmente, além da detecção de archaeas com potencial para oxidação de amônia nestes solos. Outro objetivo do trabalho foi a obtenção de culturas de archaeas provenientes do solo deste bioma. Amostras de solo coletadas em triplicata foram submetidas à extração de DNA total, que foi utilizado em ensaios de PCR com os iniciadores específicos para os genes rRNA 16S e amoA de Archaea. Os resultados obtidos revelaram que a grande maioria das sequências obtidas pertence aos grupos I.1b e I.1c do filo Thaumarcheota. No entanto, apesar das semelhanças encontradas nas análises realizadas, as amostras de solo da área protegida do fogo apresentaram maior abundância de thaumarchaeotas do grupo I.1c, enquanto o solo da área queimada apresentou mais sequências do grupo I.1b. Análises do gene amoA, amplificado em todas as amostras, indicaram archaeas com o potencial para a oxidação de amônia possivelmente não descritas anteriormente ocorrendo nos solos de Cerrado. Para o estabelecimento do cultivo de archaeas do solo de Cerrado, meios de cultura foram confeccionados a partir de um coado de solo e suplementados com agentes antimicrobianos. Após vários repiques, o DNA das colônias observadas foi extraído e amplificado com iniciadores para os domínios Archaea e Bacteria. A análise das sequências obtidas indicou uma cocultura entre uma bactéria do gênero Novosphingobium e uma archaea do grupo I.1c de Thaumarchaeota, que ainda não apresenta qualquer representante cultivado descrito na literatura. 


\section{ABSTRACT}

It has been almost 25 years since the proposal that divided prokaryotes in two different domains: Bacteria and Archaea. The archaea were initially associated exclusively with extreme environments, but the increasing utilization of molecular approaches revealed that members of this domain were ubiquitous and could be detected in different environments on Earth. Furthermore, metabolisms of ecologic importance that were thought to be restricted to bacteria were later detected in archaea, such as the ability to oxidize ammonia. This fact highlights that, despite the advances brought by molecular approaches, cultivation of microorganisms in laboratory is still essential for understanding many aspects of their biology. Currently, there are very few studies about Archaea in the natural environments of Brazil. The Brazilian savanna, known as Cerrado, is an extensive and important biome of our country, but little is known about the Archaea community in soils of its different phytophysiognomies. Furthermore, fires are important ecological events in Cerrado and there are no studies about its effects on the Archaea populations in soils. Therefore, this study aimed to evaluate and compare the archaea community of Cerrado sensu stricto soils of an area that has long been protected from fire and another that has been submitted to biennial prescribed fires. It also aimed to detect archaea with the potential for ammonia oxidation in these soils. Another objective of this study was the establishment of archaea from Cerrado soils in culture. Soil samples were submitted to DNA extraction, which was used for PCR essays with specific primers for Archaea rRNA 16s and amoA genes. Results showed that most of the sequences obtained were from I.1b e I.1c groups of Thaumarchaeota. Despite the similarities found in the analysis, samples from the protected site showed higher abundance of I.1c thaumarchaeotes, while in samples from the frequently burned site more sequences from group I.1b were detected. Analysis of the $a m o A$ gene, which was amplified from all samples, showed that there are possibly previously undescribed archaea with ammonia oxidation potential in Cerrado soils. For the establishment of archaea cultures, culture media were made from soil filtrates and supplemented with antimicrobial agents. After several transfers, DNA extracted from the obtained colonies was used for PCR essays with specific primers for Archaea and Bacteria domains. The sequences obtained revealed a coculture between a bacteria of Novosphingobium genus and an archaea from group I.1c of Thaumarchaeota, a group that so far does not have any cultured representative described in the literature. 


\section{Introdução}

\subsection{O estudo da filogenia e taxonomia de procariotos}

Durante muitos anos, a classificação dos seres vivos pelos taxonomistas teve como base a análise de características morfológicas dos organismos. Desta forma, a classificação filogenética de procariotos foi por muito tempo considerada impossível, em virtude da simplicidade morfológica e difícil detecção de características diagnósticas nestes organismos microscópicos (Rosselló-Mora \& Amann, 2001). No início do século XX, com o desenvolvimento das metodologias de cultivo em meios artificiais, parâmetros bioquímicos e fisiológicos passaram a ser utilizados na tentativa de classificação dos microrganismos (Schleifer, 2009). No entanto, apesar de classificações baseadas em características fenotípicas terem sido úteis para os microbiologistas, estas são instáveis e as relações evolutivas dos procariotos não podem ser bem estabelecidas por essas abordagens (Krieg, 1988).

Em 1965, Zuckerkandl e Pauling postularam que informações acerca da história evolutiva de um organismo poderiam ser extraídas de seu genoma. Em seu trabalho, os autores discutem que existem diferenças no material genético que não são observadas nos polipeptídios, já que diferentes códons podem ser traduzidos em um mesmo resíduo de aminoácido e, desta maneira, o material genético carregaria mais informações filogenéticas e poderia ser utilizado para o estudo de relações evolutivas entre os organismos. A partir deste conceito, uma nova era na taxonomia microbiana teve início e abordagens moleculares passaram a ser utilizadas no estudo e na classificação dos procariotos (Fox et al., 1977).

Inicialmente, a comparação geral entre a composição de bases dos genomas bacterianos (conteúdo de $\mathrm{G}+\mathrm{C}$ ) foi utilizada para propósitos de classificação taxonômica, mas os valores obtidos permitiam apenas classificações superficiais (Krieg, 1988). O desenvolvimento de técnicas de hibridização DNA-DNA, no início da década de 70, trouxe novas contribuições para a sistemática bacteriana e permitiu o agrupamento dos organismos de acordo com suas semelhanças genéticas. Essa técnica baseia-se na premissa que, sob condições padronizadas, fitas de DNAs de organismos diferentes se reassociarão, dependendo do grau de similaridade de suas sequências de nucleotídeos, permitindo assim uma quantificação de similaridade entre estas (Rosselló-Mora \& Amann, 2001). Atualmente, dados referentes à hibridização DNA-DNA ainda são utilizados como critério para a delimitação de novas espécies, sendo o limiar de $70 \%$ de similaridade empregado para se definir se dois organismos pertencem ou não a mesma espécie (Stackebrandt et al., 2002). 
Outra abordagem molecular que passou a ser amplamente utilizada nos estudos de taxonomia e filogenia de procariotos foi a catalogação de ácidos nucleicos ribossomais (rRNAs ou os genes que codificam os rRNAs). Tais moléculas são excelentes cronômetros evolutivos, por serem universais, ou seja, encontradas em todos os organismos, e apresentarem homologia funcional e evolutiva (Olsen \& Woese, 1993). Além disso, sequências de rRNA apresentam regiões de extrema conservação e regiões hipervariáveis, possibilitando que tanto as relações filogenéticas distantes quanto as próximas possam ser examinadas (Fox et al., 1977). O tamanho da molécula utilizada é uma característica essencial nas reconstruções filogenéticas, já que cada posição individual na sequência carrega informações de um estreito tempo evolutivo e um número maior de regiões na sequência aumenta a quantidade de informações filogenéticas que podem ser detectadas (Ludwig \& Schleifer, 1994). Desta forma, o rRNA 16S é mais adequado para estudos filogenéticos de procariotos do que o rRNA 5S, por exemplo, já que o primeiro apresenta aproximadamente 1500 nucleotídeos, enquanto o último tem apenas cerca de 120 (Olsen et al., 1986).

Outros genes conservados podem ser utilizados como marcadores filogenéticos no estudo da diversidade de procariotos, como genes que codificam proteínas ribossomais, proteínas de ligação ao DNA e amino-acil sintetases (Torvsk \& Øvreas, 2006). No entanto, o o rRNA 16S é um marcador filogenético amplamente utilizado, existindo um número cada vez maior de sequências de seu gene disponíveis em bancos de dados (Rappé \& Giovannoni, 2003), tornando-o uma importante ferramenta nos estudos de diversidade e filogenia microbiana.

A utilização de sequências de rRNA 16 S como marcador filogenético levou a grandes avanços no estudo da filogenia e taxonomia de procariotos, tendo sido inclusive empregada nos trabalhos de Woese e Fox (1977), que resultaram na descoberta de que os procariotos dividiam-se em dois grupos filogeneticamente independentes. Além disso, o desenvolvimento e aprimoramento de técnicas que permitem a obtenção e sequenciamento do gene do rRNA $16 \mathrm{~S}$ de procariotos (e 18S de eucariotos) diretamente de amostras ambientais possibilitaram estudos mais abrangentes de ecologia microbiana, permitindo a detecção e o posicionamento filogenético de microrganismos presentes nos mais diversos ambientes sem a necessidade de cultivá-los em laboratório (Amann et al., 1995). 


\subsection{O domínio Archaea}

Em 1977, Carl Woese e George Fox, por meio da comparação de sequências de RNA ribossomal $16 \mathrm{~S}$ de vários organismos, verificaram que os procariotos se dividiam em dois grupos distintos e propuseram então as denominações "eubactéria" e "arqueobactéria" para estes grupos. Nesta divisão, o reino das eubactérias seria composto por todas aquelas bactérias até então já bem conhecidas e o reino das arqueobactérias pelas bactérias produtoras de metano, genericamente chamadas de metanogênicas. Este último grupo foi assim denominado por acreditar-se, na época, que as metanogênicas seriam ancestrais das demais bactérias.

Estudos posteriores levaram Woese e colaboradores, em 1990, à proposta de um novo sistema de classificação taxonômica para os seres vivos. Esse sistema, de caráter filogenético, propunha a criação de um táxon superior a Reino, denominado Domínio, e a divisão de todos os seres vivos nos domínios Eukarya, Bacteria e Archaea. Desta forma, todos os eucariotos estariam incluídos em apenas um domínio e os procariotos seriam divididos em dois grupos. Além disso, as até então denominadas arqueobactérias passariam a ser chamadas apenas de Archaea, evidenciando-se assim as grandes diferenças filogenéticas entre estes organismos e as bactérias. Tal proposta levantou muitas controvérsias, mas com a crescente utilização de abordagens de filogenia molecular, mostrou-se muito coerente e revelou um grupo de procariotos até então pouco conhecido e estudado: as archaeas.

Organismos do domínio Archaea apresentam características em comum tanto com bactérias quanto com eucariotos, além de possuírem aspectos únicos. Uma das características mais marcantes desse domínio talvez seja relacionada à composição e estrutura de sua membrana plasmática. Diferentemente dos eucariotos e das bactérias que possuem seus ácidos graxos de membrana ligados ao glicerol-3-fosfato por uma ligação do tipo éster, as archaeas não apresentam cadeias de ácidos graxos, mas sim cadeias laterais de hidrocarbonetos que se ligam a moléculas de glicerol-1-fosfato por meio de ligações do tipo éter (Kates et al., 1993). Os hidrocarbonetos de membrana são essencialmente polímeros de isopreno, contendo de 20 a 40 unidades de carbono. Outra peculiaridade da membrana das archaeas é a presença de monocamadas lipídicas em algumas espécies ao invés do conhecido padrão de bicamada presente em todos os eucariotos e bactérias. Nas monocamadas, a fluidez é modulada pela ciclização de alguns componentes das cadeias laterais dos hidrocarbonetos, um importante fator na manutenção da estrutura da membrana de hipertermófilos (DeRosa et al., 1991). 
A parede celular das archaeas não apresenta peptideoglicano, que é um componente da parede celular de todas as bactérias. Sua composição é extremamente variável e as diversas espécies de archaea podem apresentar pseudopeptideoglicano, metanocondroitína, heteropolissacarídeos sulfatados, halomucina ou glutaminoglicano (Albers \& Meyer, 2011). Muitas archaeas podem apresentar também, ou ter como único envoltório celular, uma camada proteica cristalina denominada camada S. Essa camada é geralmente composta por apenas um tipo de proteína ou glicoproteína variando de 40 a $200 \mathrm{kDa}$ e, na maioria das archaeas, encontra-se aderida à membrana plasmática (Sleytr \& Sara, 1997). Uma interessante característica dessas proteínas formadoras da camada $\mathrm{S}$ é sua capacidade de se auto-organizarem em arranjos cristalinos bidimensionais, normalmente de formato hexagonal nas archaeas (Albers \& Meyer, 2011).

O cromossomo de Archaea é circular e a replicação ocorre de forma bidirecional, semelhante ao que acontece nas bactérias. No entanto, a maquinaria responsável por esse processo poderia ser descrita como uma versão simplificada da encontrada nos eucariotos (Ishino \& Ishino, 2012). No que diz respeito aos sistemas relacionados à transcrição e tradução do material genético, as archaeas também se assemelham muito mais aos eucariotos que às bactérias. A maquinaria de transcrição em Archaea é semelhante aos sistemas dos eucariotos em termos da estrutura e função da RNA polimerase, no entanto esta depende de um conjunto mínimo de fatores de transcrição e elementos relacionados aos promotores (Grohmann \& Werner, 2011). Além disso, já foi descrita a resistência da RNA polimerase de archaeas a antibióticos frequentemente utilizados contra bactérias, evidenciando suas diferenças estruturais (Sturm et al., 1980).

Quando a denominação Archaea foi proposta, os autores também propuseram que este domínio era composto por dois filos, Euryarchaeota e Crenarchaeota, os quais são até hoje formalmente aceitos (Woese et al., 1990). O filo Euryarchaeota é bastante heterogêneo, apresentando organismos com fisiologias bem distintas. Organismos metanogênicos, halófilos, redutores de sulfato e alguns hipertermófilos podem ser encontrados nesse filo. $\mathrm{O}$ filo Crenarchaeota foi inicialmente sugerido como mais ancestral e caracterizado como relativamente homogêneo, abrangendo muitos organismos hipertermófilos. Posteriormente, com a crescente detecção de sequências de DNA de Archaea em vários ambientes, foi proposto que o filo Crenarchaeota também englobaria um grupo de archaeas mesófilas, denominado Grupo I, o qual apresentava três subgrupos - I.1a, I.1b e I.1c - de acordo com a afiliação das sequências em árvores filogenéticas (DeLong, 1998). 
Atualmente, a classificação filogenética das archaeas é tema de muitas discussões na literatura e propostas para a criação de novos filos vêm sendo feitas com base em novas sequências identificadas e análises moleculares mais refinadas.

O filo Korarchaeota foi proposto a partir de análises de sequências do gene do rRNA 16S obtidas de amostras de fontes termais do Parque Nacional de Yellowstone, nos Estados Unidos (Barns et al., 1996). As análises sugeriram que as sequências encontradas não se assemelhavam àquelas de organismos dos filos Crenarcheota ou Euryarcheota e que se situavam numa posição basal na árvore filogenética, antes da bifurcação desses dois filos. Embora nenhum representante deste filo tenha sido obtido em cultura pura em meios artificiais até o momento, o genoma completo de um organismo, denominado "Candidatus Korarchaeum cryptofilum", foi recentemente sequenciado e poderá contribuir para a aceitação formal deste filo (Elkins et al., 2008).

Organismos encontrados em uma fenda hidrotermal na Islândia, de caráter simbionte e dimensões diminutas, levaram à proposta de um novo filo denominado Nanoarcheota, por apresentarem sequências de rRNA muito diferentes daquelas dos demais filos, não sendo amplificadas em reações de PCR com iniciadores até então considerados universais para o domínio Archaea (Huber et al., 2003). Essa archaea foi denominada Nanoarchaeum equitans e sempre encontrava-se fortemente associada à outra espécie de archaea, Ignicoccus hospitalis, não apresentando crescimento na sua ausência. Posteriormente, no entanto, outros estudos questionaram a criação do novo filo, sugerindo por meio de análises comparativas de proteínas ribossomais que esse organismo representaria uma linhagem de rápida evolução do filo Euryarcheota (Brochier et al., 2005).

Em 2008 foi proposta a criação do filo Thaumarcheota, que seria constituído por archaeas previamente descritas como crenarcheotas, mas que apresentavam natureza mesofílica (Brochier-Armanet et al., 2008). Tal proposta levava em consideração a análise comparativa de proteínas ribossomais e indicava que membros do Grupo I de Crenarcheota formavam na realidade um filo a parte. Membros deste filo foram identificados em diversos tipos de ecossistemas terrestres e aquáticos, inclusive em fontes termais (Walker et al., 2010; Lehtorvirta-Morley et al., 2011, Pester et al., 2011), evidenciando sua diversidade fenotípica.

Posteriormente, a montagem de uma biblioteca genômica da comunidade microbiana de uma fonte geotermal do subsolo de uma mina de ouro possibilitou a reconstrução do genoma da archaea "Candidatus Caldiarchaeum subterraneum" (Nunoura et al., 2011). Os autores defendiam que o genoma apresentava características únicas distintas de todos os filos aceitos e propostos de archaea até o momento, incluindo um sistema do tipo ubiquitina 
semelhante ao dos eucariotos e tais aspectos justificariam a proposta de mais um filo: o Aigarcheota (Nunoura et al., 2011). No entanto, a proposta de criação deste novo filo foi questionada por Brochier-Armanet e colaboradores (2011), que baseando-se em análises de proteínas ribossomais, sugeriram que $C$. subterraneum compartilha características com Thaumarcheota e representaria uma ordem localizada na base da ramificação deste filo na árvore filogenética.

Mais recentemente, uma abrangente inferência filogenética de archaeas e bactérias foi realizada utilizando genomas obtidos de diversos ambientes pela técnica de sequenciamento do genoma de células únicas (single-cell genomics) e análises de diversas sequências de genes de rRNA ribossomal de representantes de filos candidatos dos dois domínios (Rinke et al., 2013). De acordo com os autores, as árvores filogenéticas construídas a partir de vários genes marcadores concatenados permitiram uma identificação robusta das associações entre os diferentes filos e suportariam a proposta de quatro novos filos no domínio Archaea: Diapherotrites, Parvarchaeota, Aenigmarchaeota e Nanohaloarchaeota. Além disso, de acordo com as análises realizadas por esses autores, os filos Nanoarchaeota e Aigarchaeota, cujas propostas vinham sendo questionadas por alguns grupos, deveriam ser mantidos. Outra questão levantada neste trabalho foi o agrupamento da maioria dos filos de archaea (com exceção do filo Euryarchaeota, que formaria um ramo a parte) em dois superfilos: o superfilo TACK, composto por Thaumarchaeota, Aigarchaeota, Crenarchaeota, Korarchaeota e o superfilo DPANN, constituído pelos filos Diapherotrites, Parvarchaeota, Aenigmaarchaeota, Nanoarchaeota e Nanohaloarchaeota (Figura 1). 


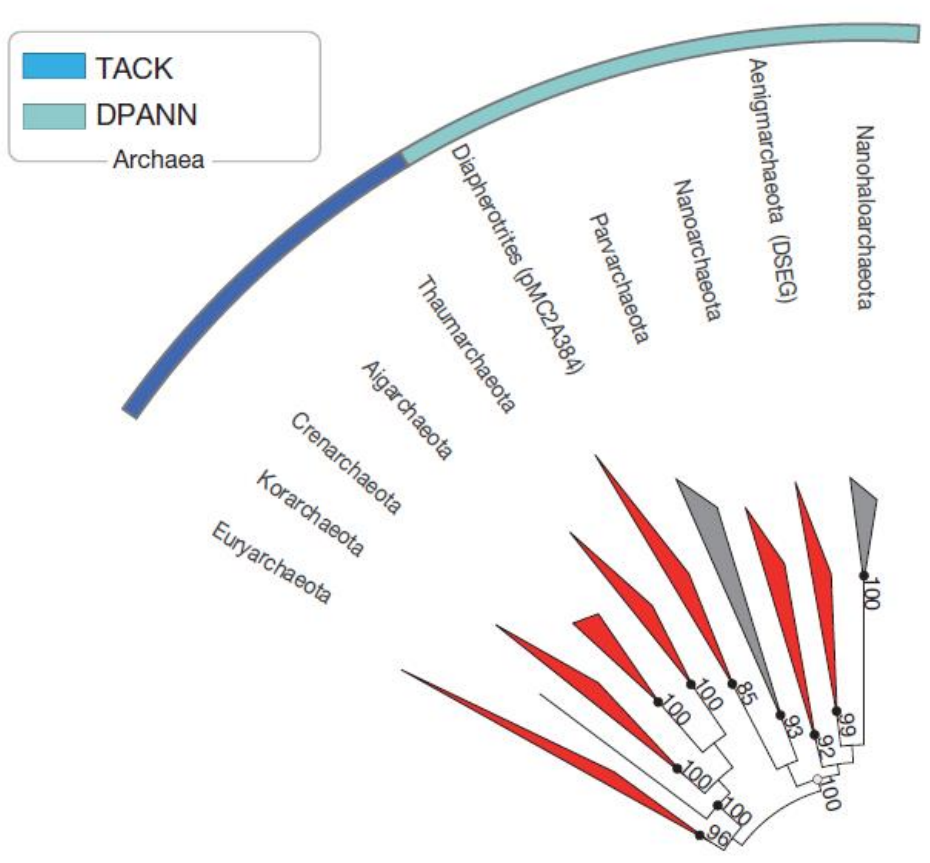

Figura 1. Árvore filogenética de Archaea a nível de filo, construída a partir de 38 genes marcadores concatenados. Os superfilos propostos TACK e DPANN estão indicados. Retirado de Rinke et al., 2013.

\subsection{Ubiquidade de Archaea}

Os primeiros microrganismos a serem reconhecidos como pertencentes ao domínio Archaea, e não ao Bacteria como acreditava-se anteriormente, foram aqueles com a capacidade de reduzir o dióxido de carbono a metano, conhecidos como metanogênicos (Fox et al., 1977). Estudos posteriores mostraram que várias outras espécies previamente classificadas como bactérias termoacidófilas, halófilas ou oxidantes de enxofre também pertenciam, na realidade, ao domínio Archaea (Magrum et al., 1978; Woese et al., 1978). Por esse motivo, as archaeas foram então por muito tempo associadas apenas a locais com ausência de oxigênio, altas temperaturas e extremos de $\mathrm{pH}$ ou salinidade, fazendo com que esses ambientes fossem alvos de muitos estudos relacionados a membros deste domínio (Darland et al., 1970; Balch et al., 1979; Fiala \& Stetter, 1986; Mathrani et al., 1988; Barns et al., 1994; Blochl et al., 1997) e levando à crença que apenas seres extremófilos o compunham.

No entanto, com a crescente utilização de abordagens moleculares para o estudo de comunidades microbianas, no início da década de 90 esse conceito começou a ser modificado, pois trabalhos independentes dos grupos de DeLong (1992) e Fuhrman (1993) detectaram, 
por meio de sondas e iniciadores específicos para o domínio Archaea, a presença de membros dos filos Crenarchaeota e Euryarchaeota em águas costeiras marinhas. Tal relato foi surpreendente, já que até aquele momento só haviam sido descritas crenarchaeotas com crescimento ótimo a temperaturas superiores a $80^{\circ} \mathrm{C}$. Posteriormente, dando continuidade a seus estudos, DeLong e colaboradores (1994) observaram a ubiquidade de archaeas em águas costeiras da Antártica, demonstrando sua presença em ambientes frios.

Nos anos seguintes, muitos trabalhos relataram e seguem relatando a ampla distribuição das archaeas em diferentes ambientes terrestres e aquáticos mesófilos, assim como em ambientes extremos (Delong, 1998; Chaban et al., 2006). Archaeas já foram detectadas em diversos solos (Bintrim et al., 1997; Sliwinski \& Goodman, 2004; Timonen \& Bomberg, 2009), lagoas de água doce (Vissers et al., 2009), ecossistemas marinhos (Wuchter et al., 2006; Silveira et al., 2013), sedimentos (Glissman et al., 2003; Rodrigues et al., 2014), estações de tratamento de esgoto (Gray et al., 2002) e até em diversas partes do corpo humano (Eckburg et al., 2003; Horz \& Conrads, 2010; Dridi et al., 2011), entre outros ambientes. Hoje em dia, considera-se que a distribuição de archaeas no ambiente seja equivalente à bacteriana.

As sequências de archaeas identificadas em ambientes não extremos foram inicialmente afiliadas aos filos Crenarchaeota e Euryarchaeota, sendo o Grupo I pertencente ao primeiro filo e os Grupos II e III ao segundo (DeLong, 1998). No entanto, análises subsequentes indicaram que sequências de archaeas mesófilas do Grupo I formavam um grupo irmão, não monofilético com as crenarchaeotas hipertermófilas (Robertson et al., 2005). Posteriormente, a partir do primeiro genoma sequenciado de um membro do Grupo I (Hallam et al., 2006) e baseando-se em árvores filogenéticas construídas a partir de proteínas ribossomais, Brochier-Armanet e colaboradores (2008), propuseram que o Grupo I fosse considerado um filo a parte, denominando-o Thaumarchaeota.

Atualmente sabe-se que membros deste filo proposto constituem uma das mais abundantes e diversificadas linhagens de archaea, tendo sido identificados em diversos tipos de ecossistemas terrestres e aquáticos, inclusive em fontes termais, apresentando assim representantes mesófilos e termófilos (Brochier-Armanet et al., 2011). Do ponto de vista ecológico, o filo Thaumarchaeota vem recebendo muita atenção desde a descoberta de que alguns de seus membros realizam a oxidação aeróbica de amônia, um metabolismo que acreditava-se estar restrito apenas a bactérias dos grupos beta-Proteobacteria e gammaProteobacteria (Schleper \& Nicol, 2010). 


\subsection{Archaeas oxidantes de amônia (AOAs)}

A oxidação de amônia é o primeiro passo da nitrificação, que consiste na conversão da amônia a nitrato, um ponto fundamental do ciclo biogeoquímico do nitrogênio. A nitrificação é um processo que pode ser dividido em duas etapas. A primeira etapa é a oxidação da amônia a nitrito, mediada pela enzima amônia monoxigenase e a segunda etapa envolve a oxidação do nitrito a nitrato pela enzima nitrito oxido-redutase (Canfield et al., 2010). A oxidação de amônia é muitas vezes a etapa limitante da nitrificação em uma variedade de ambientes, sendo portanto uma reação crítica no ciclo do nitrogênio (You et al., 2009). Além disso, é uma reação essencial em ecossistemas agriculturáveis, já que estes recebem grandes quantidades de fertilizantes, em sua maioria com o nitrogênio em forma de amônia, que deve então ser oxidada para o prosseguimento do ciclo (Jia \& Conrad, 2009).

Apesar de pertencerem a dois domínios distintos, tanto as archaeas oxidantes de amônia (AOAs) quanto as bactérias oxidantes de amônia (AOBs) utilizam enzimas amônia monoxigenases (AMO) homólogas (Pester et al., 2012), mas se sabe que existem algumas diferenças no processo da oxidação de amônia realizado por estes organismos. Por exemplo, a AMO de archaeas apresenta uma maior afinidade ao substrato do que a AMO de bactérias e as AOBs são autótrofas obrigatórias, enquanto as AOAs também podem utilizar fontes de carbono orgânico (Zhalnina et al., 2012).

Desde a sua descoberta, muitos trabalhos vêm relatando a presença de AOAs em diversos ambientes, como solos (Ying et al., 2010; Gubry-Rangin et al., 2011; Zhang et al., 2010), água marinha (Könneke et al., 2005; Wuchter et al., 2006), sedimentos marinhos (Francis et al., 2005; Beman \& Francis, 2006), aquários e fontes de água doce (Sauder et al., 2011; Peng et al., 2013), biorreatores de tratamento de esgoto (Park et al., 2006), fontes termais (Weidler et al., 2007), entre outros. Além disso, a predominância de AOAs em relação às $\mathrm{AOBs}$ em certos ambientes também vem sendo sugerida, principalmente em alguns solos (Leininger et al., 2006; Nicol et al., 2008). Assim, as AOAs podem ter um papel essencial na nitrificação, e consequentemente no ciclo global do nitrogênio, e a importância de se estudar melhor sua fisiologia vem sendo constantemente ressaltada por muitos grupos de pesquisa.

Devido a acessibilidade e facilidade, muitos trabalhos vêm empregando metodologias moleculares para a obtenção de informações sobre a distribuição e abundância das AOAs nos diferentes ambientes. A detecção do gene que codifica a subunidade alfa da enzima amônia monoxigenase $(a m o A)$ de archaeas é a abordagem mais amplamente utilizada, por se tratar de 
um marcador filogenético e funcional deste grupo (Pester et al., 2012). Desta forma, o número de trabalhos que identificam sequências do gene amoA em vários ambientes vem aumentando e trazendo mais informações sobre a filogenia, ocorrência e distribuição das archaeas com potencial para a oxidação de amônia em diferentes condições. No entanto, devido às muitas dificuldades relacionadas ao cultivo em laboratório, existe até o momento a descrição de apenas três AOAs obtidas em culturas puras (Könneke et al., 2005; Tourna et al., 2011; Lehtorvita-Morley et al., 2014) e poucas culturas de enriquecimento obtidas a partir de ambientes terrestres e aquáticos (Hatzenpichler et al., 2008; Blainey et al., 2011; Jung et al., 2011), fazendo com que os estudos sobre a fisiologia e metabolismo dos organismos deste grupo sejam limitados e muitos aspectos ainda desconhecidos.

\subsection{Importância do cultivo laboratorial de microrganismos}

A dificuldade de se cultivar microrganismos ambientais em laboratório é conhecida entre os microbiologistas há muito tempo e, em 1985, Staley e Konopka cunharam um termo para descrever a diferença entre a diversidade microbiana observada nos ambientes naturais e a quantidade de microrganismos cultiváveis em meios artificiais - a "grande anomalia da contagem em placas". Os autores relataram que há uma discrepância de várias ordens de grandeza entre o número de organismos de amostras ambientais quantificados por contagens microscópicas diretas e o número de colônias observadas em meios artificiais, ou seja, o número de células viáveis. Tal fenômeno já vinha sendo observado por muitas décadas e reflete a baixa eficiência na obtenção de microrganismos ambientais viáveis em cultivos laboratoriais.

Dados de Amman et al. (1995) sugeriam que somente 0,001 a $0,1 \%$ dos microrganismos marinhos e $0,3 \%$ de microrganismos do solo quantificados por contagem direta era cultivável, e estudos posteriores de Torsvik e colaboradores (2002) relataram que apenas $1 \%$ da diversidade microbiana descrita em nosso planeta tinha representantes cultivados. Por esse motivo, durante muito tempo o estudo da microbiologia se encontrou limitado, já que a identificação microbiana e a análise de sua diversidade dependiam do isolamento dos microrganismos em culturas puras.

No entanto, a partir da década de 80 , tal cenário começou a mudar. Os métodos moleculares, independentes de cultivo, passaram a ser amplamente utilizados nos estudos de comunidades microbianas, possibilitando assim a identificação de milhares de microrganismos sem a necessidade da obtenção de culturas e reforçando a noção de que as 
espécies não cultiváveis correspondem à principal fração da diversidade microbiana de nosso planeta (Handelsman, 2004). Durante anos, acreditou-se que as análises moleculares permitiriam a superação das limitações nos estudos microbiológicos impostos pelas dificuldades no estabelecimento de culturas laboratoriais e diversos trabalhos passaram a ter, e ainda têm, esse enfoque (Rondon et al., 1999; Torsvik \& Øvreas, 2002; Streit \& Schimitz, 2004; Tringe et al., 2005; Sogin et al., 2006; Delmont et al., 2011).

No entanto, embora as técnicas de biologia molecular tenham contribuído de forma significante para a ecologia e filogenia microbiana e avanços na área da biotecnologia tenham sido feitos utilizando-se esses métodos, o cultivo dos microrganismos ainda é imprescindível para o entendimento de diversos aspectos da sua biologia e de suas relações intra- e interespecíficas. A importância do estabelecimento de culturas laboratoriais de microrganismos ambientais vem sendo enfatizada cada vez mais, sendo que debates relacionados às dificuldades associadas ao cultivo e propostas de soluções para superá-las têm sido feitos por alguns autores (Zengler et al., 2002; Alain \& Querellou, 2009).

Watve e colaboradores (2000) propuseram que os ambientes terrestres e aquáticos provavelmente possuem muitos microrganismos oligotróficos e que sua transferência para os meios laboratoriais, ricos em nutrientes, gera um impacto metabólico que pode inibir seu crescimento. Propostas sugerindo a utilização de meios que possuam os componentes existentes nos ambientes naturais são cada vez mais frequentes e culturas de microrganismos que nunca haviam sido cultivados antes puderam ser estabelecidas em laboratório utilizandose métodos que mimetizavam essas condições nutricionais (Connon \& Giovannoni, 2002; Rappé et al., 2002; Gavrish et al., 2008). Neste sentido, Kaeberlein e colaboradores (2002) fizeram uma grande contribuição para o cultivo de microrganismos marinhos, sugerindo a montagem de sistemas denominados câmaras de difusão. Esses dispositivos possuíam membranas com poros cujo tamanho permitiam a troca de nutrientes, mas não a passagem de microrganismos. A amostra ambiental era colocada entre as membranas e a câmara de difusão era então submersa em um aquário contendo sedimentos e água provenientes do mesmo local da amostra. Tal técnica permitiu o cultivo de vários microrganismos não cultivados anteriormente e enfatizou a importância das condições naturais no estabelecimento bem sucedido de culturas laboratoriais.

Em relação às archaeas especificamente, as dificuldades envolvendo seu cultivo vêm sendo reportadas na literatura com frequência (Schleper et al., 2005; Vartoukian et al., 2010; Leigh et al., 2011). Um artigo recente relata que, até 2010, apenas cerca de 60 espécies de archaeas haviam sido cultivadas em meios artificiais (Auguet et al., 2010). As archaeas 
extremófilas, por serem conhecidas há mais tempo e demandarem condições de crescimento mais específicas, representam a maioria das espécies obtidas em culturas puras até hoje. Alguns artigos relatam o isolamento e cultivo de archaeas halófilas, termoacidófilas e metanogênicas (Balch et al., 1979; Mathrani et al., 1988; Tsao et al., 1994; Burns et al., 2004; Kuwabara et al., 2007; Pikuta et al., 2007; Andrei et al., 2012; Luque et al., 2012). No entanto, o cultivo de archaeas de ambientes terrestres e aquáticos mesófilos continua sendo um desafio, com poucos relatos na literatura (Könneke et al., 2005; Simon et al., 2005; Tourna et al., 2011; Kim et al., 2012; Lehtorvita-Morley et al., 2014) e muitas vezes consistindo de co-cultivos entre archaeas e bactérias. Se compararmos o número de sequências de DNA de archaeas depositadas em bancos de dados com o número de organismos deste domínio cultivados até hoje, a dificuldade no estabelecimento de cultivos laboratoriais fica ainda mais evidente, já que existem, mais de 250.000 sequências de rDNA 16S depositadas nesses bancos.

Assim, as técnicas moleculares são muito importantes e facilitam imensamente os estudos de ecologia microbiana e o acesso à diversidade dos microrganismos presentes nos diferentes ambientes, mas o cultivo dos microrganismos em laboratório ainda é imprescindível para o entendimento de vários aspectos da sua biologia e até para a descoberta de possíveis potenciais biotecnológicos. Desta forma, trabalhos que visem o cultivo laboratorial das bactérias e archaeas dos mais variados ambientes são fundamentais para avanços nos estudos da microbiologia.

\subsection{O bioma Cerrado}

Em termos de extensão, o Cerrado é o segundo maior bioma do Brasil, cobrindo uma área aproximada de 2 milhões de quilômetros quadrados, o que representa cerca de $22 \%$ do território nacional (Oliveira-Filho \& Ratter, 2002). Este bioma está localizado na região do Planalto Central do Brasil e caracteriza-se pela presença de duas estações bem definidas, a seca (de maio a setembro) e a chuvosa (de outubro a abril), com uma precipitação média anual de 1500mm (Klink \& Machado, 2005). Devido ao grande número de espécies endêmicas deste bioma e à crescente degradação de seus habitats naturais, o Cerrado é considerado um hotspot de biodiversidade e esforços para conservação (Myers et al., 2000).

A vegetação do Cerrado é constituída de um mosaico de diferentes fitofisionomias que compreendem formações florestais, savânicas e campestres. Assim, existem áreas com predomínio de um estrato arbóreo com formação de dossel contínuo ou descontínuo, áreas 
que apresentam estrato arbóreo-arbustivo e ainda aquelas aonde o estrato herbáceo é predominante (Ribeiro \& Walter, 1998). Segundo Eiten (1994), os fatores que determinam as formas fisionômicas são a fertilidade e o teor de alumínio disponível no solo, a profundidade do solo e o grau de saturação da camada superficial ou subsuperficial do solo.

Ribeiro e Walter (1998) apresentaram uma extensa revisão das características da vegetação do cerrado, sugerindo uma classificação detalhada e propondo a divisão do cerrado em onze diferentes fitofisionomias e algumas subdivisões. O Cerrado sensu stricto é a fitofisionomia mais característica e mais comum do bioma. Sua vegetação é composta por espécies arbóreas e rasteiras, com árvores lenhosas de aspecto retorcido, casca grossa e folhas rígidas (Eiten, 1994). Em sua forma mais típica um estrato arbustivo-arbóreo predomina, com cobertura de copas entre 20 e 50\% possuindo uma altura média de três a seis metros, e há um estrato herbáceo de densidade variável (Ribeiro \& Walter, 1998). O Cerrado sensu stricto, além desta vegetação típica, pode apresentar subtipos que são denominados Cerrado Denso e Cerrado Ralo, de acordo com a estrutura do estrato arbóreo-arbustivo, ou ainda Cerrado Rupestre, que diferencia-se pelo solo mais raso com a presença de afloramentos de rochas (Ribeiro \& Walter, 1998).

As queimadas são comuns no cerrado. Estas podem ser de origem natural - iniciadas por descargas elétricas - ou causadas por ação humana e existem relatos de sua ocorrência em regiões de cerrado há milhares de anos (Miranda et al., 2002). Assim, o fogo, juntamente com os fatores já mencionados, pode ser considerado um determinante da vegetação do Cerrado (Eiten, 1994). As queimadas também têm grande importância ecológica no cerrado, especialmente na ciclagem de nutrientes, já que a vegetação apresenta baixo conteúdo de nutrientes, a taxa de decomposição da serapilheira é baixa e os solos são pobres (Miranda et al., 2002). Além disso, várias espécies de plantas do estrato herbáceo parecem depender do fogo para sua reprodução, com intensa floração sendo observada poucos dias ou semanas após a passagem do fogo (Coutinho, 1976; Oliveira et al., 1996). Tal fato pode estar relacionado a alterações no microclima local, aumento na produtividade após a passagem do fogo e também ao dano causado na parte área da vegetação (Miranda et al., 2004).

No entanto, os impactos do fogo sobre o sistema vão depender do tipo e regime de queima. O regime de queima é caracterizado pela época e frequência da queima e pouco se sabe ainda sobre o regime de incêndios de origem natural no Cerrado. Trabalhos de França e colaboradores (2007) e Ramos-Neto e Pivello (2000) avaliaram a ocorrência de incêndios naturais em áreas de cerrado em parques nacionais e seus resultados indicam que a maioria das queimadas naturais (iniciadas por raios) ocorrem na estação chuvosa, geralmente 
extinguidas pela chuva logo após seu início, e nos meses de transição entre as estações, quando podem ocorrer queimadas mais intensas e que atingem áreas mais extensas. Além disso, os resultados obtidos pelos autores permitiriam inferir que a frequência de incêndios naturais no Cerrado pode variar de 1 a mais de 9 anos, dependendo da fitofisionomia considerada. Porém, com a rápida ocupação das regiões de Cerrado nos últimos anos, as queimadas passaram a ser realizadas para o manejo da terra, principalmente durante a estação seca, com uma frequência que varia entre 1 e 4 anos (Miranda et al., 2010). Atualmente, a agricultura é a principal causa de incêndios no Cerrado, com o fogo sendo utilizado para a abertura e limpeza de extensas áreas para o plantio ou para o manejo de pastagens naturais ou plantadas (Coutinho, 1990). Desta forma, a ação humana vem modificando o regime de queima nas áreas deste bioma, com consequências para a composição e estrutura da vegetação. Estudos indicam que queimadas frequentes em áreas de Cerrado sensu stricto, realizadas em um regime bienal na época seca, causam uma alta taxa de mortalidade de espécies lenhosas e alterações nas suas taxas de regeneração, levando à redução da densidade de vegetação lenhosa e ao consequente surgimento de fisionomias mais abertas nestas áreas, com predominância de gramíneas no estrato herbáceo (Sato \& Miranda, 1996; Moreira, 2000).

O Cerrado sensu stricto desenvolve-se sobre latossolos, solos em avançado estado de intemperismo, geralmente bem drenados, profundos e de baixa fertilidade. São forte ou moderadamente ácidos, com baixos teores de bases $(\mathrm{Ca}, \mathrm{Mg}$ e $\mathrm{K}$ ) e fósforo disponíveis para as plantas e apresentam altos níveis de alumínio (Haridasan, 1994).

Solos apresentam grande diversidade e abundância de microrganismos, existindo estimativas que um grama de solo pode conter bilhões de microrganismos de milhares de espécies (Torvsk \& Øvreas, 2002). O solo é um sistema estruturado, heterogêneo e descontínuo, apresentando diversos microhabitats com diferentes características que podem favorecer o desenvolvimento de várias comunidades microbianas nativas (Nannipieri et al., 2003), com representantes dos três domínios da vida - Bacteria, Archaea e Eukaya. As archaeas são amplamente distribuídas em solos, tendo sido identificadas sequências de rRNA 16S de organismos deste domínio em solos de todos os continentes (Schleper et al., 2005). De forma geral, há estimativas de que as archaeas representam de 1 a $2 \%$ dos procariotos de solos moderados aeróbicos (Buckley et al., 1998), e trabalhos relataram que sequências de archaea chegavam a representar 5\% em solos arenosos (Ochsenreiter et al., 2003) e até 38\% em solos ácidos de floresta (Kemnitz et al., 2007).

Quanto aos microrganismos dos solos de Cerrado, existem alguns trabalhos acerca da riqueza e diversidade de fungos e bactérias, como o de Castro e colaboradores (2008) que 
descreveram a comunidade de fungos em solos de Cerrado sensu stricto, Mata de Galeria e também em áreas de Cerrado transformadas em pastagens e cultivo de soja. Bresolin e colaboradores (2010) compararam as comunidades fúngicas e bacterianas de solos sob Cerrado nativo e sob monoculturas de soja. Outros trabalhos avaliaram as comunidades bacterianas em solos de diferentes fitofisionomias do Cerrado e de áreas de Cerrado convertidas em pastagem ou sob diferentes usos e manejos (Quirino et al., 2009; Araújo et al., 2012; Silva, 2012). No entanto, são escassas as informações acerca das archaeas em solos de cerrado, existindo apenas um trabalho que teve como objetivo a descrição da comunidade de archaeas em solos de Cerrado Denso e Mata de Galeria, realizado por Catão e colaboradores (2013). Além disso, apesar dos muitos relatos de archaeas oxidantes de amônia em solos de diversos ecossistemas (Ying et al., 2010; Gubry-Rangin et al., 2011; Pester et al., 2012), ainda não existem estudos sobre a ocorrência de archaeas com este potencial em solos do bioma Cerrado.

Outro aspecto ainda pouco abordado na literatura consiste no estudo sobre a composição da comunidade microbiana em solos de áreas de Cerrado frequentemente submetidas a queimadas e áreas protegidas do fogo por longos períodos, ponto importante a ser avaliado, já que o regime de queima é um fator importante na estruturação e dinâmica do Cerrado. Estudos de Nardoto e Bustamante (2003) e Viana e colaboradores (2011) analisaram diferenças na biomassa microbiana e no perfil de lipídeos bacterianos entre amostras de solo de áreas submetidas ou não a um regime de queima frequente, no entanto não existem estudos que caracterizem filogeneticamente os microrganismos nestes solos. Assim, não se tem informações sobre a comunidade de archaeas nos solos de Cerrado submetidos a essas condições (proteção do fogo ou queimadas periódicas).

Tendo em vista o exposto acima, essa dissertação teve como objetivo a descrição de comunidades de archaea de solo de duas áreas de Cerrado sensu stricto: uma submetida a queimadas frequentes e outra protegida do fogo por um longo período. Além disso, tendo em vista a necessidade da obtenção de archaeas mesófilas em cultivo para que sua biologia e potencial biotecnológico sejam melhor entendidos, este trabalho também visou a obtenção de culturas de archaea de solo de Cerrado por meio da confecção de meios de cultura que mimetizam as condições nutricionais encontradas no ambiente natural. 


\section{Objetivos}

\subsection{Objetivo geral}

Analisar e descrever a comunidade de archaeas em solos de Cerrado sensu stricto por meio de análises comparativas de genes de rRNA $16 \mathrm{~S}$ e amoA e de cultivo em meios artificiais.

\subsection{Objetivos específicos}

- Caracterizar a riqueza de archaeas de solos de Cerrado sensu stricto;

- Avaliar e comparar a comunidade de archaeas de solo de Cerrado sensu stricto de uma área submetida a um regime de queima bienal e outra protegida do fogo há mais de 15 anos, analisando um possível efeito das queimadas frequentes nestas comunidades;

- Detectar a ocorrência de archaeas com o potencial para a oxidação de amônia nos solos de Cerrado sensu stricto submetidos ou não a queimadas frequentes;

- Estabelecer o cultivo de archaeas do solo de Cerrado sensu stricto por meio da confecção de meios de cultura seletivos a partir de suspensões do solo; 


\section{Material e Métodos}

\subsection{Coleta dos solos}

As amostras de solo foram coletadas no dia 02 de setembro de 2013, na Reserva Ecológica do Instituto Brasileiro de Geografia e Estatística (RECOR-IBGE), localizada a 35 $\mathrm{km}$ ao sul do centro de Brasília na BR 251 (15 55' S, 47 51' W). A RECOR pertence à Área de Proteção Ambiental (APA) Distrital Gama-Cabeça de Veado.

O solo foi coletado em duas diferentes áreas de Cerrado sensu stricto pertencentes ao Projeto Fogo, coordenado pela Prof. Dr. Heloísa Sinátora Miranda, do Departamento de Ecologia da Universidade de Brasília. A primeira área, protegida do fogo há mais de 15 anos, foi denominada área Controle, enquanto a segunda área, denominada Queimada, era submetida a um regime de queima bienal desde 1992 (Figura 2). O regime de queima empregado nesta área consistia no bienal modal, ou seja, as queimadas controladas eram realizadas de dois em dois anos, sempre no meio da estação seca (início de agosto). A última queimada realizada nesta área foi em agosto de 2011. O solo foi amostrado em triplicatas em ambas as áreas, sendo estas coletadas a uma distância de aproximadamente um metro entre si. As amostras foram coletadas na faixa de 0 a $10 \mathrm{~cm}$ de profundidade e foram estocadas a $-20^{\circ} \mathrm{C}$. Também foi coletado solo de um ponto em cada área para a avaliação de seus parâmetros físico-químicos pela empresa SOLOQUÍMICA Análises de Solo LTDA.
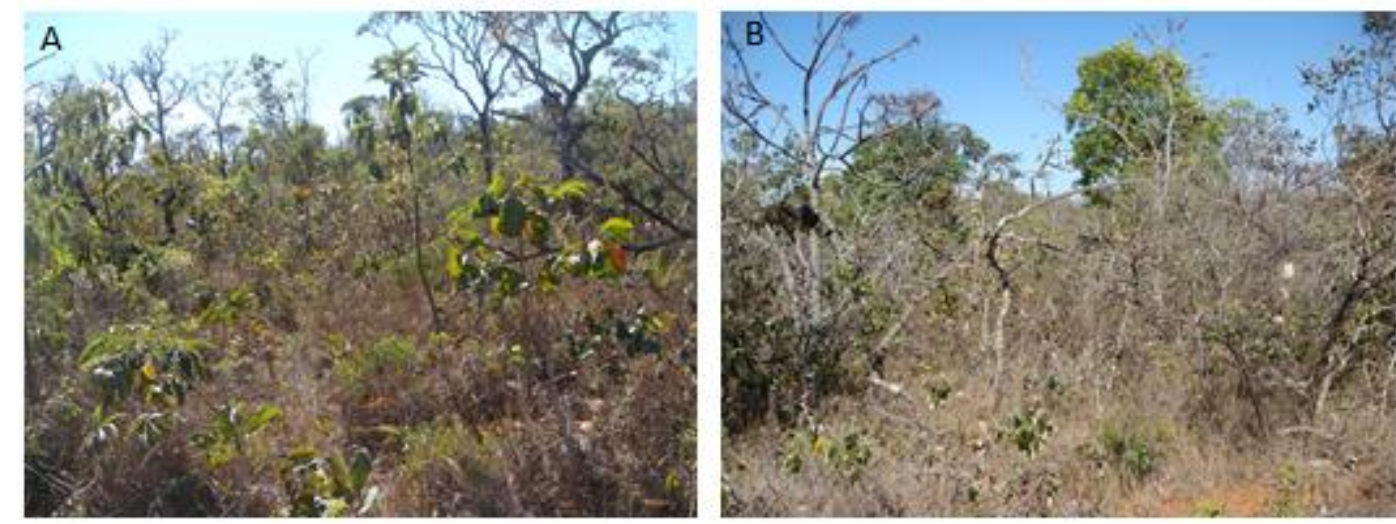

Figura 2. Fotos das áreas de Cerrado sensu stricto onde foram coletadas as amostras de solo. Em A, área Controle, que não sofria queimadas há mais de 15 anos e em $\mathbf{B}$ área Queimada, submetida a queimadas bienais.

Em 29 de janeiro de 2014, foi coletado solo na área Controle, protegida do fogo há mais de 15 anos, para a confecção dos meios de cultura utilizados para o estabelecimento do 
cultivo de archaeas a partir de um inóculo de solo dessa mesma área. O solo também foi coletado na faixa de 0 a $10 \mathrm{~cm}$ de profundidade e uma parte da amostra de solo foi enviada para a avaliação de seus parâmetros físico-químicos pela mesma empresa. O solo utilizado para a posterior confecção dos meios foi estocado a $4^{\circ} \mathrm{C}$.

\subsection{Confecção dos meios de cultura, inóculo inicial e manutenção das culturas}

Para o preparo de meio sólido, o solo foi homogeneizado em água destilada (concentração final de $5 \%-\mathrm{p} / \mathrm{v}$ ) e mantido em repouso por 5 a 10 minutos para permitir a deposição das partículas maiores. Em seguida, o sobrenadante foi coado em coador de papel, transferido para um novo frasco, acrescido de ágar (concentração final de $2 \%$ - p/v) e esterilizado em autoclave. Para o preparo de meio líquido, o coado foi filtrado em membranas com poros de $0,22 \mu \mathrm{m}$, a fim de se retirar partículas maiores que tenham passado pelo coador e de esterilizar o meio. Os seguintes agentes antimicrobianos (antibióticos e antifúngicos) foram adicionados aos meios de maneira sucessiva, visando a eliminação de bactérias e fungos: ampicilina $(150 \mu \mathrm{g} / \mathrm{ml})$, estreptomicina $(50 \mu \mathrm{g} / \mathrm{ml})$, cloranfenicol $(20 \mu \mathrm{g} / \mathrm{ml})$, bacitracina $(250 \mu \mathrm{g} / \mathrm{ml})$, norfloxacina $(200 \mu \mathrm{g} / \mathrm{ml})$, itraconazol $(0.25 \mathrm{mg} / \mathrm{ml})$ e cetoconazol $(30 \mu \mathrm{g} / \mathrm{ml})$.

O inóculo inicial foi obtido a partir da mistura do solo em água destilada estéril (concentração final de $20 \%$ - p/v) deixada em repouso por 2 a 5 minutos para a deposição de partículas maiores. Diferentes volumes do sobrenadante $(50,75$ e $100 \mu \mathrm{l})$ foram inoculados em placas de Petri contendo meio sólido acrescido de agentes antimicrobianos. Diluições seriadas do inóculo inicial $(1 / 10,1 / 100,1 / 1000$ e 1/10000) foram preparadas em meio líquido e, após duas semanas de incubação a $28^{\circ} \mathrm{C}$, alíquotas de 20,50 e $100 \mu \mathrm{l}$ das culturas foram semeadas no meio sólido. As placas de cultura foram mantidas em estufa a $28^{\circ} \mathrm{C}$ e repicadas aproximadamente uma vez por mês. Os tubos de cultura em meio líquido resultantes das diluições também foram mantidos na estufa a $28^{\circ} \mathrm{C}$, no entanto não foi observado crescimento em meios líquidos.

\subsection{Coloração de Gram das células do cultivo e visualização por microscopia óptica}

Após vários meses de manutenção das culturas, esfregaços a partir dos diferentes tipos coloniais observados nos meios de cultura foram realizados sobre lâminas histológicas de vidro, com o auxílio de alça de níquel-cromo. Os esfregaços foram então secos e fixados no 
fogo e, posteriormente, submetidos à coloração diferencial de Gram. Em resumo, o esfregaço foi recoberto com cristal violeta por 1 minuto e após esse tempo o excesso do corante foi lavado com água destilada. Em seguida, o esfregaço foi coberto com lugol por mais 1 minuto, lavado com água destilada e coberto com etanol absoluto por 10 a 15 segundos. Por último, o corante fucsina foi colocado sobre os esfregaços por 1 a 2 minutos e, após esse tempo, o excesso foi retirado por lavagem com água destilada. Após a secagem das lâminas, estas foram visualizadas em aumentos de 630 ou 1000X e fotografadas no microscópio de luz Axiophot (Zeiss, Alemanha) gentilmente disponibilizado pelo grupo da Prof. Sônia Nair Báo, do Laboratório de Microscopia da Unb.

\subsection{Visualização por Microscopia Eletrônica de Varredura (MEV)}

A preparação e análise das amostras de células de diferentes tipos coloniais por microscopia eletrônica de varredura foram realizadas no Laboratório de Microscopia da Universidade de Brasília, coordenado pela professora Sônia Nair Báo. As células foram retiradas das placas de cultivo, lavadas em tampão salina-fosfato (PBS) $1 \mathrm{X}$ ( $\mathrm{NaCl} 137 \mathrm{mM}$, $\mathrm{KCl} 2,7 \mathrm{mM}, \mathrm{Na}_{2} \mathrm{PO}_{4} 8,1 \mathrm{mM}, \mathrm{KH}_{2} \mathrm{PO}_{4} 1,5 \mathrm{mM}$ ) e fixadas em fixador Karnovisky 0,1M (paraformaldeido $2 \%$, glutaraldeido $2 \%$, sacarose $3 \%$, cloreto de cálcio $0,005 \mathrm{M}$ em meio tamponado por cacodilato de sódio $0,1 \mathrm{M}$ ) por $4 \mathrm{~h}$ a temperatura ambiente. $\mathrm{O}$ fixador foi então retirado, o material fixado foi lavado com tampão cacodilato de sódio $0,1 \mathrm{M}$ e posteriormente depositado em lamínulas de vidro recobertas com poli-L-lisina. As amostras foram então pósfixadas com tetróxido de ósmio (1\%) durante 30min, lavadas com água destilada e gradualmente desitratadas em acetona $50,70,90$ e $100 \%$, por 5 minutos em cada concentração. $\mathrm{O}$ material foi submetido ao procedimento de secagem ao ponto crítico de $\mathrm{CO}_{2}$ no equipamento Balzers CPD 030 (Balzers Union $A G$, Liechtenstein) e posteriormente metalizado com vapores de ouro no metalizador Balzers SCD 050 (Balzers Union AG, Liechtenstein). As amostras foram então submetidas a análise no microscópio eletrônico de varredura JEOL JSM-7001F (JEOL Ltd., Tóquio, Japão) a 15,0kV.

\subsection{Extração de DNA genômico total}

O DNA total das amostras de solo foi extraído utilizando-se o kit Power Soil DNA Isolation Kit (MO Bio Laboratories Inc.), de acordo com as instruções do fabricante. A única adaptação feita no protocolo foi a quantidade de solo necessária para a extração, descrita 
como $0,25 \mathrm{~g}$ nas instruções do kit, mas utilizando-se $0,5 \mathrm{~g}$ nesse trabalho, já que tal quantidade mostrou-se mais adequada em extrações anteriores feitas por nosso grupo.

O DNA total das colônias obtidas no cultivo foi extraído pelo método de fervura, no qual as colônias foram retiradas do meio sólido com o auxílio da alça de níquel-cromo e transferidas para tubos tipo eppendorf, contendo $100 \mu \mathrm{L}$ de tampão salina-fosfato (PBS) $1 \mathrm{X}$. As células foram então homogeneizadas, incubadas a $95^{\circ} \mathrm{C}$ por $10 \mathrm{~min}$ e centrifugadas a $6000 \mathrm{~g}$ por $5 \mathrm{~min}$. $\mathrm{O}$ sobrenadante foi transferido para tubos novos e armazenado a $-20^{\circ} \mathrm{C}$, para a realização posterior de ensaios de PCR.

A qualidade e quantidade de DNA resultante de ambos os procedimentos de extração foram avaliados por eletroforese em gel de agarose $1 \%$ corado com brometo de etídio (10 $\mathrm{mg} / \mathrm{mL}$ ). O DNA extraído diretamente das amostras de solo, por meio do Power Soil DNA Isolation Kit (MO Bio Laboratories Inc.), foi ainda quantificado no espectofotômetro Nanophotometer da IMPLEM. Tal equipamento foi gentilmente cedido pelo grupo da Prof. Maria Sueli Felipe, do Laboratório de Biologia Molecular da UnB.

\subsection{Reações de PCR}

\subsubsection{Com DNA total extraído dos solos}

Foram realizadas reações de PCR com dois pares de iniciadores específicos para o domínio Archaea: 21f/958r (DeLong, 1992), cujo o alvo é o gene do RNA ribossomal 16S e Arch amoaF/Arch amoaR para o gene da subunidade A da enzima amônia monoxigenase (amoA) (Francis et al., 2005). As sequências dos iniciadores empregados e o tamanho do fragmento esperado para cada par de iniciadores são apresentados na Tabela 1.

Tabela 1. Iniciadores específicos para os genes do rRNA $16 \mathrm{~S}$ e amoA de Archaea utilizados nas reações de PCR.

\begin{tabular}{clc}
\hline Iniciador & \multicolumn{1}{c}{ Sequência } & Fragmento esperado \\
\hline $21 \mathrm{f}$ & 5' TTC CGG TTG ATC CYG CCG GA 3' & \multirow{2}{*}{$937 \mathrm{pb}$} \\
958r & 5' YCC GGC GTT GAM TCC AAT T 3' & \\
Arch amoAf & 5'-STA ATG GTC TGG CTT AGA CG-3' & \multirow{2}{*}{$635 \mathrm{pb}$} \\
Arch amoAr & 5'-GCG GCC ATC CAT CTG TAT GT-3' & \\
\hline
\end{tabular}

Y: pirimidina, M: adenina ou citosina, $\mathrm{S}$ : guanina ou citosina

As reações de PCR foram realizadas em sistemas com volume final de $50 \mu \mathrm{L}$, contendo $5 \mu \mathrm{L}$ de DNA total, em diferentes concentrações, que variaram de 1 a $100 \mathrm{ng}$. As 
concentrações finais para os demais reagentes para as reações de PCR com ambos os pares de iniciadores foram: $1 \mathrm{X}$ de tampão de reação (Invitrogen), $1,5 \mu \mathrm{M}$ de $\mathrm{MgCl}_{2}, 400 \mathrm{ng} / \mu \mathrm{L}$ de soroalbumina bovina (BSA), 0,5 $\mu \mathrm{M}$ de cada iniciador, $200 \mu \mathrm{M}$ de dNTPs e 1,25 $\mathrm{U}$ de TaqDNA Polimerase (Invitrogen). Os ensaios de PCR foram realizados em um termociclador Bio Rad PTC-100 ${ }^{\circledR}$ (Peltier Thermal Cycler) nas condições de ciclagem descritas na Tabela 2.

Tabela 2. Condições dos ensaios de PCR com os iniciadores específicos para os genes do rRNA $16 \mathrm{~S}$ e amoA de Archaea.

\begin{tabular}{lcc}
\hline & $\mathbf{2 1 f} / \mathbf{9 5 8}$ & Arch amoAf/ Arch amoAr \\
\hline 1 & Desnaturação a $94^{\circ} \mathrm{C}$ por $1 \mathrm{~min}$ & Desnaturação a $95^{\circ} \mathrm{C}$ por 5 min \\
2 & Desnaturação a $94^{\circ} \mathrm{C}$ por $1 \mathrm{~min}$ & Desnaturação a $95^{\circ} \mathrm{C}$ por 45 seg \\
3 & Anelamento a $55^{\circ} \mathrm{C}$ por $1 \mathrm{~min}$ & Anelamento a $53{ }^{\circ} \mathrm{C}$ por 1 min \\
4 & Extensão a $72{ }^{\circ} \mathrm{C}$ por 1 min e 30 seg & Extensão a $72{ }^{\circ} \mathrm{C}$ por 1 min \\
5 & Repetição dos passos 2 a $4-29$ vezes & Repetição dos passos 2 a $4-29$ vezes \\
6 & Extensão final a $72{ }^{\circ} \mathrm{C}$ por 5 min & Extensão final a $72{ }^{\circ} \mathrm{C}$ por 10 min \\
7 & Manutenção a $4{ }^{\circ} \mathrm{C}$ & Manutenção a $4{ }^{\circ} \mathrm{C}$ \\
\hline
\end{tabular}

\subsubsection{Com DNA extraído das colônias}

Foram realizados experimentos de PCR utilizando-se o par de iniciadores 21f/958r específicos para o gene rRNA 16s de Archaea (Tabela 1), nas mesmas condições já citadas acima (Tabela 2) e também o par de iniciadores 27f/1492r (Lane, 1991) específicos para o gene do rRNA $16 \mathrm{~S}$ do domínio Bacteria, cujas sequências estão na Tabela 3 e as condições de PCR descritas abaixo:

1) Desnaturação a $94^{\circ} \mathrm{C}$ por $5 \mathrm{~min}$

2) Desnaturação a $94^{\circ} \mathrm{C}$ por $1 \mathrm{~min}$

3) Anelamento a $55^{\circ} \mathrm{C}$ por $1 \mathrm{~min}$

4) Extensão a $72^{\circ} \mathrm{C}$ por $2 \mathrm{~min}$

5) Repetição dos passos 2 a 4 - 29 vezes

6) Extensão final a $72^{\circ} \mathrm{C}$ por $10 \mathrm{~min}$

7) Manutenção a $4^{\circ} \mathrm{C}$ 
Tabela 3. Iniciadores específicos para o gene do rRNA 16S de Bacteria empregados nas reações de PCR com o DNA extraído das colônias cultivadas.

\begin{tabular}{ccc}
\hline Iniciadores & \multicolumn{1}{c}{ Sequência } & $\begin{array}{c}\text { Fragmento } \\
\text { esperado }\end{array}$ \\
\hline 27f & 5' AGA GTT TGA TCC TGG CTC AG 3' & $1465 \mathrm{pb}$ \\
$1492 \mathrm{r}$ & 5' GGT TAC CTT GTT ACG ACT T 3' & \\
\hline
\end{tabular}

As reações de PCR com o DNA extraído das colônias cultivadas foram feitas em sistemas com volume final de $30 \mu \mathrm{L}$, empregando as mesmas concentrações finais dos reagentes já listadas acima. As concentrações de DNA empregadas foram de aproximadamente 1,3 e $5 \mathrm{ng} / \mu \mathrm{L}$, em um volume final de $5 \mu \mathrm{L}$ por reação.

Em todos os experimentos de PCR realizados, um controle negativo foi utilizado, adicionando-se água à reação em substituição ao DNA. Os produtos das reações de PCR foram analisados por eletroforese em gel de agarose $1 \%$ corado com brometo de etídio $(10 \mathrm{mg} / \mathrm{ml})$ e seu tamanho foi estimado com o auxílio do marcador de massa molecular $1 \mathrm{~kb}$ Plus DNA Ladder (Invitrogen).

\subsection{Purificação e ligação dos fragmentos amplificados no vetor pGEM-T easy}

Todos os produtos resultantes das reações de PCR foram purificados com kit GeneJET PCR Purification (Thermo Scientific), conforme as instruções do fabricante. Os fragmentos amplificados a partir do DNA extraído das colônias foram submetidos diretamente ao sequenciamento após a purificação, enquanto os fragmentos amplificados a partir do DNA total dos solos foram purificados e ligados ao vetor pGEM-T easy ${ }^{\circledR}$ (Promega), na proporção de 3:1 de inserto:vetor, de acordo com as instruções do fabricante. Os sistemas de ligação foram mantidos por $1 \mathrm{~h}$ em temperatura ambiente e em seguida foram armazenados a $4^{\circ} \mathrm{C}$ por uma noite.

\subsection{Preparação de células competentes Escherichia coli DH5a}

As células de E. coli DH5a foram inoculadas em $10 \mathrm{~mL}$ de meio Luria Bertani (LB) e incubadas a $37^{\circ} \mathrm{C}$ sem agitação por uma noite. Após este período, $300 \mu \mathrm{L}$ da cultura foram inoculados em $30 \mathrm{~mL}$ de meio $\mathrm{LB}$ sob agitação de $200 \mathrm{rpm}$ a $37^{\circ} \mathrm{C}$ até que a cultura atingisse uma densidade óptica $\left(\mathrm{OD}_{600}\right)$ entre 0,2 e 0,3. Neste momento, as células foram centrifugadas a $4000 \mathrm{~g}$, por $10 \min$ a $4^{\circ} \mathrm{C}$. O sobrenadante foi então descartado e o sedimento de células foi ressuspendido em $15 \mathrm{~mL}$ de solução de cloreto de cálcio $100 \mathrm{mM}$ fria. As células 
ressuspendidas nessa solução foram mantidas em gelo por 20 a 30min e, em seguida, centrifugadas a $2000 \mathrm{~g}$ por $10 \mathrm{~min}$, a $4^{\circ} \mathrm{C}$. O sobrenadante foi mais uma vez descartado e o pellet de células foi ressuspendido em $1 \mathrm{~mL}$ da solução de cloreto de cálcio $100 \mathrm{mM}$ fria e estocado em gelo por 30min.

\subsection{Transformação por choque térmico}

Alíquotas de $100 \mu \mathrm{L}$ das células DH5a competentes foram distribuídas em tubos de hemólise e $5 \mu \mathrm{L}$ do sistema de ligação foram misturados às células. Os tubos contendo as células e os sistemas de ligação foram então incubados por mais 30min em gelo e em seguida foram rapidamente incubados em banho a $37^{\circ} \mathrm{C}$ por $5 \mathrm{~min}$. Ao final desse tempo, $1 \mathrm{~mL}$ de meio LB foi adicionado a cada tubo e o sistema incubado em estufa a $37^{\circ} \mathrm{C}$ por $1 \mathrm{~h}$.

Após esse período, diferentes quantidades do sistema de transformação (50 a $150 \mu \mathrm{L}$ ) foram inoculadas em placas de meio LB sólido (1,5\% de ágar) suplementado com ampicilina $(150 \mu \mathrm{g} / \mathrm{mL}), \mathrm{Xgal}(0,00625 \%)$ e IPTG $(0,5 \mathrm{mM})$. As células foram semeadas com o auxílio de pérolas de vidro estéreis e as placas foram incubadas em estufa a $37^{\circ} \mathrm{C}$ por 16 a $24 \mathrm{~h}$, até a observação de colônias brancas e/ou azuis.

\subsection{Seleção e estoque em glicerol dos clones recombinantes}

As colônias brancas foram retiradas da placa com o auxílio de palitos de madeira estéreis e inoculadas em $5 \mathrm{~mL}$ de meio LB líquido suplementado com ampicilina $(150 \mu \mathrm{g} / \mathrm{mL})$. Os tubos contendo as culturas recém inoculadas foram então incubados em estufa a $37^{\circ} \mathrm{C}$ por uma noite e alíquotas de cada cultura foram misturadas a um mesmo volume de glicerol 70\%, resultando numa concentração final de $35 \%$ de glicerol. As culturas foram então estocadas a $20^{\circ} \mathrm{C}$.

\subsection{Extração de DNA plasmidial por lise alcalina}

Os clones estocados em glicerol foram inoculados em meio LB suplementado com ampicilina $(150 \mu \mathrm{g} / \mathrm{mL})$ e incubados em estufa a $37^{\circ} \mathrm{C}$ por uma noite. A cultura resultante foi centrifugada a $6000 \mathrm{~g}$ por $5 \mathrm{~min}$ e o sobrenadante foi descartado. O pellet foi então ressuspendido em $100 \mu \mathrm{L}$ de solução I $(50 \mathrm{mM}$ de glicose, $25 \mathrm{mM}$ de Tris- $\mathrm{HCl}, 10 \mathrm{mM}$ de EDTA pH 8,0) e incubado por 5 min à temperatura ambiente. Em seguida, foram adicionados 
$200 \mu \mathrm{L}$ de solução II preparada no momento do uso (1\% SDS, $0,2 \mathrm{M}$ de $\mathrm{NaOH}$ ) e a mistura foi suavemente homogeneizada. Os tubos foram incubados no gelo por $5 \mathrm{~min}$. Por fim, foram adicionados $150 \mu \mathrm{L}$ de solução III (3M de acetato de potássio, 2M de ácido acético glacial), mais uma homogeneização foi realizada e os tubos foram novamente incubados por $5 \mathrm{~min}$ no gelo. Os tubos foram então centrifugados a $12000 \mathrm{~g}$ por $5 \mathrm{~min}$, a $4^{\circ} \mathrm{C}$ e os sobrenadantes foram transferidos para novos tubos, aos quais foram adicionados $5 \mu \mathrm{L}$ de RNAse A $(10 \mathrm{mg} / \mathrm{mL})$. As amostras foram então incubadas a $37^{\circ} \mathrm{C}$ de $1 \mathrm{a} 2 \mathrm{~h}$.

Após esse período, um volume igual de clorofane (fenol, clorofórmio e álcool isoamílico, na proporção 25:24:1) foi adicionado às amostras, que foram vigorosamente homogeneizadas e centrifugadas a $7000 \mathrm{~g}$ por $3 \mathrm{~min}$, a $4^{\circ} \mathrm{C}$. A fase aquosa do sobrenadante foi então transferida para um novo tubo tipo eppendorf e um volume igual de clorofil (clorofórmio e álcool iso-amílico, na proporção 24:1) foi adicionado. Após serem mais uma vez bem misturadas, as amostras foram centrifugadas novamente a $7000 \mathrm{~g}$ por $3 \mathrm{~min}$, a $4^{\circ} \mathrm{C}$. Os sobrenadantes resultantes foram transferidos para novos tubos e 3 volumes de etanol 100\% gelado foram adicionados. Os tubos foram estocados a $-20^{\circ} \mathrm{C}$ e após $24 \mathrm{~h}$ foram centrifugados a $12000 \mathrm{~g}$ por $5 \mathrm{~min}$ a $4^{\circ} \mathrm{C}$, o sobrenadante descartado e $300 \mu \mathrm{L}$ de etanol $70 \%$ foram adicionados às amostras. Os tubos foram então mais uma vez centrifugados nas mesmas condições anteriores e o tubo foi deixado invertido a temperatura ambiente para a secagem do pellet.

Após a completa secagem dos pellets, estes foram ressuspendidos em $50 \mu \mathrm{L}$ de $\mathrm{H}_{2} \mathrm{O}$ milli-Q e estocados a $-20^{\circ} \mathrm{C}$. A qualidade e concentração dos plasmídeos obtidos foi analisada em eletroforese em gel de agarose 1\%, com auxílio do marcador de massa molecular High Mass da Invitrogen.

\subsection{Sequenciamento de DNA e análises de bioinformática}

Alguns plasmídeos contendo os fragmentos de interesse foram sequenciados no Laboratório de Biologia Molecular da Universidade de Brasília, no sequenciador automático ABI3730 da Applied Biosystems, enquanto os demais DNAs plasmidiais foram sequenciados pelos serviços da empresa Macrogen. Os iniciadores 21f ou Arch amoAf foram utilizados no sequenciamento, de acordo com o iniciador utilizado na reação de PCR.

As sequências de DNA obtidas foram analisadas quanto à qualidade pelo algoritmo PHRED (Ewing et al., 1998), através da ferramenta Electropherogram quality analysis disponível na página da EMBRAPA, no endereço eletrônico: 
http://asparagin.cenargen.embrapa.br/phph/. Foram selecionadas as sequências com mais de 250 nucleotídeos e que apresentaram valor de PHRED superior a 20. Sequências com valores inferiores a 20 foram descartadas.

As sequências relativas ao gene de rRNA $16 \mathrm{~S}$ selecionadas foram então submetidas a análises comparativas no banco de dados taxonômico do Greengenes (DeSantis et al., 2006), através do programa Mothur (Schloss et al., 2009). As sequências correspondentes aos genes de rRNA16S e de amoA foram submetidas a alinhamentos múltiplos, utilizando-se o programa ClustalX (Larkin et al., 2007) e o resultado do alinhamento foi então editado manualmente com o auxílio do programa BioEdit (http://www.mbio.ncsu.edu/bioedit/bioedit.html). Regiões de sequências de difícil edição e sequências muito curtas (menores que 400 pares de bases) foram eliminadas.

As sequências do gene de rRNA $16 \mathrm{~S}$ foram utilizadas para análises de alfa e betadiversidade. A riqueza de unidades taxonômicas operacionais (OTUs) foi estimada pelo programa Mothur, que também foi utilizado para a obtenção dos coeficientes de riqueza e diversidade: Chao1, ACE, Simpson e Shannon. O Mothur foi utilizado ainda para a obtenção das curvas de rarefação, empregando-se como limite de corte $80 \%$ para o nível taxonômico de filo, 90\% para classe, 95\% para gênero e 97\% para espécie. Para se avaliar as OTUs compartilhadas entre as amostras, diagramas de Venn foram construídos por meio de comando disponíveis no programa Mothur. Para as análises de beta-diversidade foram realizados os testes $\int$-Libshuff (Schloss et al., 2004) e Weighted Unifrac (Luzopone et al., 2007), este último para a obtenção de um gráfico de Análise de Coordenadas Principais (PCoA). O J-Libshuff foi realizado por meio do programa Mothur, com o objetivo de se identificar se havia diferenças significativas entre as comunidades microbianas das diferentes amostras. As coordenadas para o gráfico PCoA foram geradas pelo programa Mothur utilizando-se o teste Weighted Unifrac e o gráfico foi construído com o auxílio do programa PAST3 (Hammer et al., 2001).

As sequências do gene amoA foram analisadas com ferramentas disponíveis no programa Mothur para a obtenção do número de OTUs observadas considerando-se um coeficiente de dissimilaridade de 3\%, assim como a cobertura da amostragem.

As sequências do gene de rRNA 16S de Archaea e Bacteria obtidas do cultivo também foram analisadas quanto à qualidade pelo algoritmo PHRED (Ewing et al., 1998) e somente aquelas que apresentaram um valor de qualidade superior a 20 em mais de 250 bases foram consideradas. As sequências obtidas para os dois domínios foram então classificadas 
utilizando-se novamente o banco de dados Greengenes (DeSantis et al., 2006), por meio do programa Mothur.

Diferentes árvores filogenéticas com sequências do gene rRNA 16S (tanto as obtidas a partir do cultivo quanto as obtidas independentemente de cultivo) e do gene amoA foram construídas pelo programa MEGA5 (Tamura et al., 2011), pelo método de Neighbor-joining (Saitou \& Nei, 1987), com o modelo de Jukes-Cantor (Jukes \& Cantor, 1969) e teste de bootstrap de 1000 repetições (Felsenstein, 1985). Sequências representativas a nível de espécie (3\%), obtidas por ferramentas do programa Mothur, foram comparadas a sequências disponíveis no banco de dados do NCBI (US National Center of Biotechnology Informantion) por meio da ferramenta BLAST (Altschul et al., 1990) e aquelas que apresentaram os mais altos valores de similaridade foram incluídas nas árvores. 


\section{Resultados e Discussão}

Tendo em vista as duas abordagens adotadas neste trabalho, os resultados serão apresentados e discutidos em dois itens distintos, denominados 4.1. Filogenia molecular de Archaea em solos de Cerrado sensu stricto submetidos ou não a queimadas periódicas e 4.2. Obtenção de culturas de Archaea em meios artificiais.

\subsection{Filogenia molecular de Archaea em solos de Cerrado sensu stricto submetidos ou não a queimadas periódicas}

\subsubsection{Coleta dos solos e análises dos seus parâmetros físico-químicos}

Os solos utilizados para as análises de filogenia molecular foram coletados no início do mês de setembro de 2013, período de transição entre a estação seca e chuvosa. A Reserva Ecológica do IBGE disponibiliza em sua página na Internet (www.recor.org.br) dados referentes a precipitação diária na reserva. Os índices pluviométricos totais mensais registrados na RECOR para o ano de 2013 estão apresentados na Figura 3. É importante ressaltar que apesar de no mês de setembro ter sido registrada uma precipitação total de 48,6 $\mathrm{mm}$, as chuvas só ocorreram a partir da segunda quinzena deste mês. Desta forma, a coleta do solo (realizada no dia 02 de setembro) ocorreu em um período de déficit hídrico, já que as últimas precipitações antes da data da coleta foram registradas em junho e só voltaram a ocorrer mais de 10 dias depois.

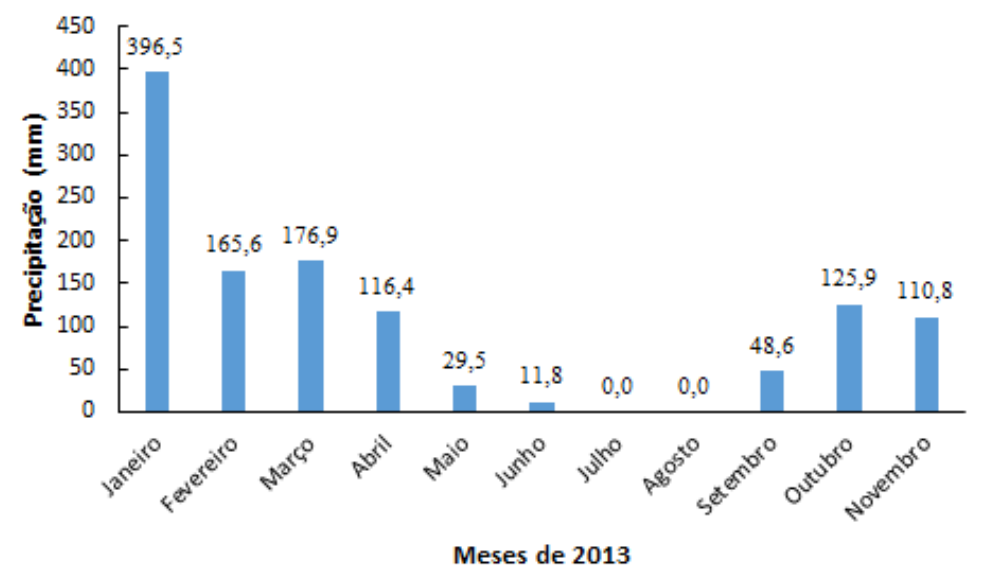

Figura 3. Precipitação mensal registrada na Reserva Ecológica do IBGE, ao longo do ano de 2013. Dados obtidos na página da Reserva (www.recor.org.br/cid360/download/17-dados-meteorológicos.html). 
Os parâmetros físico-químicos dos solos coletados em ambas as áreas (Controle e Queimada) foram analisados pela empresa SOLOQUÍMICA Análises de Solo LTDA e a Tabela 4 apresenta os valores obtidos nessas análises. Devido a limitações, as análises dos parâmetros físico-químicos só puderam ser realizadas em um ponto de cada uma das áreas. Tal condição não é a ideal, já que seriam necessárias medições dos parâmetros no solo de cada uma das réplicas para que pudessem ser correlacionados com os dados relativos às comunidades microbianas. Além disso, com apenas uma medição por área não é possível afirmar que os valores refletem as condições físico-químicas do solo em cada uma das áreas (submetida à queimada bienal e protegida do fogo) como um todo, podendo estar relacionados a algum fator ambiental específico do ponto da coleta. No entanto, os valores obtidos serão apresentados a título de referência e, quando possível e necessário, correlacionados com dados de outros estudos realizados nas mesmas áreas das coletas.

Tabela 4. Valores dos parâmetros físico-químicos dos solos de Cerrado sensu stricto coletados nas áreas Controle e Queimada.

\begin{tabular}{lcc}
\hline Parâmetros Analisados & Cerrado Controle & Cerrado Queimado \\
\hline Argila $(\mathrm{g} / \mathrm{kg})$ & 325 & 350 \\
Areia $(\mathrm{g} / \mathrm{kg})$ & 425 & 400 \\
Silte $(\mathrm{g} / \mathrm{kg})$ & 250 & 250 \\
$\mathrm{pH}$ & 5,20 & 5,10 \\
Fósforo $(\mathrm{ppm})$ & 0,60 & 0,70 \\
Cálcio $\left(\mathrm{cmol}_{\mathrm{c}} / \mathrm{dm}^{3}\right)$ & 0,30 & 0,50 \\
Magnésio $\left(\mathrm{cmol}_{\mathrm{c}} / \mathrm{dm}^{3}\right)$ & 0,10 & 0,30 \\
Potássio $\left(\mathrm{cmol}_{\mathrm{c}} / \mathrm{dm}^{3}\right)$ & 0,09 & 0,11 \\
Sódio $\left(\mathrm{cmol}_{\mathrm{c}} / \mathrm{dm}^{3}\right)$ & 0,01 & 0,02 \\
Alumínio $\left(\mathrm{cmol} / \mathrm{dm}^{3}\right)$ & 1,60 & 1,40 \\
Carbono Orgânico $(\mathrm{g} / \mathrm{kg})$ & 34,8 & 36,4 \\
Nitrogênio total $(\mathrm{g} / \mathrm{kg})$ & 0,70 & 0,53 \\
Nitrogênio nitrato & 0,20 & 0,25 \\
Nitrogênio nitrito & 0,15 & 0,10 \\
Nitrogênio amoniacal & 0,05 & 0,05 \\
Matéria Orgânica $(\mathrm{g} / \mathrm{kg})$ & 59,9 & 62,6 \\
Boro $(\mathrm{ppm})$ & 0,36 & 0,50 \\
Cobre $(\mathrm{ppm})$ & 0,26 & 0,13 \\
Ferro $(\mathrm{ppm})$ & 66,6 & 72,5 \\
Manganês $(\mathrm{ppm})$ & 2,78 & 6,65 \\
Zinco (ppm) & 0,19 & 0,07 \\
Enxofre & 9,7 & 10,5 \\
\hline
\end{tabular}

Vale ressaltar que embora efeitos imediatos das queimadas nas propriedades e composição dos solos tenham sido relatados na literatura, principalmente relacionados ao aumento temporário de $\mathrm{pH}$ gerado pela deposição de cinzas resultantes da vegetação 
queimada e a mobilização de nutrientes estocados na biomassa viva e serapilheira para o solo (Pivello \& Coutinho, 1992; Miranda et al., 2004; Pivello et al., 2010), pouco se sabe sobre os efeitos de longo prazo das queimadas frequentes nos solos de Cerrado. No entanto, já foi constatado que o aumento da disponibilidade de nutrientes no solo após as queimadas está restrito às camadas mais superficiais e é de curta duração, provavelmente devido ao rápido restabelecimento da vegetação rasteira, que assegura a reincorporação de componentes como o K, Ca e Mg, e a lixiviação dos nutrientes com as primeiras chuvas (Miranda et al., 2004).

Em um trabalho realizado por Moreira (2000) que visava avaliar os efeitos do fogo a longo prazo em áreas de Cerrado da mesma reserva ecológica onde foram coletadas as amostras para este trabalho (RECOR-IBGE), não foram constatadas diferenças significativas nos parâmetros físico-químicos avaliados nos solos de áreas frequentemente queimadas e áreas protegidas do fogo.

\subsubsection{Extração de DNA genômico total}

Os solos de ambas as áreas foram coletados em triplicata, como descrito anteriormente. As réplicas coletadas na área Controle (área protegida do fogo há mais de 15 anos) foram denominadas $\mathrm{Ca}, \mathrm{Cb}$ e $\mathrm{Cc}$, enquanto as réplicas coletadas na região de queima bienal (denominada de "Queimada" daqui para frente) foram denominadas Qa, Qb e Qc.

O perfil eletroforético obtido no gel de agarose $1 \%$ corado com brometo de etídio revelou que a extração de DNA total das amostras de solo de ambas as áreas foi eficiente (Figura 4). Fragmentos de DNA de alta massa molecular e pequeno grau de fragmentação puderam ser observados em todas as amostras.

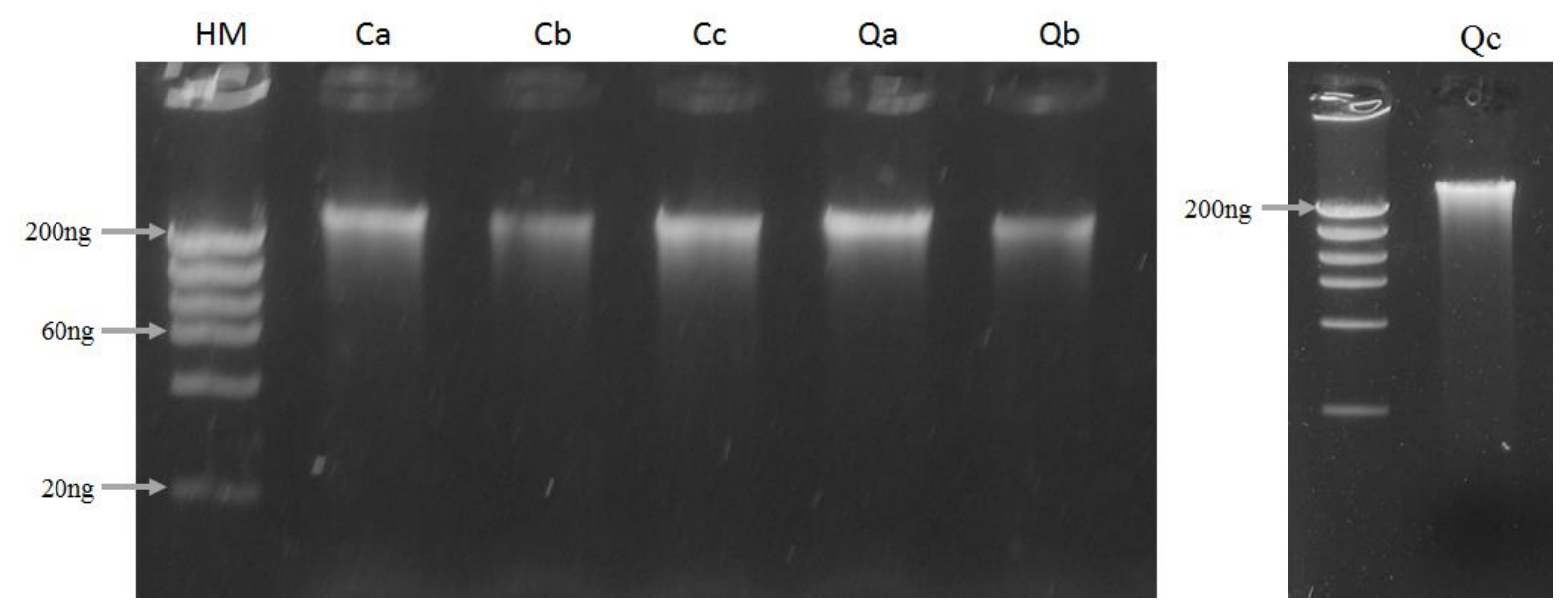

Figura 4. Perfil eletroforético, em gel de agarose $1 \%$ corado com brometo de etídio, do DNA total extraído do solo das áreas Controle ( $\mathrm{Ca}, \mathrm{Cb}, \mathrm{Cc})$ e Queimada (Qa, Qb e Qc), em triplicata. HM: Marcador de massa molecular High DNA Mass Ladder (Invitrogen). 
As concentrações dos DNAs extraídos das diferentes amostras de solo também foram aferidas em espectrofotômetro Nanophotometer (IMPLEM) e os resultados podem ser vistos na Tabela 5.

Tabela 5. Concentrações dos DNAs extraídos das diferentes amostras de solo, aferidas pelo espectrofotômetro Nanophotometer da IMPLEM.

\begin{tabular}{ccc}
\hline Amostra & Concentração de DNA $(\mathbf{n g} / \mathbf{\mu L})$ & $\mathbf{A 2 6 0 / 2 8 0 *}$ \\
\hline $\mathrm{Ca}$ & 29,5 & 1,903 \\
$\mathrm{Cb}$ & 14,5 & 1,933 \\
$\mathrm{Cc}$ & 24,5 & 1,885 \\
$\mathrm{Qa}$ & 25,5 & 1,962 \\
$\mathrm{Qb}$ & 11,5 & 1,769 \\
$\mathrm{Qc}$ & 25,5 & 1,889 \\
\hline
\end{tabular}

* Razão entre ácidos nucleicos e proteínas obtidos na extração

Valores ideais variam entre 1,8 e 2,0 .

\subsubsection{Amplificação de fragmentos dos genes do rRNA $16 \mathrm{~S}$ e da subunidade A da amônia monoxigenase (amoA) de Archaea por PCR}

DeLong (1992) e Fuhrman (1993), em dois trabalhos independentes, detectaram pela primeira vez a ocorrência de archaeas em ambientes marinhos costeiros e também em profundidades entre 100 e 500 metros, de origem planctônica, não associados a condições anaeróbicas ou temperaturas extremas. Em seu trabalho, DeLong propôs e utilizou os pares de iniciadores 21f/958r para a detecção de membros do domínio Archaea em amostras de bacterioplâncton de diversos ambientes costeiros, os quais se mostraram bastante específicos para o gene do rRNA 16S de archaeas. Desde então, esse par de iniciadores vem sendo utilizado para a detecção de archaeas nos mais diversos ambientes (Bano et al., 2004; Etto et al., 2012; Hansel et al., 2008; Simister et al., 2012). Trabalhos anteriores de nosso grupo de pesquisa também empregaram esse par de iniciadores e demonstraram sua eficiência na descrição de membros do domínio Archaea em solos (Catão et al., 2013) e sedimentos lacustres do cerrado (Rodrigues et al., 2014). Desta forma, esse par de iniciadores - 21f e 958r - foi escolhido neste trabalho para a descrição da comunidade de archaeas em solos de Cerrado sensu stricto submetidos ou não a queimadas bienais.

Para a realização dos experimentos de PCR, os DNAs genômicos totais extraídos dos solos foram diluídos para diferentes concentrações e várias delas foram testadas nas reações. Como pode ser visto na Figura 5, fragmentos com o tamanho esperado para os iniciadores 21f/958r empregados (aproximadamente 940pb) foram obtidos a partir de diferentes concentrações de DNA total. Os fragmentos amplificados a partir de uma mesma amostra, ou 
seja aqueles resultantes de reações com diferentes concentrações de um mesmo DNA, foram então reunidos e purificados conjuntamente, visando assim a obtenção de uma maior concentração final dos produtos de PCR.

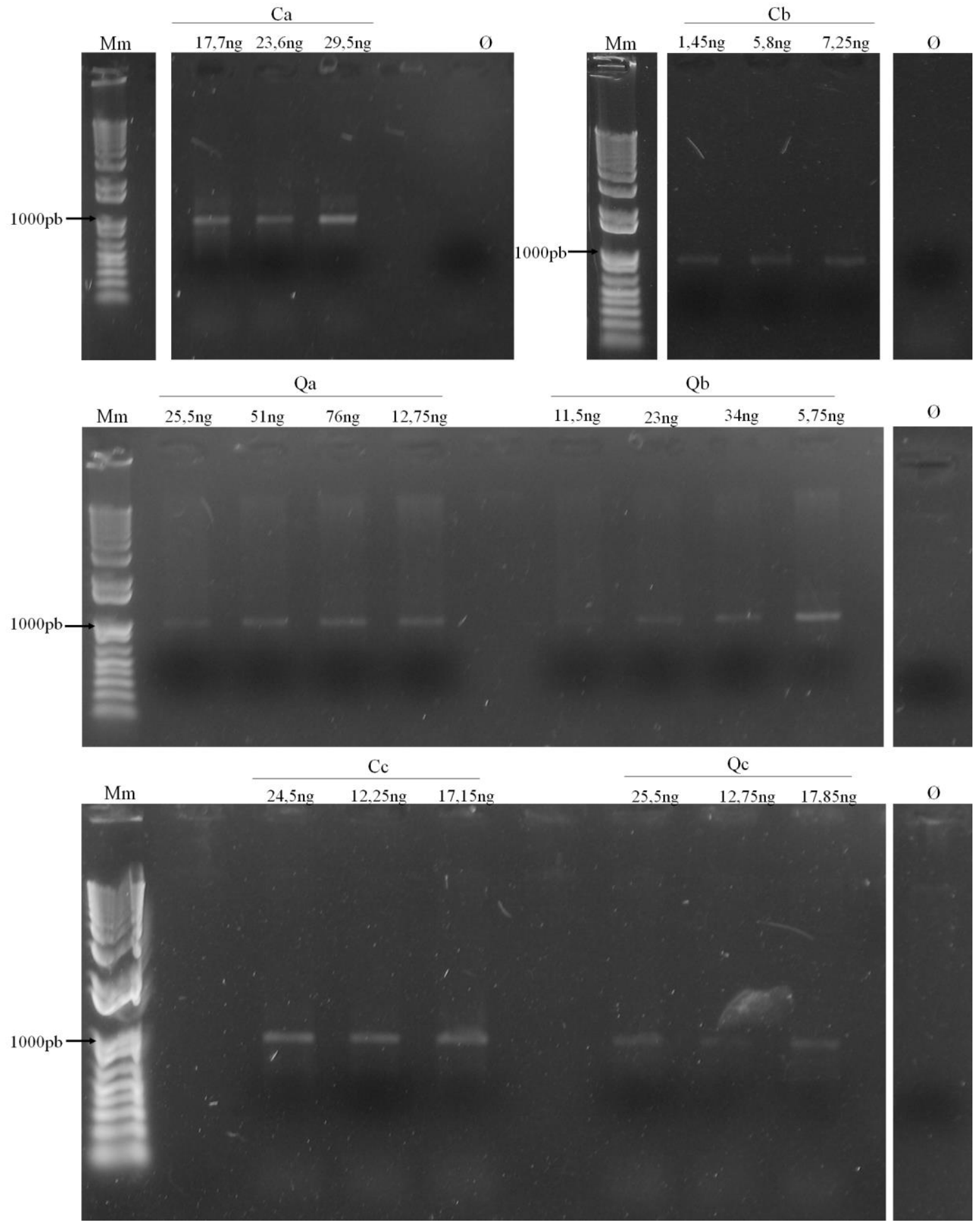

Figura 5. Géis de agarose $1 \%$ corados com brometo de etídio, contendo os fragmentos do gene rRNA $16 \mathrm{~S}$ amplificados por PCR, utilizando-se os iniciadores 21f/958r. Ø: controles negativos das PCRs, onde não foi adicionado DNA; $\mathrm{Ca}, \mathrm{Cb}$ e $\mathrm{Cc}$ : réplicas da área Controle; $\mathrm{Qa}, \mathrm{Qb}$ e $\mathrm{Qc}$ : réplicas da área Queimada; $\mathrm{Mm}$ : marcador de massa molecular $1 k b$ Plus DNA Ladder (Invitrogen). 
Para a detecção do gene que codifica a subunidade A da enzima amônia monoxigenase de Archaea, cuja presença sugeriria o potencial para a oxidação de amônia por esses organismos, foi utilizado o par de iniciadores Arch amoAf/ Arch amoAr (Francis et al., 2005). Tais iniciadores são amplamente utilizados em estudos da oxidação de amônia por archaeas em diferentes ecossistemas marinhos e terrestres (Zhang et al., 2008; Taylor et al., 2012; Li et al., 2012). O fragmento de DNA amplificado por esses iniciadores apresenta $635 \mathrm{pb}$, o que corresponde essencialmente ao gene completo. Em um estudo realizado anteriormente por nosso grupo, os iniciadores Arch amoAf e Arch amoAr foram capazes de detectar a presença do gene $a m o A$ de archaeas em sedimentos de lagoa de cerrado (Rodigues et al., 2014).

Fragmentos de DNA amplificados a partir desse par de iniciadores foram obtidos em todas as réplicas de ambas as áreas (Controle e Queimada), como pode ser visto na Figura 6. Também foram utilizadas diferentes concentrações de DNA de cada amostra nas reações de PCR e, na maioria delas, foi verificada a ocorrência de fragmentos de DNA com tamanho correspondente ao produto de amplificação esperado. Mais uma vez, os fragmentos amplificados a partir de uma mesma amostra foram então reunidos e purificados, visando a obtenção de uma maior concentração final dos produtos de PCR.

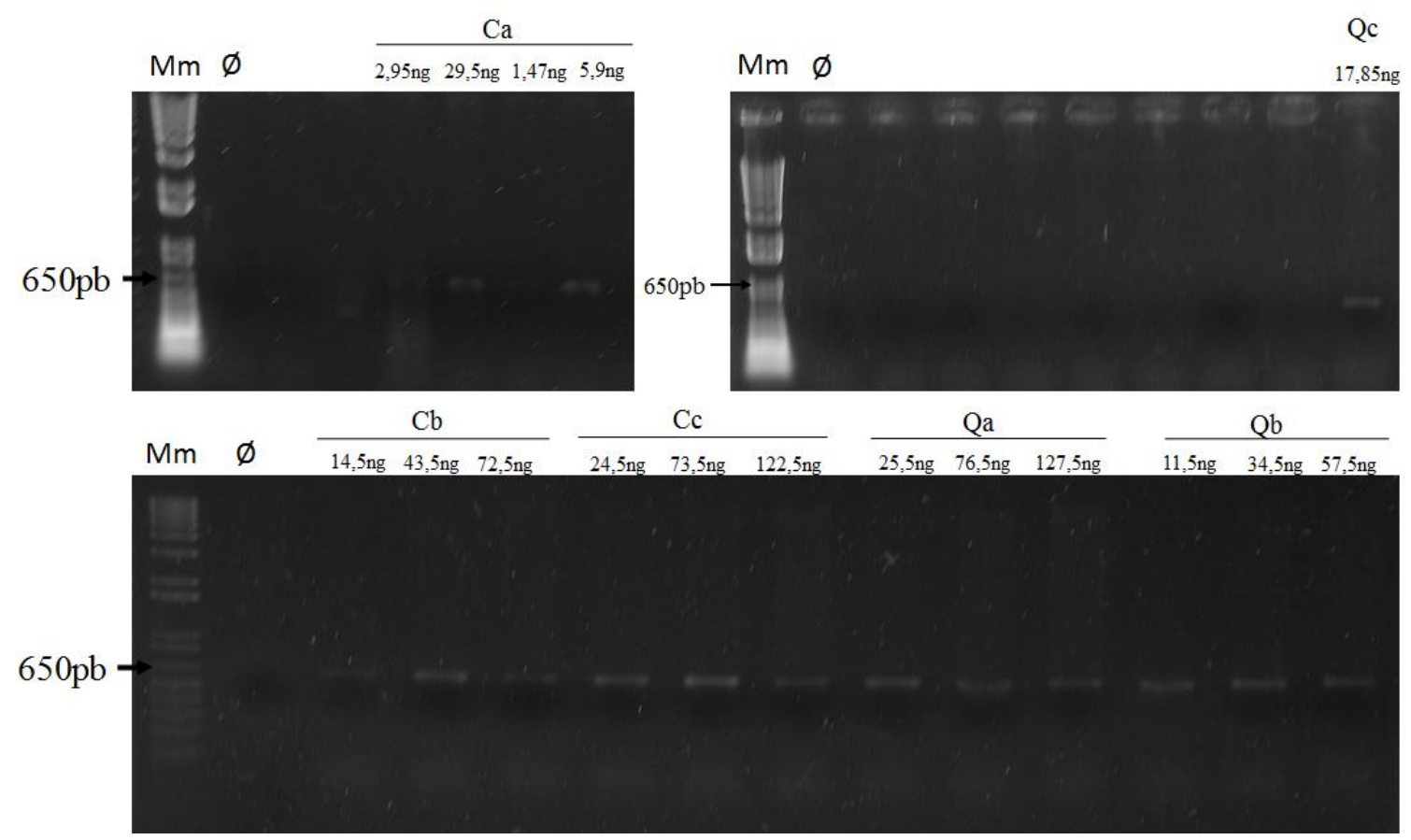

Figura 6. Géis de agarose $1 \%$ corados com brometo de etídio contendo os fragmentos do gene $a m o A$ amplificados por PCR, utilizando-se os iniciadores Arch amoAf/Arch amoAr. $\varnothing$ : controles negativos das PCRs, onde não foi adicionado DNA; $\mathrm{Ca}, \mathrm{Cb}$ e $\mathrm{Cc}$ : réplicas de cerrado Controle; Qa, Qb e Qc: réplicas de cerrado Queimado; Mm: marcador de massa molecular $1 \mathrm{~kb}$ Plus DNA Ladder da Invitrogen. 


\subsubsection{Transformação de Escherichia coli DH5a e seleção de clones recombinantes}

Os fragmentos de DNA amplificados a partir das reações de PCR empregando os iniciadores 21f/958r e Arch amoAf/Arch amoAr foram ligados ao vetor plasmidial pGEM-T Easy $^{\circledR}$ (Promega) e transformados por choque térmico em células de E. coli DH5a. Após a semeadura do sistema de transformação em placas de ágar LB (suplementado com ampicilina, Xgal e IPTG) e sua posterior incubação a $37^{\circ} \mathrm{C}$ por uma noite, colônias recombinantes foram observadas, selecionadas e estocadas em glicerol 35\%. O número de clones obtidos para cada amostra com cada par de iniciadores é apresentado na Tabela 6.

Tabela 6. Número de clones recombinantes obtidos para cada amostra e par de iniciadores.

\begin{tabular}{cc}
\hline Amostra - Iniciadores utilizados & $\mathbf{N}^{0}$ de clones obtidos \\
\hline $\mathrm{Ca}-21 \mathrm{f} / 958 \mathrm{r}$ & 147 \\
$\mathrm{Cb}-21 \mathrm{f} / 958 \mathrm{r}$ & 110 \\
$\mathrm{Cc}-21 \mathrm{f} / 958 \mathrm{r}$ & 102 \\
$\mathrm{Qa}-21 \mathrm{f} / 958 \mathrm{r}$ & 121 \\
$\mathrm{Qb}-21 \mathrm{f} / 958 \mathrm{r}$ & 183 \\
$\mathrm{Qc}-21 \mathrm{f} / 958 \mathrm{r}$ & 100 \\
$\mathrm{Ca}-$ Arch amoAf/Arch amoAr & 80 \\
$\mathrm{Cb}-$ Arch amoAf/Arch amoAr & 80 \\
$\mathrm{Cc}-$ Arch amoAf/Arch amoAr & 67 \\
$\mathrm{Q}$ - Arch amoAf/Arch amoAr & 97 \\
$\mathrm{Qb}-$ Arch amoAf/Arch amoAr & 80 \\
$\mathrm{Qc}-$ Arch amoAf/Arch amoAr & 63 \\
Total de clones obtidos & 1230 \\
\hline
\end{tabular}

\subsubsection{Extração do DNA plasmidial}

O DNA plasmidial dos clones recombinantes selecionados foi extraído pelo método de lise alcalina. A qualidade e concentração dos plasmídeos extraídos foram analisados por meio do perfil eletroforético obtido em gel de agarose $1 \%$ corado com brometo de etídio, como exemplificado na Figura 7. 


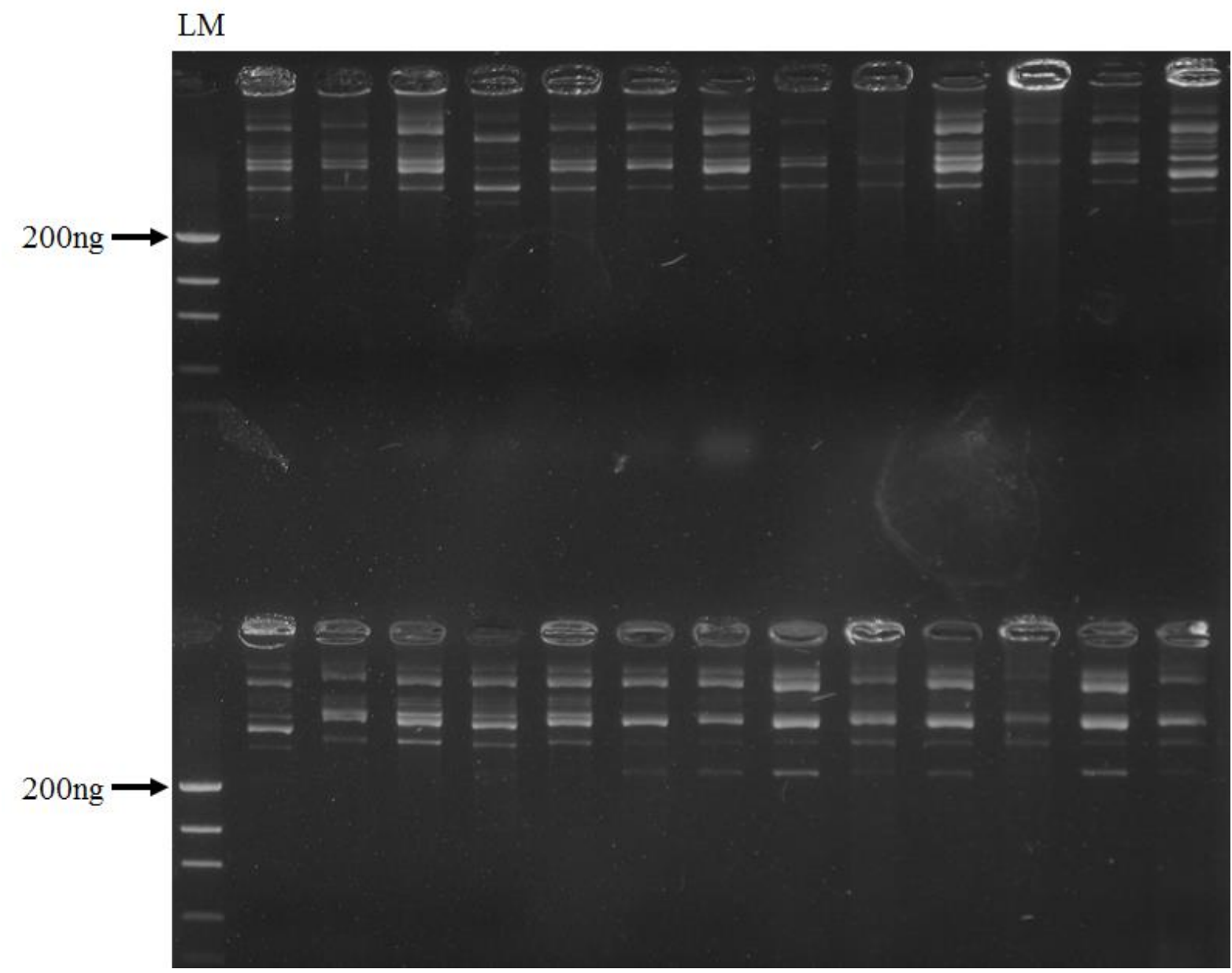

Figura 7. Perfil eletroforético do DNA plasmidial, contendo fragmentos do gene rRNA $16 \mathrm{~S}$ de amostras de Controle e Queimada, de clones recombinantes aleatoriamente selecionados. LM - Marcador de massa molecular Low Mass DNA ladder (Invitrogen).

O número de amostras submetidas ao sequenciamento de DNA não corresponde ao número de clones obtidos para cada amostra. Para as amostras do gene rRNA 16S, inicialmente foram submetidos ao sequenciamento automático 96 clones de cada uma das 6 bibliotecas ( $\mathrm{Ca}, \mathrm{Cb}, \mathrm{Cc}, \mathrm{Qa}, \mathrm{Qb}$ e Qc). Devido a problemas relacionados ao sequenciamento, outros 48 clones de $\mathrm{Ca}$ e 48 clones de $\mathrm{Qb}$ foram posteriormente sequenciados. Para as amostras de amoA, 48 clones de cada biblioteca (amoCa, amoCb, amoCc, amoQa, amoQb, amoQc) foram submetidos ao sequenciamento automático.

\subsubsection{Análises de bioinformática}

Foram sequenciados um total de 672 clones provenientes de 6 bibliotecas do gene rRNA 16S de Archaea (iniciador 21f) e 288 clones de 6 bibliotecas do gene amoA de Archaea (iniciador amoAf). Destas, 512 sequências de rRNA 16S e 256 sequências de amoA 
apresentaram valor PHRED (Ewing et al., 1998) superior a 20 para mais de 250 pares de bases, sendo as demais 160 sequências de rRNA $16 \mathrm{~S}$ e 31 sequências de amoA descartadas. Outras 46 sequências de rRNA $16 \mathrm{~S}$ e 6 sequências de $a m o A$ foram descartadas posteriormente por serem muito curtas, uma vez que apresentavam menos de 400 pares de bases. Dessa forma, um total de 466 sequências de $16 \mathrm{~S}$ e 251 sequências de amoA foram utilizadas nas análises de bioinformática por apresentarem a qualidade adequada. $\mathrm{O}$ número de sequências utilizadas nas análises para cada uma das réplicas pode ser visto na Tabela 7.

Tabela 7. Número de sequências analisadas por bioinformática para cada amostra.

\begin{tabular}{cccc}
\hline Amostra (16S) & $\mathbf{N}^{\mathbf{0}}$ de Sequências & Amostra $(\boldsymbol{a m o A})$ & $\mathbf{N}^{\mathbf{0}}$ de Sequências \\
\hline $\mathrm{Ca}$ & 80 & $\mathrm{amoCa}$ & 44 \\
$\mathrm{Cb}$ & 79 & $\mathrm{amoCb}$ & 45 \\
$\mathrm{Cc}$ & 74 & $\mathrm{amoCc}$ & 39 \\
$\mathrm{Qa}$ & 82 & $\mathrm{amoQa}$ & 47 \\
$\mathrm{Qb}$ & 101 & $\mathrm{amoQb}$ & 46 \\
$\mathrm{Qc}$ & 50 & amoQc & 30 \\
Total & 466 & Total & 251 \\
\hline
\end{tabular}

\subsubsection{Análises de sequências do gene do rRNA 16S}

\subsubsection{Classificação taxonômica pelo banco de dados Greengenes}

O crescente número de sequências do gene rRNA $16 \mathrm{~S}$ depositadas nos bancos de dados, bem como o depósito de sequências de DNA de microrganismos não cultivados sem informações taxonômicas precisas, resultam em uma série de problemas em suas análises, especialmente em relação à nomenclatura e dificuldades quando de seu posicionamento taxonômico (Auguet et al., 2010).

No que se refere à filogenia molecular do domínio Archaea, este problema é ainda maior, devido ao grande número de sequências de DNA de amostras não cultivadas, geradas a partir de trabalhos metagenômicos dos mais diversos ambientes. Além disso, é notório o pequeno número de isolados de archaeas cultivados em meios artificiais, especialmente quando se tratam de archaeas presentes em ambientes não extremos. Outro fator que torna as análises de filogenia molecular de Archaea mais difícil consiste nas várias e frequentes propostas de novos grupos taxonômicos, especialmente em relação aos filos, pois estas criam uma barreira adicional para uma classificação clara desses organismos. Como já abordado na seção 1.2, ao longo dos anos várias propostas para a criação de novos filos de Archaea foram feitas, mas em alguns casos, o isolamento de apenas um genoma ou de poucas amostras de 
DNA levaram a estas proposições. Assim, é necessário obter-se um número maior de isolados cultivados, ou de genomas completos, para que a taxonomia deste grupo seja melhor compreendida.

O banco de dados Greengenes oferece um alinhamento múltiplo de sequências do gene rRNA $16 \mathrm{~S}$ tanto de archaeas quanto de bactérias e leva em consideração a taxonomia proposta por curadores independentes, incluindo o NCBI, Ribossomal Database Project (RDP), entre outros. Por ter essa característica, mesmo sendo encontradas incongruências nas nomenclaturas até mesmo em nível de filo entre os diferentes curadores considerados, este banco de dados visa facilitar a classificação taxonômica dos organismos (DeSantis et al., 2006). Esse banco de dados foi escolhido para as análises das sequências do gene rRNA 16S obtidas nesse trabalho.

As 466 sequências de $16 \mathrm{~S}$ obtidas a partir de todas as réplicas das condições estudadas (Controle e Queimada), apresentaram uma identidade de 100\% com o domínio Archaea. Na Tabela 8 são apresentadas as classificações obtidas para as sequências de cada amostra, sendo apresentado o nível taxonômico até o qual o Greengenes apresentou 100\% de identidade. De acordo com a classificação gerada pelo Greengenes, todas as sequências pertenciam ao filo Crenarchaeota. No entanto, é importante ressaltar que devido às dificuldades de classificação taxonômica já mencionadas, esse banco de dados ainda considera Thaumarchaeota como uma classe do filo Crenarchaeota e não como um filo independente. Neste trabalho, porém, Thaumarchaeota foi considerado um filo, conforme proposto por Brochier-Armanet e colaboradores (2008), e o qual vem sendo assim considerado por vários outros autores (Spang et al., 2010; Pester et al., 2011).

Tabela 8. Classificação taxonômica das sequências do gene rRNA $16 \mathrm{~S}$ gerada pelo Greengenes.

\begin{tabular}{|c|c|c|c|c|c|c|c|}
\hline Amostra & $\begin{array}{l}\text { Número } \\
\text { de seqs }\end{array}$ & $\begin{array}{c}\text { I.1b* }^{*} \\
\text { g_Nitrososphaera** }\end{array}$ & $\%$ & $\begin{array}{c}\text { I.1c* } \\
\text { o_NRP-J*** }\end{array}$ & $\%$ & $\begin{array}{c}\text { MCG***** } \\
\text { o_pGrfC26 }\end{array}$ & $\%$ \\
\hline $\mathbf{C a}$ & 80 & 7 & 8,75 & 73 & 91,25 & 0 & 0,00 \\
\hline $\mathbf{C b}$ & 79 & 32 & 40,50 & 44 & 55,70 & 3 & 3,80 \\
\hline $\mathrm{Cc}$ & 74 & 10 & 13,50 & 64 & 86,50 & 0 & 0,00 \\
\hline Qa & 82 & 32 & 39,00 & 50 & 61,00 & 0 & 0,00 \\
\hline Qb & 101 & 88 & 87,12 & 13 & 12,88 & 0 & 0,00 \\
\hline $\mathbf{Q c}$ & 50 & 17 & 34,00 & 33 & 66,00 & 0 & 0,00 \\
\hline Total & 466 & 186 & 39,91 & 277 & 59,44 & 3 & $\mathbf{0 , 6 4}$ \\
\hline
\end{tabular}

* I.1b e I.1c: grupos do filo Thaumarchaeota

** g_: gênero designado na classificação do Greengenes

*** o_: ordem designada na classificação do Greengenes

**** MCG: Miscellaneous Crenarchaeotic Group 
Dentre as 466 sequências, 186 foram classificadas pelo Greengenes como pertencentes à classe Thaumarchaeota, apresentando $100 \%$ de identidade até o nível taxonômico de gênero, sendo classificadas na ordem Nitrososphaerales, família Nitrososphaeraceae, gênero Candidatus Nitrososphaera. As archaeas deste gênero pertencem a um grupo denominado I.1b, descrito como dominante em diferentes tipos de solo (Bintrim et al., 1997; Auguet et al., 2010; Bates et al., 2011) e que possui alguns representantes cultivados, como Nitrososphaera viennensis e Candidatus Nitrososphaera gargensis. Embora o grupo I.1b tenha sido inicialmente descrito como pertencente ao Grupo I de crenarchaeotas não-extremófilas (DeLong, 1998), as recentes propostas de classificação de tais organismos vêm indicando que os membros do grupo I.1b formam um clado monofilético no filo Thaumarchaeota (Pester et al., 2011).

Em relação às áreas amostradas, observa-se que na réplica b da área Queimada $(\mathrm{Qb}), \mathrm{a}$ proporção de amostras pertencentes ao grupo I.1b é bastante expressiva, correspondendo a $87,12 \%$ de todas as sequências desta amostra. Nas demais réplicas, este grupo foi o segundo, em termos de frequência de detecção.

A grande maioria das demais sequências do gene rRNA 16S (total de 277) obtidas neste trabalho foram classificadas pelo Greengenes como pertencentes à ordem NRP-J. Esta ordem contém os clados pertencentes ao grupo I.1c (Swanson \& Sliwinski, 2013). Esse grupo, inicialmente detectado em solos de floresta da Finlândia (Jurgens et al., 1997), foi posteriormente identificado em diversos outros trabalhos baseados em sequências ambientais de rRNA 16S (Hansel et al., 2008; Lehtorvita et al., 2009; Bates et al., 2011). Assim como o grupo I.1b, o grupo I.1c foi inicialmente descrito como pertencente ao Grupo I de crenarchaeotas não-extremófilas e, apesar de não possuir representantes cultivados até o momento, vem sendo posicionado no filo Thaumarchaeota por formar um agrupamento monofilético com outros organismos incluídos neste filo (Pester et al., 2011; BrochierArmanet et al., 2012). Novamente, a amostra Qb mostrou-se com perfil distinto das demais, uma vez que foram detectadas poucas sequências do grupo I.1c, enquanto nas demais réplicas, este foi o grupo mais frequentemente detectado.

As 3 sequências restantes foram classificadas como pertencentes à ordem pGrfC26 do grupo Miscellaneous Crenarchaeotal Group (MCG), sendo todas oriundas da réplica b da área Controle (amostra $\mathrm{Cb}$ ). Até o momento, este grupo é representado apenas por sequências de rRNA 16S encontradas em diferentes ambientes terrestres e marinhos e forma um clado distinto de Crenarchaeota e Thaumarchaeota, sendo de difícil posicionamento em árvores filogenéticas (Kubo et al., 2012). 
Um aspecto digno de nota refere-se à aparente homogeneidade taxonômica das sequências encontradas entre o solo da área queimada bienalmente e o solo da área protegida do fogo há muitos anos. Com exceção das três sequências da réplica $\mathrm{Cb}$ classificadas como pertencentes ao Miscellaneous Crenarchaeotic Group, todas as demais sequências de ambas as condições estão distribuídas entre os grupos I.1b e I.1c do filo Thaumarchaeota. Ao que parece, o regime de queima bienal em áreas de Cerrado sensu stricto não leva a diferenças na composição da comunidade de archaeas do solo.

Vale ressaltar que muitos autores vêm propondo a utilização de outros marcadores filogenéticos para a classificação taxonômica dos organismos além do gene rRNA 16S. Entre estes, proteínas ribossomais concatenadas já vem sendo utilizadas por alguns autores para um maior refinamento da classificação taxonômica e tal abordagem tem possibilitado a resolução de nós filogenéticos mais internos e um melhor posicionamento de algumas linhagens (MatteTailliez et al., 2002; Brochier-Armanet et al. 2008; Petitjean et al., 2014). A maior disponibilidade de genomas completos de archaeas, no futuro, permitirá que tais abordagens sejam utilizadas mais amplamente e talvez possibilitem o estabelecimento de um melhor posicionamento filogenético dos diferentes grupos do domínio Archaea.

Apesar das muitas discussões que envolvem a nomenclatura e o posicionamento taxonômico dos diferentes grupos de archaea atualmente, se formos considerar a nomenclatura apresentada pelo banco de dados Greengenes e considerada ainda por muitos autores, as sequências obtidas a partir do solo de Cerrado sensu stricto nesse trabalho foram todas classificadas como pertencentes ao filo Crenarchaeota. Tal resultado está de acordo com a literatura, já que trabalhos de Archaea em solo indicam que este filo é dominante em solos de diversas localidades (Ochsenreiter et al., 2003; Nicol et al., 2007; Timonen \& Bomberg, 2009). Estudos apontam ainda que o grupo I.1b é o mais abundante e ubíquo em solos (Auguet et al., 2010; Bates et al., 2011), enquanto organismos do grupo I.1c parecem estar mais associados a solos ácidos (Lehtorvita et al., 2009; Timonen e Bomberg, 2009), condição característica dos solos de Cerrado (Haridasan, 1994). Além disso, em outro levantamento de archaeas de solos de Cerrado Denso e Mata de Galeria previamente realizado por Catão e colaboradores (2013), também foram encontradas predominantemente sequências de organismos pertencentes aos grupos I.1b e I.1c.

A ocorrência de membros do filo Euryarchaeota parece ser rara em solos (Timonen \& Bomberg, 2009). Bates e colaboradores (2011) relataram que apenas 1,5\% das sequências de Archaea encontradas em seus estudos de biogeografia de ambientes terrestres pertenciam a este filo. Assim, o fato de não terem sido identificadas sequências pertencentes a esse filo em 
nossas amostras pode estar relacionado com a baixa ocorrência de organismos desse filo em solos. No entanto, também deve-se levar em consideração as limitações impostas pela metodologia de PCR empregada na obtenção de sequências ambientais, como por exemplo variações na eficiência dos experimentos de PCR devido a contaminantes no DNA total extraído ou ainda à especificidade do iniciador empregado na reação em relação ao gene alvo (Wintzingerode et al., 1997). Membros do filo Euryarchaeota já foram identificados em diferentes ambientes através da utilização desse mesmo par de iniciadores escolhido neste trabalho (21f/958r) (Bano et al., 2004; Etto et al., 2012), e inclusive em trabalhos anteriores de nosso grupo com sedimentos de lagoa de cerrado (Rodrigues et al., 2014). Assim, não é provável que os iniciadores utilizados tenham apresentado um viés para a amplificação de DNA apenas de membros do filo Crenarchaeota. No entanto, o experimento de PCR baseiase em uma reação enzimática competitiva, onde DNAs mais abundantes terão uma maior probabilidade de serem amplificados e, consequentemente, DNAs presentes em menor quantidade na amostra terão menor probabilidade de amplificação, podendo não ser amplificados (Forney et al., 2004). Desta forma, é possível que membros do filo Euryarchaeota sejam menos abundantes nos solos de Cerrado sensu stricto amostrados e por isso não tenham sido identificados na amostragem realizada.

\subsubsection{Análises de riqueza e alfa-diversidade}

O termo riqueza (richness) refere-se ao número de espécies presentes em uma determinada comunidade e é um dos conceitos mais antigos a ser levado em consideração para o cálculo de diversidade de um sistema biológico (Peet, 1974). A abundância refere-se à homogeneidade de distribuição (evenness) dos indivíduos entre as espécies e também deve ser considerada, juntamente com a riqueza, para o cálculo da diversidade (Melo, 2008). Assim, a diversidade de um sistema biológico baseia-se na riqueza e abundância das espécies encontradas no ambiente. A alfa-diversidade refere-se à diversidade de espécies encontrada em uma determinada área, ou seja, a diversidade local, enquanto a beta-diversidade é a diferença na composição de espécies entre diferentes áreas (Forney et al., 2004).

O conceito de espécie em procariotos é controverso e de difícil definição. No relatório do Comitê para a reavaliação da definição de espécie em bacteriologia de 2002 (Stackebrandt et al., 2002), colocou-se que uma definição de espécie pragmática, operacional e universalmente aplicável seria: "uma categoria que circunscreve (preferencialmente) um grupo genomicamente coerente de isolados/linhagens individuais compartilhando um alto 
grau de similaridade em várias características independentes, testadas comparativamente sob condições altamente padronizadas". Como revisado por Rosselló-Mora e Amann (2001), o conceito de espécie em procariotos foi se desenvolvendo juntamente com novas técnicas laboratoriais que permitiam a identificação de novas informações importantes acerca dos organismos. Esses autores ressaltam a importância da investigação e utilização de informações genômicas e fenotípicas para que uma classificação taxonômica mais acurada seja alcançada. Neste sentido, abordagens independentes de cultivo para estudos de filogenia e diversidade de procariotos em ambientes naturais, como as que utilizam o gene rRNA 16S, não trazem informações suficientes para que o conceito de espécie seja empregado de acordo com o exposto acima. Por estas razões, é utilizado então o conceito de unidades operacionais taxonômicas (OTUs), no qual os indivíduos podem ser definidos apenas em termos de características estatísticas covariantes, resultando em uma definição mais objetiva de unidades procarióticas (Rosselló-Mora \& Amann, 2001).

Ao se comparar sequências do gene de rRNA 16S, valores de distância entre estas podem ser utilizados para a classificação hierárquica das OTUs nas diferentes categorias taxonômicas. Em 1994, Stackebrandt e Goebel realizaram estudos envolvendo a similaridade entre rRNAs $16 \mathrm{~S}$ e relataram que uma similaridade de $97 \%$ ou mais entre as sequências indicaria que os organismos pertencem a uma mesma espécie. Schloss e Handelsman (2004) descreveram que, apesar de existirem controvérsias entre alguns autores, valores de distância (ou dissimilaridade) amplamente aceitos para classificações taxonômicas são: $3 \%$ de dissimilaridade para diferenciar espécies, 5\% para diferenciar gêneros, $10 \%$ para diferenciar famílias/classes e $20 \%$ para diferenciar filos. Em outras palavras, sequências de rRNA 16S que possuíssem 97\% de similaridade pertenceriam a uma mesma espécie, aquelas com 95\% de similaridade pertenceriam a um mesmo gênero, aquelas com $90 \%$ de similaridade pertenceriam a uma mesma família/classe e aquelas com $80 \%$ de similaridade pertenceriam a um mesmo filo. Como já mencionado, existem controvérsias quanto a esses valores, já que alguns autores consideram que uma similaridade de $99 \%$ entre as sequências seria necessária para estas serem consideradas como pertencentes a uma mesma espécie, considerando-se que organismos previamente reconhecidos como sendo de espécies diferentes apresentaram uma similaridade maior que 97\% entre suas sequências de rRNA 16S (Fox et al., 1992, Yassin et $a l .$, 2003). Neste trabalho, dada a sua ampla utilização em estudos de filogenia molecular e ecologia microbiana, os valores de dissimilaridade considerados para a diferenciação das OTUs em espécie, gênero, família/classe e filo foram 3, 5, 10 e $20 \%$ respectivamente. 
Para a realização das análises de alfa-diversidade, as sequências foram submetidas ao alinhamento múltiplo pelo programa ClustalX (Larkin et al., 2007) e posteriormente manualmente alinhadas por meio do programa Bioedit, retirando-se colunas geradas pelo algorítimo do programa e regiões de difícil alinhamento. Todas as sequências tiveram um tamanho igual ou superior a 400pb após o alinhamento final. Em seguida, foi gerada uma matriz de distância (método de average neighbor), que foi utilizada como base para o agrupamento das sequências nos táxons a partir dos coeficientes de dissimilaridade já mencionados. Para que as diferentes análises fossem conduzidas, o alinhamento foi realizado de três maneiras distintas: 1) com cada réplica de Controle e Queimada isoladamente, 2) com as réplicas de Controle em conjunto $(\mathrm{Ca}+\mathrm{Cb}+\mathrm{Cc})$ e de Queimada em conjunto $(\mathrm{Qa}+\mathrm{Qb}+$ Qc) e 3) também com todas as réplicas de Controle e de Queimada conjuntamente $(\mathrm{Ca}+\mathrm{Cb}+$ $\mathrm{Cc}+\mathrm{Qa}+\mathrm{Qb}+\mathrm{Qc})$.

Em nível de espécie (3\% de dissimilaridade), foram obtidos os seguintes números de OTUs em cada amostra: 17 em Ca, 10 em Cb, 12 em Cc, 13 em Qa, 12 em Qb e 12 em Qc. O número de sequências e OTUs obtidas em cada amostra, assim como o número de singletons (OTUs formadas por apenas uma sequência) podem ser vistos na Tabela 9. Ao compararmos o número de OTUs obtidas em cada amostra em relação ao número de sequências, pode-se concluir que a riqueza de archaeas no solo de Cerrado sensu stricto em ambas as condições estudadas é semelhante.

Tabela 9. Número de sequências, OTUs e singletons obtidos em cada amostra.

\begin{tabular}{cccc}
\hline Amostra & $\mathbf{N}^{0}$ de Sequências & OTUs & Singletons \\
\hline Ca & 80 & 17 & 7 \\
Cb & 79 & 10 & 0 \\
Cc & 74 & 12 & 6 \\
Qa & 82 & 13 & 4 \\
Qb & 101 & 12 & 4 \\
Qc & 50 & 12 & 4 \\
\hline
\end{tabular}

As análises de rarefação comparam a riqueza observada entre locais ou tratamentos que foram desigualmente amostrados e as curvas de rarefação resultam da média das curvas de acumulação, que são uma representação gráfica do número cumulativo de tipos observados versus o esforço amostral (Heck et al., 1975). Diferenças nas riquezas e abundâncias relativas das espécies (ou OTUs) na comunidade amostrada constituem a base da diferença na forma das curvas e, considerando-se que todas as comunidades apresentam um 
número finito de espécies, quanto mais bem amostrado é o local, mais próximo ao platô chegam as curvas (Hughes et al., 2001).

Para se avaliar a cobertura da amostragem, a nível de espécie (3\% de dissimilaridade), gênero (5\% de dissimilaridade), família/classe (10\% de dissimilaridade) e filo (20\% de dissimilaridade), foram construídas curvas de rarefação relacionando o número de sequências com o número de OTUs obtidas em cada amostra. As Figuras 8, 9 e 10 mostram as curvas referentes às réplicas de Controle $(\mathrm{Ca}, \mathrm{Cb}$ e $\mathrm{Cc})$ e as Figuras 11, 12 e 13 mostram as curvas referentes às réplicas de Queimada (Qa, $\mathrm{Qb}$ e Qc).

\section{$\mathrm{Ca}$}

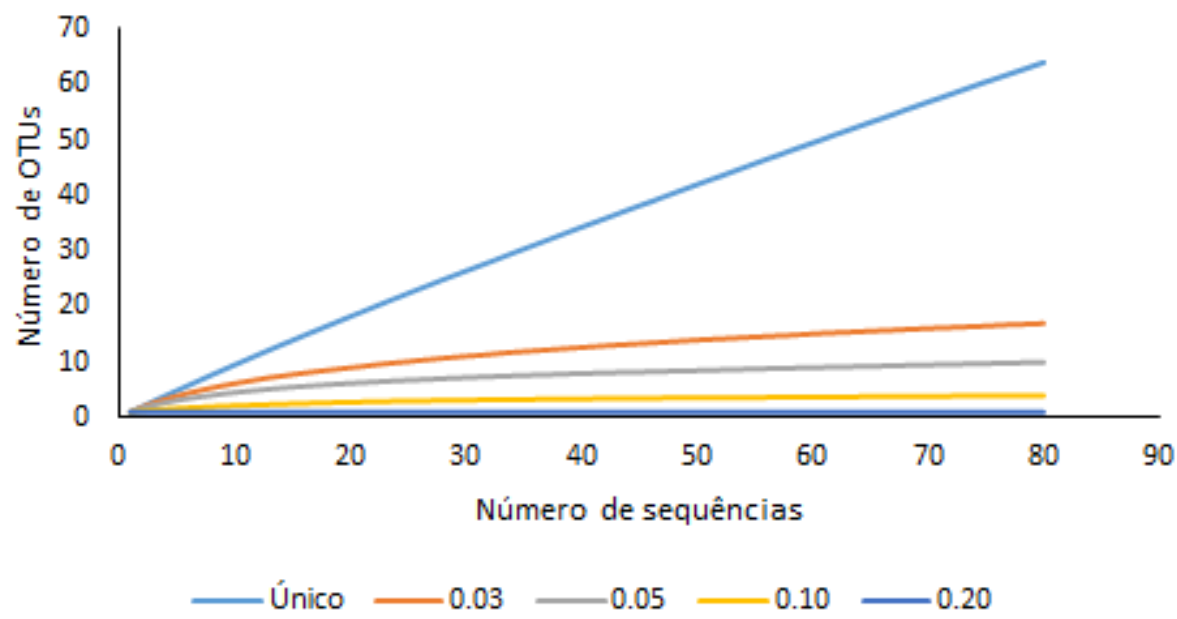

Figura 8. Curvas de rarefação obtidas para a amostra Ca para os valores de $3,5,10$ e $20 \%$ de dissimilaridade.

$\mathrm{Cb}$

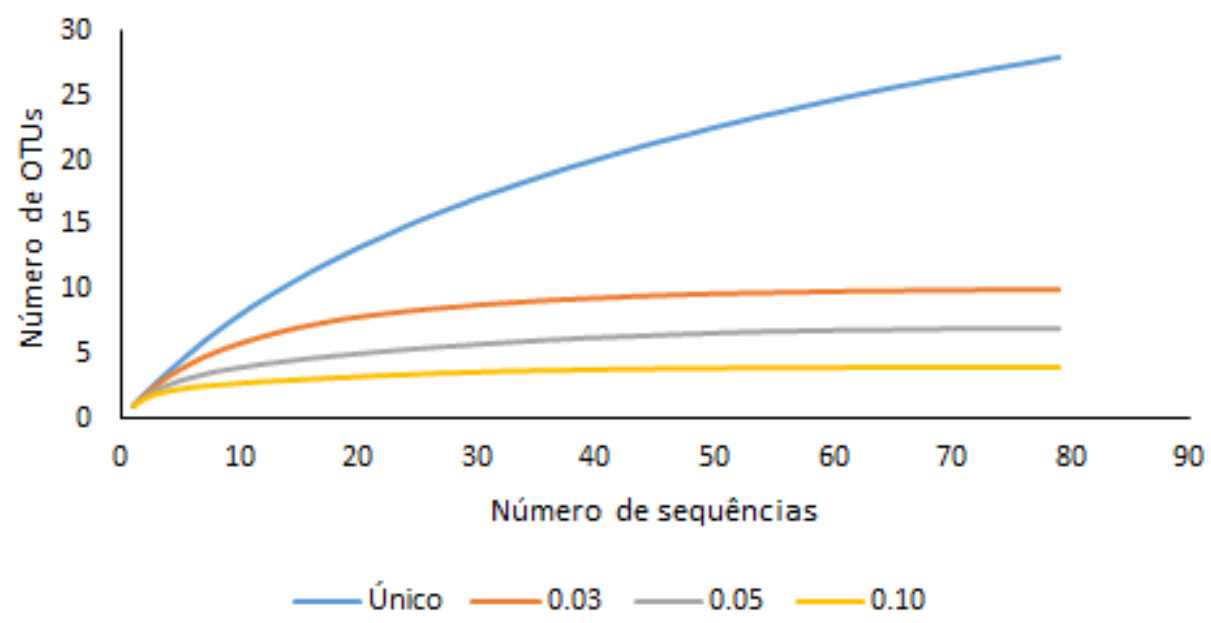

Figura 9. Curvas de rarefação obtidas para a amostra $\mathrm{Cb}$ para os valores de $3,5,10$ e $20 \%$ de dissimilaridade. 
Cc

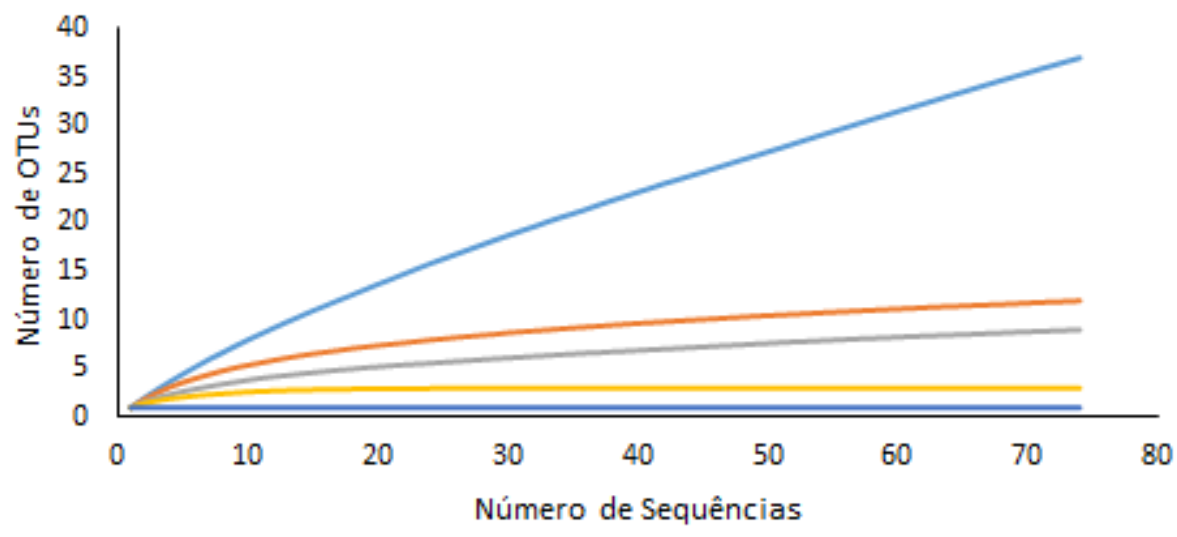

—único $-0.03-0.05-0.10-0.20$

Figura 10. Curvas de rarefação obtidas para a amostra Cc para os valores de 3,5, 10 e $20 \%$ de dissimilaridade.

Qa

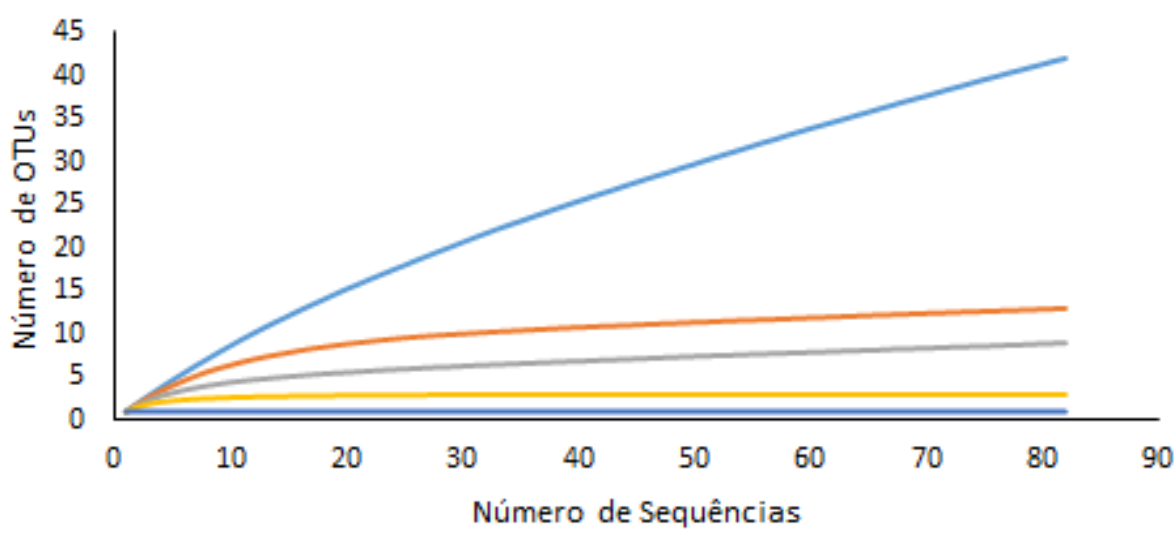

—Único $-0.03-0.05-0.10-0.20$

Figura 11. Curvas de rarefação obtidas para a amostra Qa para os valores de $3,5,10$ e $20 \%$ de dissimilaridade. 


\section{$\mathrm{Qb}$}

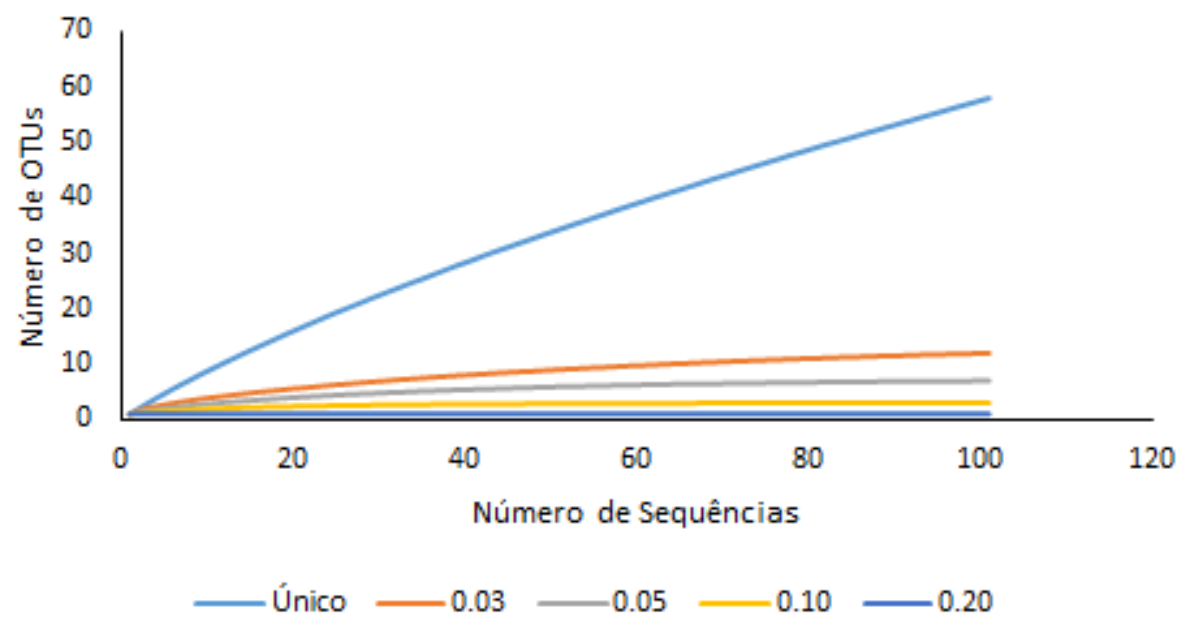

Figura 12. Curvas de rarefação obtidas para a amostra Qb para os valores de 3, 5, 10 e $20 \%$ de dissimilaridade.

Qc

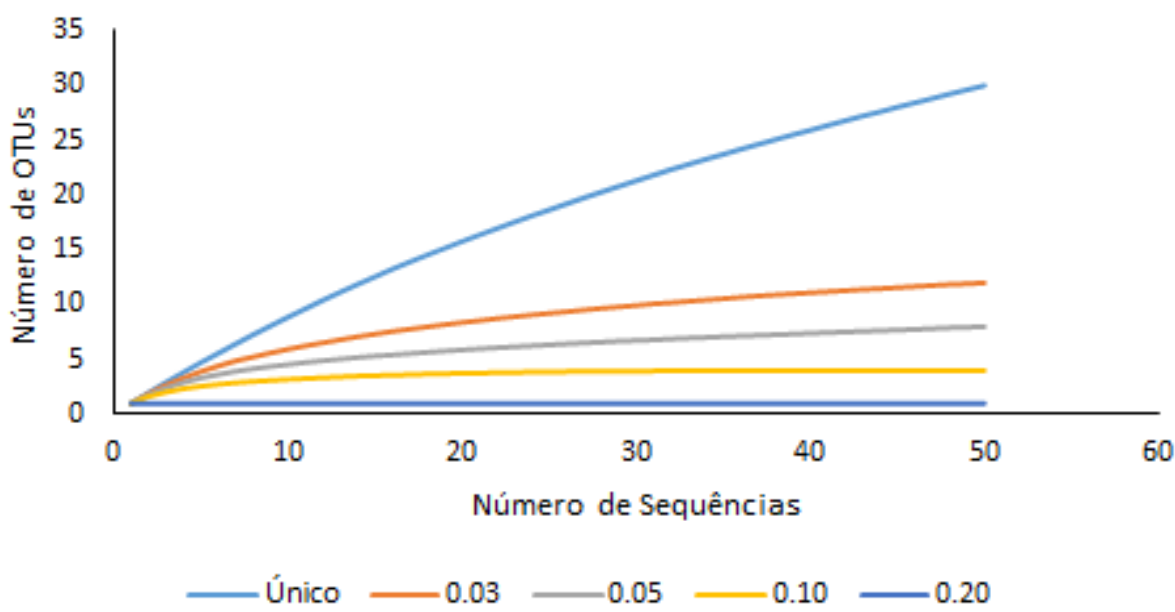

Figura 13. Curvas de rarefação obtidas para a amostra Qc para os valores de 3, 5, 10 e $20 \%$ de dissimilaridade.

As curvas de rarefação obtidas para todos os valores de dissimilaridade indicam que a amostragem foi suficiente em todos os níveis taxonômicos, para todas as réplicas de Controle e Queimada, já que todas as curvas atingiram o platô. Tal resultado evidencia a baixa riqueza da comunidade de Archaea nos solos de Cerrado sensu stricto em ambas as condições avaliadas (área queimada bienalmente e área protegida do fogo).

A baixa riqueza de archaeas em solos de outras fitofisionomias de Cerrado também foi evidenciada no trabalho de Catão e colaboradores (2013), no qual a comunidade de archaeas de solos de Cerrado Denso e Mata de Galeria também foi suficientemente amostrada a partir 
de um número ainda menor de sequências, sendo a comunidade do solo de Cerrado Denso ligeiramente mais rica do que a de Mata de Galeria. Por outro lado, Araújo e colaboradores (2012) constataram que, apesar do alto número de sequências de Bacteria obtidas, a amostragem não foi suficiente para descrever a comunidade de bactérias em solos de Cerrado sensu stricto e de outras fitofisionomias, demonstrando a extensa diversidade desses organismos em solos de cerrados. Outros estudos ambientais com rRNA 16S também indicam uma baixa diversidade de archaeas em relação àquela observada para bactérias na maioria dos ambientes analisados, sugerindo que as archaeas formam comunidades pouco ricas nesses ambientes (Robertson et al., 2009; Bates et al., 2011).

Aller e Kemp (2008) compararam bibliotecas genômicas de Archaea e Bacteria provenientes de diversos ambientes e observaram que, apesar de archaeas contribuírem para uma significativa proporção do total de filotipos de procariotos na maioria dos ambientes pesquisados até hoje, a riqueza estimada de archaeas é quase sempre mais baixa que a de bactérias. Além disso, os autores notaram que o número de filotipos observados não é correlacionado com o tamanho da biblioteca genômica para archaeas, sugerindo que bibliotecas grandes nem sempre são melhores para amostrar archaeas em novos ambientes, enquanto que para bactérias há uma correlação entre os filotipos observados e o tamanho da biblioteca, fazendo com que poucas bibliotecas tenham amostrado a diversidade bacteriana de forma suficiente.

É importante ressaltar ainda que devido aos vieses introduzidos pelos iniciadores escolhidos na PCR, comunidades microbianas (ou alguns grupos filogenéticos) podem ser mal representadas, fazendo com que sua real riqueza seja de difícil determinação (Forney et al., 2004). Hong e colaboradores (2009) compararam a riqueza microbiana obtida em uma amostra a partir da utilização de diferentes técnicas de extração de DNA total combinadas a diferentes pares de iniciadores na PCR e mostraram que os diferentes métodos levam a identificação de conjuntos microbianos específicos diferentes entre si, influenciando na riqueza inferida. Assim, um maior número de sequências de archaea conhecidas, que poderão auxiliar no desenvolvimento de novos iniciadores, e a utilização de diferentes iniciadores seriam importantes para uma melhor análise da riqueza das comunidades de Archaea.

Apesar das dificuldades relacionadas à determinação de riqueza e diversidade de microrganismos, abordagens estatísticas podem ser utilizadas para a realização de estimativas. Inicialmente desenvolvidos para as análises de alfa e beta-diversidade de organismos macroscópicos, existem alguns índices de riqueza e diversidade que podem ser adequados e vêm sendo utilizados em estudos de comunidades microbianas (Hughes et al., 2001). Chao1 
(Chao, 1984) e ACE (Abundance-based Coverage Estimators) (Chao \& Lee, 1992) são índices não-paramétricos que comparam a proporção de OTUs já observadas anteriormente com aquelas observadas apenas uma vez, adicionando um fator de correção ao número de OTUs observadas. O cálculo do índice Chao1 leva em consideração o número de OTUs observadas (Sobs), o número de singletons (OTUs identificadas apenas uma vez) e o número de doubletons (OTUs identificadas duas vezes), enquanto o índice ACE incorpora dados de espécies identificadas menos de dez vezes, ao invés de singletons e doubletons (Hughes et al., 2001). Por serem calculados considerando fatores diferentes, não é incomum que esses índices apresentem valores diferentes ao serem empregados na análise de riqueza de uma mesma comunidade microbiana.

Existem também índices para estimar a diversidade das comunidades, que levam em consideração não só o número de espécies encontradas (riqueza), mas também a abundância dos organismos. O índice Shannon (Shannon \& Weaver, 1949) indica qual comunidade é mais diversa, com seu valor aumentando conforme a riqueza de espécies aumenta e conforme a distribuição dos indivíduos entre as espécies vai se tornando homogênea. Outro índice utilizado, o Simpson (Simpson, 1949), indica a dominância das espécies e reflete a probabilidade de dois indivíduos que pertencem à mesma espécie serem aleatoriamente escolhidos. Seus valores variam de 0 a 1 , sendo que seu valor aumenta conforme a diversidade diminui, ou em outras palavras, quanto mais próximo de 1 menor é a diversidade estimada para aquela comunidade (Lemos et al., 2011).

Para se comparar as comunidades de Archaea nos solos de Cerrado sensu stricto submetidos às duas condições, foram calculados índices de riqueza (Chao1 e ACE) e diversidade (Shannon e Simpson) para cada réplica de Controle ( $\mathrm{Ca}, \mathrm{Cb}, \mathrm{Cc})$ e Queimada (Qa, Qb e Qc). Os valores obtidos para cada um dos índices de riqueza e diversidade assim como o número de OTUs observados (Sobs) e a cobertura da amostragem em cada um dos coeficientes de dissimilaridade podem ser vistos na Tabela 10. A cobertura da amostragem mede o quão suficientemente o ambiente foi amostrado, indicando a porcentagem de indivíduos (para cada nível de dissimilaridade) que foram amostrados na comunidade microbiana (Lemos et al., 2011). 
Tabela 10. Índices de riqueza (Chao1 e ACE), diversidade (Shannon e Simpson), número de OTUs observadas (Sobs) e a cobertura para cada uma das réplicas de controle $(\mathrm{Ca}, \mathrm{Cb}$ e $\mathrm{Cc})$ e Queimada (Qa, Qb e Qc) em cada um dos coeficientes de dissimilaridade.

\begin{tabular}{|c|c|c|c|c|c|c|c|}
\hline Amostra & Dissimilaridade & Sobs & Chao1 & ACE & Shannon & Simpson & Cobertura \\
\hline \multirow{4}{*}{$\begin{array}{c}\text { Ca } \\
\text { (80 sequências) }\end{array}$} & $3 \%$ & 17 & 24,000 & 23,645 & 2,287 & 0,129 & $91,25 \%$ \\
\hline & $5 \%$ & 10 & 16,000 & 13,878 & 1,635 & 0,270 & $95,00 \%$ \\
\hline & $10 \%$ & 4 & 4,000 & 4,642 & 0,555 & 0,729 & $98,75 \%$ \\
\hline & $20 \%$ & 1 & 1,000 & 0,000 & 0,000 & 1,000 & $100,00 \%$ \\
\hline \multirow{4}{*}{$\begin{array}{c}\text { Cb } \\
\text { (79 sequências) }\end{array}$} & $3 \%$ & 10 & 10,000 & 10,000 & 2,073 & 0,135 & $100,00 \%$ \\
\hline & $5 \%$ & 7 & 7,000 & 7,000 & 1,466 & 0,280 & $100,00 \%$ \\
\hline & $10 \%$ & 4 & 4,000 & 4,000 & 0,986 & 0,417 & $100,00 \%$ \\
\hline & $20 \%$ & 2 & 2,000 & 2,000 & 0,161 & 0,926 & $100,00 \%$ \\
\hline \multirow{4}{*}{$\begin{array}{c}\text { Cc } \\
\text { (74 sequências) }\end{array}$} & $3 \%$ & 12 & 14,000 & 15,934 & 1,951 & 0,179 & $94,59 \%$ \\
\hline & $5 \%$ & 9 & 12,000 & 22,031 & 1,345 & 0,385 & $94,59 \%$ \\
\hline & $10 \%$ & 3 & 3,000 & 3,000 & 0,793 & 0,547 & $100,00 \%$ \\
\hline & $20 \%$ & 1 & 1,000 & 0,000 & 0,000 & 1,000 & $100,00 \%$ \\
\hline \multirow{4}{*}{$\begin{array}{c}\text { Qa } \\
\text { (82 sequências) }\end{array}$} & $3 \%$ & 13 & 19,000 & 16,135 & 2,276 & 0,107 & $95,12 \%$ \\
\hline & $5 \%$ & 9 & 15,000 & 26,198 & 1,615 & 0,241 & $95,12 \%$ \\
\hline & $10 \%$ & 3 & 3,000 & 3,000 & 0,936 & 0,417 & $100,00 \%$ \\
\hline & $20 \%$ & 1 & 1,000 & 0,000 & 0,000 & 1,000 & $100,00 \%$ \\
\hline \multirow{4}{*}{$\begin{array}{c}\text { Qb } \\
\text { (101 sequências) }\end{array}$} & $3 \%$ & 12 & 13,500 & 15,519 & 1,433 & 0,386 & $96,03 \%$ \\
\hline & $5 \%$ & 7 & 7,000 & 7,731 & 0,889 & 0,606 & $99,00 \%$ \\
\hline & $10 \%$ & 3 & 3,000 & 3,000 & 0,453 & 0,768 & $100,00 \%$ \\
\hline & $20 \%$ & 1 & 1,000 & 0,000 & 0,000 & 1,000 & $100,00 \%$ \\
\hline \multirow{4}{*}{$\begin{array}{c}\text { Qc } \\
\text { (50 sequências) }\end{array}$} & $3 \%$ & 12 & 14,000 & 16,111 & 2,112 & 0,136 & $92,00 \%$ \\
\hline & $5 \%$ & 8 & 11,000 & 11,980 & 1,655 & 0,213 & $94,00 \%$ \\
\hline & $10 \%$ & 4 & 4,000 & 4,000 & 1,112 & 0,367 & $100,00 \%$ \\
\hline & $20 \%$ & 1 & 1,000 & 0,000 & 0,000 & 1,000 & $100,00 \%$ \\
\hline
\end{tabular}

Como já mencionado, todas as amostras, tanto de Controle quanto de Queimada, apresentaram números próximos de OTUs, indicando uma riqueza muito semelhante nas comunidades do solo em ambas as condições. Nota-se também que há um baixo número de OTUs observadas nas amostras até mesmo para o nível de espécie, o que sugere uma baixa riqueza de archaeas nessas comunidades.

As coberturas foram altas em todas as amostras, sendo superiores a 90\% em nível de espécie em todas, indicando que a amostragem foi adequada para a descrição do ambiente analisado. Os valores de Chao1 e ACE obtidos corroboram que a riqueza de archaeas para esses solos foi praticamente coberta. No entanto, é importante ressaltar que análises nãoparamétricas como a desses índices, são influenciadas diretamente pelo tamanho da amostragem e, consequentemente, amostragens pequenas podem levar a baixas estimativas de riqueza (Hughes et al., 2001). Desta forma, não podemos descartar a possibilidade que a 
riqueza de Archaea em solos de Cerrado sensu stricto estimada por esses índices possa estar sendo subestimada devido ao número de sequências empregadas na análise.

Quanto aos índices Shannon e Simpson, estes indicam que a diversidade é muito semelhante entre as comunidades do solo de Cerrado sensu stricto que sofre queimadas bienais e o que não sofre, sugerindo que essas queimadas periódicas não influenciam na diversidade das archaeas do solo de cerrado. Os valores de Simpson para a maioria das amostras ficaram mais próximos de 1 para os níveis taxonômicos de família/classe (10\%) e gênero (5\%), sugerindo que a diversidade nesses níveis é baixa. No entanto, a nível de espécie (3\%), os valores obtidos são mais próximos de 0 (com exceção de Qb), o que indicaria uma maior diversidade para esse nível taxonômico na maioria das amostras. Considerando-se que a riqueza estimada para as amostras é baixa, a diversidade dessas comunidades deve estar mais relacionada à abundância relativa entre os organismos (Lemos et al., 2011).

Com o intuito de se verificar quantas OTUs eram compartilhadas entre as diferentes réplicas de Controle, diagramas de Venn foram construídos a partir de um alinhamento múltiplo das sequências de $\mathrm{Ca}, \mathrm{Cb}$ e $\mathrm{Cc}$. $\mathrm{O}$ mesmo foi feito com as sequências das réplicas de Queimada, sendo construídos diagramas de Venn a partir de um alinhamento múltiplo das sequências de Qa, Qb e Qc. Ambos os alinhamentos tiveram um número final de 233 sequências, não sendo necessária a retirada de nenhuma sequência a mais para esse passo. Apenas os diagramas a nível de espécie (3\%) são apresentados (Figuras 14 e 15) já que, tendo em vista o baixo número de OTUs encontrados para os demais níveis, consideramos que os diagramas em nível de espécie seriam mais ilustrativos.

Das 31 OTUs observadas em todas as réplicas de Controle, apenas 5 são compartilhadas entre todas. No entanto, a similaridade entre as réplicas da área Controle torna-se evidente quando observa-se que a grande maioria das sequências estão representadas por essas 5 OTUs, sendo que do total de 233 sequências, 168 são compartilhadas por $\mathrm{Ca}, \mathrm{Cb}$ e Cc. Quanto às réplicas de Queimada, das 21 OTUs observadas, 7 são compartilhadas entre as três réplicas e, também neste caso, essas OTUs são as mais representativas, consistindo em 146 sequências dentre as 233. Porém, é evidente uma maior semelhança entre Qa e Qb, já que essas duas réplicas compartilham entre si outras 71 sequências que não foram identificadas em Qc. As OTUs exclusivas em cada réplica são formadas majoritariamente por singletons ou doubletons. 


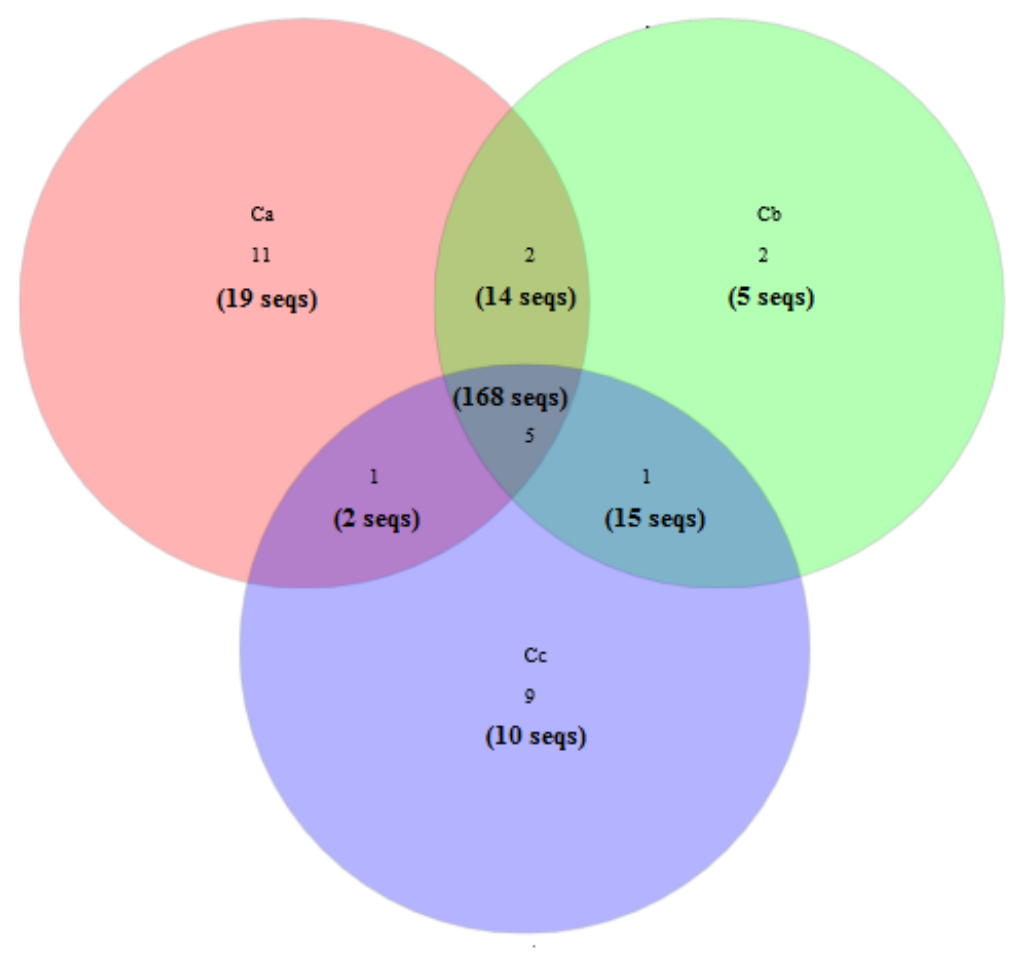

Figura 14. Diagrama de Venn representando as OTUs exclusivas e compartilhadas a nível de espécie (3\%) nas réplicas de Controle $\mathrm{Ca}, \mathrm{Cb}$ e Cc. O número de sequências em cada uma das situações é indicado. Seqs: sequências.

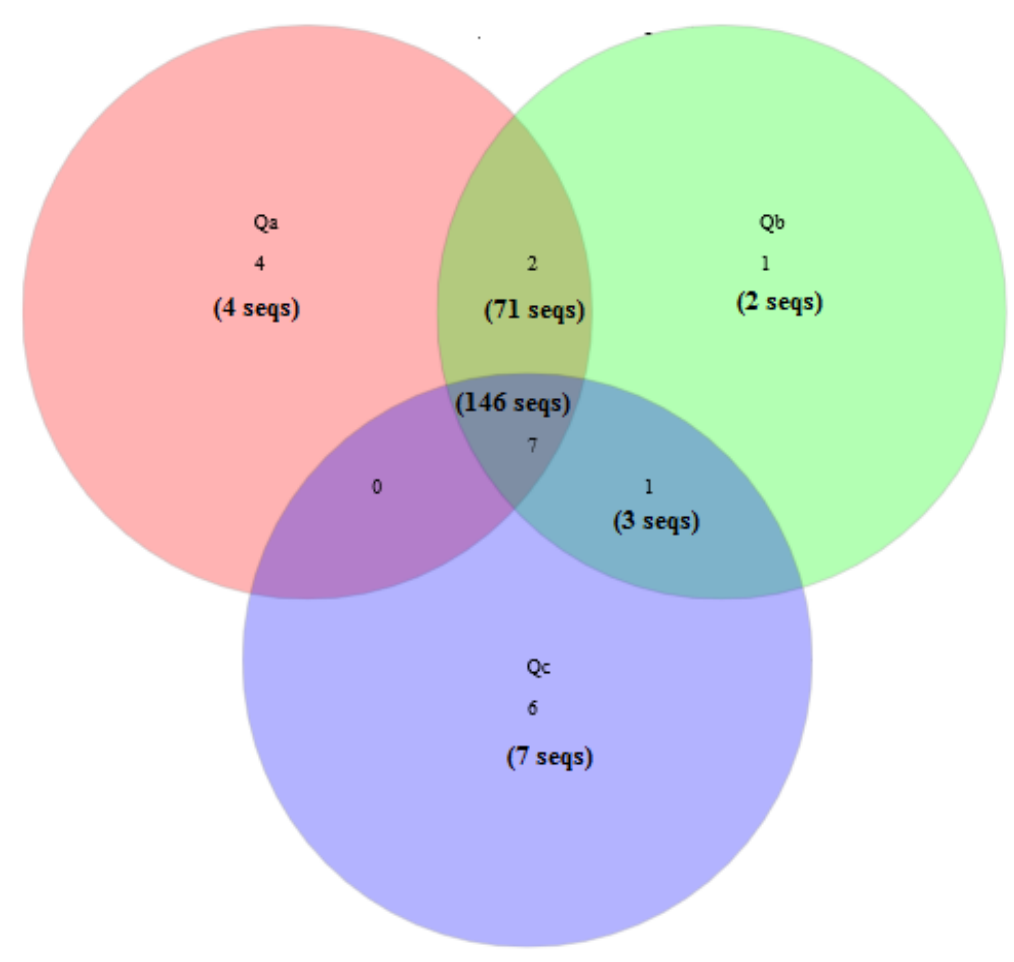

Figura 15. Diagrama de Venn representando as OTUs exclusivas e compartilhadas a nível de espécie (3\%) nas réplicas de Queimada Qa, Qb e Qc. $\mathrm{O}$ número de sequências em cada uma das situações é indicado. Seqs: sequências. 
Devido à impossibilidade da construção de um diagrama de Venn de fácil interpretação com seis amostras e visando a visualização da quantidade de OTUs compartilhadas entre Controle e Queimada, as réplicas de cada amostra foram alinhadas conjuntamente $(\mathrm{Ca}+\mathrm{Cb}+\mathrm{Cc}$ e $\mathrm{Q} a+\mathrm{Qb}+\mathrm{Qc})$ e consideradas como sendo uma única amostra de Controle e uma única amostra de Queimada. Um diagrama de Venn foi então confeccionado com essas duas amostras (Figura 16) e, novamente, o número de sequências representadas pelas OTUs exclusivas e compartilhadas foram apresentados.

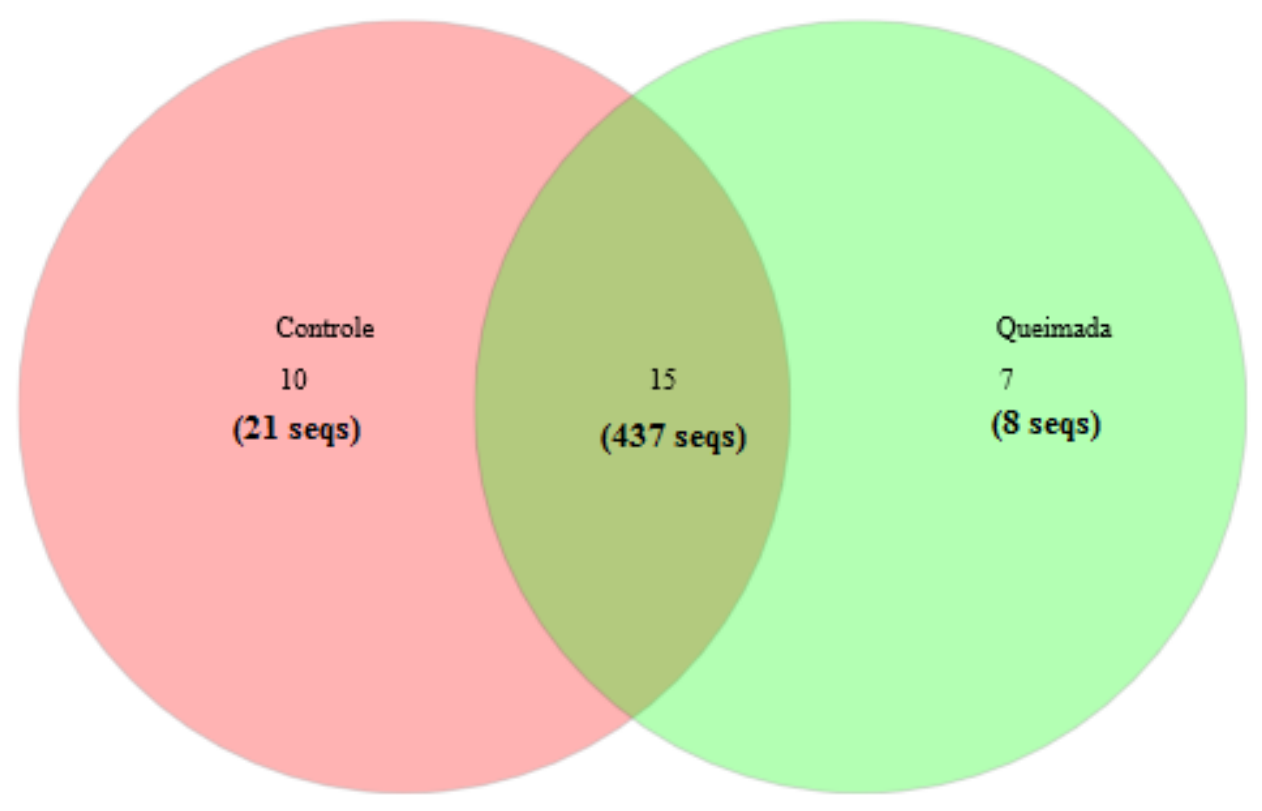

Figura 16. Diagrama de Venn representando as OTUs exclusivas e compartilhadas a nível de espécie (3\%) nas amostras de Controle e Queimada, sendo Controle $=\mathrm{Ca}+\mathrm{Cb}+\mathrm{Cc}$ e Queimada $=\mathrm{Q} a+Q b+Q c$. O número de sequências em cada uma das situações é indicado. Seqs: sequências.

Como pode ser visto na Figura 16, o número de OTUs compartilhadas entre as amostras (15) é maior que o número de OTUs exclusivas em cada uma das amostras (10 exclusivas de Controle e 7 de Queimada). No entanto, a similaridade entre as amostras de Controle e Queimada torna-se realmente evidente ao observarmos o número de sequências representadas pelas OTUs compartilhadas, sendo 437 sequências compartilhadas de um total de 466. A grande sobreposição de sequências nas amostras Controle e Queimada, juntamente com os resultados das demais análises de alfa diversidade já apresentados, indica a grande 
similaridade de diversidade entre as comunidades de Archaea de solo de Cerrado sensu stricto com regime de queima bienal e o controle protegido do fogo.

\subsubsection{Análises de beta-diversidade}

Como já mencionado, a beta-diversidade refere-se à análise da diferença de composição de espécies entre diferentes áreas (Forney et al., 2004). Ela pode ser estimada por meio de testes estatísticos baseados em divergência como o J-Libshuff (Schloss et al., 2004) e o Unifrac (Unique Fraction metric) (Lozupone et al., 2007). O J-Libshuff é uma extensão do Libshuff (Singleton et al., 2001), que aumenta a acurácia das estimativas por utilizar a forma integral de algumas estatísticas realizadas no teste.

O Libshuff foi um dos primeiros testes de beta-diversidade desenvolvidos e utiliza distâncias entre os nucleotídeos para determinar se duas comunidades são significativamente diferentes (Singleton et al., 2001). A cobertura da biblioteca de sequências da comunidade X $(\mathrm{Cx})$, definida como a porcentagem de sequências em $\mathrm{X}$ que não são singletons, é calculada após o agrupamento das sequências com uma faixa de possíveis níveis de distância entre elas. Os valores obtidos para X são então comparados àqueles obtidos para uma outra comunidade, Y. A cobertura da biblioteca Cxy é calculada como sendo a fração de sequências que estão em X que também estão em Y (Lozupone \& Knight, 2008). Vale ressaltar que no teste são realizadas duas comparações entre um par de bibliotecas, Cxy e Cyx, e que resultados diferentes serão gerados. Assim, este teste compara as comunidades de par em par.

No teste, são gerados dois valores de $\rho$ para cada comparação e uma correção entre os valores é necessária, utilizando-se correção de Bonferroni. Tal correção indica a significância entre as amostras, sendo que se o valor de $\rho$ for menor que o valor de $\rho$ corrigido, as comunidades apresentam diferença significativa (Schloss et al., 2004).

O teste de hipótese $\int$-Libshuff foi empregado para comparar as comunidades microbianas das diferentes amostras e os resultados obtidos podem ser vistos na Tabela 11. 
Tabela 11. Teste de hipótese $\int$-Libshuff entre as réplicas de Controle e Queimada.

\begin{tabular}{|c|c|c|c|}
\hline Amostra & dCXYScore & Valor $\rho$ & $\begin{array}{c}\text { Significância } \\
\text { (se } \rho=0,05 / 12=0,0041)\end{array}$ \\
\hline $\mathrm{Cc}-\mathrm{Cb}$ & 0.00016865 & 0.2402 & Não \\
\hline $\mathrm{Cb}-\mathrm{Qa}$ & 0.00059076 & 0.0049 & Não \\
\hline $\mathrm{Qa}-\mathrm{Cb}$ & 0.00019882 & 0.1520 & Não \\
\hline $\mathrm{Cb}-\mathrm{Qb}$ & 0.00110701 & 0.0009 & Não \\
\hline $\mathrm{Qb}-\mathrm{Cb}$ & 0.01602317 & $<0.0001$ & Significativo \\
\hline $\mathrm{Cb}-\mathrm{Qc}$ & 0.00132896 & 0.0230 & Não \\
\hline $\mathrm{Qc}-\mathrm{Cb}$ & 0.00044904 & 0.2174 & Não \\
\hline $\mathrm{Cc}-\mathrm{Qa}$ & 0.00008606 & 0.3100 & Não \\
\hline $\mathrm{Qa}-\mathrm{Cc}$ & 0.00102556 & 0.0006 & Não \\
\hline $\mathrm{Cc}-\mathrm{Qb}$ & 0.00032956 & 0.0019 & Não \\
\hline $\mathrm{Qb}-\mathrm{Cc}$ & 0.01005823 & $<0.0001$ & Significativo \\
\hline $\mathrm{Cc}-\mathrm{Qc}$ & 0.00037071 & 0.0839 & Não \\
\hline Qc-Cc & 0.00051296 & 0.0181 & Não \\
\hline Qa-Qb & 0.00021758 & 0.0095 & Não \\
\hline Qb-Qa & 0.00060623 & 0.0036 & Não \\
\hline Qa-Qc & 0.00075546 & 0.0284 & Não \\
\hline Qc-Qa & 0.00033817 & 0.0811 & Não \\
\hline Qb-Qc & 0.01171937 & $<0.0001$ & Significativo \\
\hline Qc-Qb & 0.00041351 & 0.1713 & Não \\
\hline
\end{tabular}

Como pode ser visto na Tabela 11, na maioria das comparações realizadas não houve diferença significativa entre as comunidades, tanto nas comparações das réplicas de Controle entre si e de Queimada entre si quanto nas comparações entre réplicas de Controle e Queimada. Tal resultado reforça que há grande similaridade entre as comunidades de Archaea dos solos de Cerrado sensu stricto protegido do fogo e submetido a queimadas periódicas.

No entanto, é interessante notar que as únicas comparações em que foram encontradas diferenças significativas foram comparações que envolviam a réplica $\mathrm{Qb}$ em relação a outras (Qb-Cb, Qb-Cc e Qb-Qc). Tal fato indica uma diferença na comunidade de $\mathrm{Qb}$ em relação às demais. Nas classificações taxonômicas obtidas pelo Greengenes também já havia sido constatada uma diferença nesta réplica especificamente em relação as demais, já que esta réplica foi a única a apresentar uma expressiva quantidade de sequências classificadas como do grupo I.1b de Thaumarchaeota em relação àquelas do grupo I.1c. Esta diferença poderia indicar que esta réplica foi coletada em um ponto com alguma peculiaridade ambiental específica, como por exemplo a proximidade com a raiz de uma determinada planta ou 
atividades da fauna local próximo a este ponto de coleta. Medidas de parâmetros físicoquímicos do solo de cada réplica poderiam ter auxiliado no esclarecimento desta questão, já que diferenças nos parâmetros deste ponto de coleta em relação aos demais poderiam influenciar na comunidade microbiana.

Outro teste que pode ser utilizado para se estimar as diferenças de diversidade entre comunidades é o Unifrac (Unique Fraction metric) (Lozupone et al., 2007). Existem duas versões deste teste: o Unweighted Unifrac e o Weighted Unifrac. O primeiro é uma medida qualitativa da beta-diversidade, já que seu algoritmo leva em conta apenas a presença ou ausência das linhagens na amostra, não considerando o número de sequências de cada linhagem, ou seja, a abundância relativa. Já o Weighted Unifrac é considerado uma medida quantitativa de beta-diversidade, pois além de detectar mudanças na composição dos táxons presentes na amostra, o algoritmo também detecta mudanças no número de sequências de cada táxon (Lozupone \& Knight, 2008). Uma grande vantagem destes testes consiste na capacidade de comparar várias comunidades simultaneamente e não apenas de par em par, como o $\int$-Libshuff. Os resultados obtidos nestes testes podem ser visualizados em Gráficos de Análise das Principais Coordenadas (PCoA).

Para se analisar as diferenças nas comunidades das réplicas de Controle e Queimada, coordenas para o PCoA foram geradas pelo comando Weighted Unifrac no programa Mothur e o gráfico foi construído utilizando-se o programa PAST3 (Hammer et al., 2001). O Gráfico obtido está mostrado na Figura 17. 


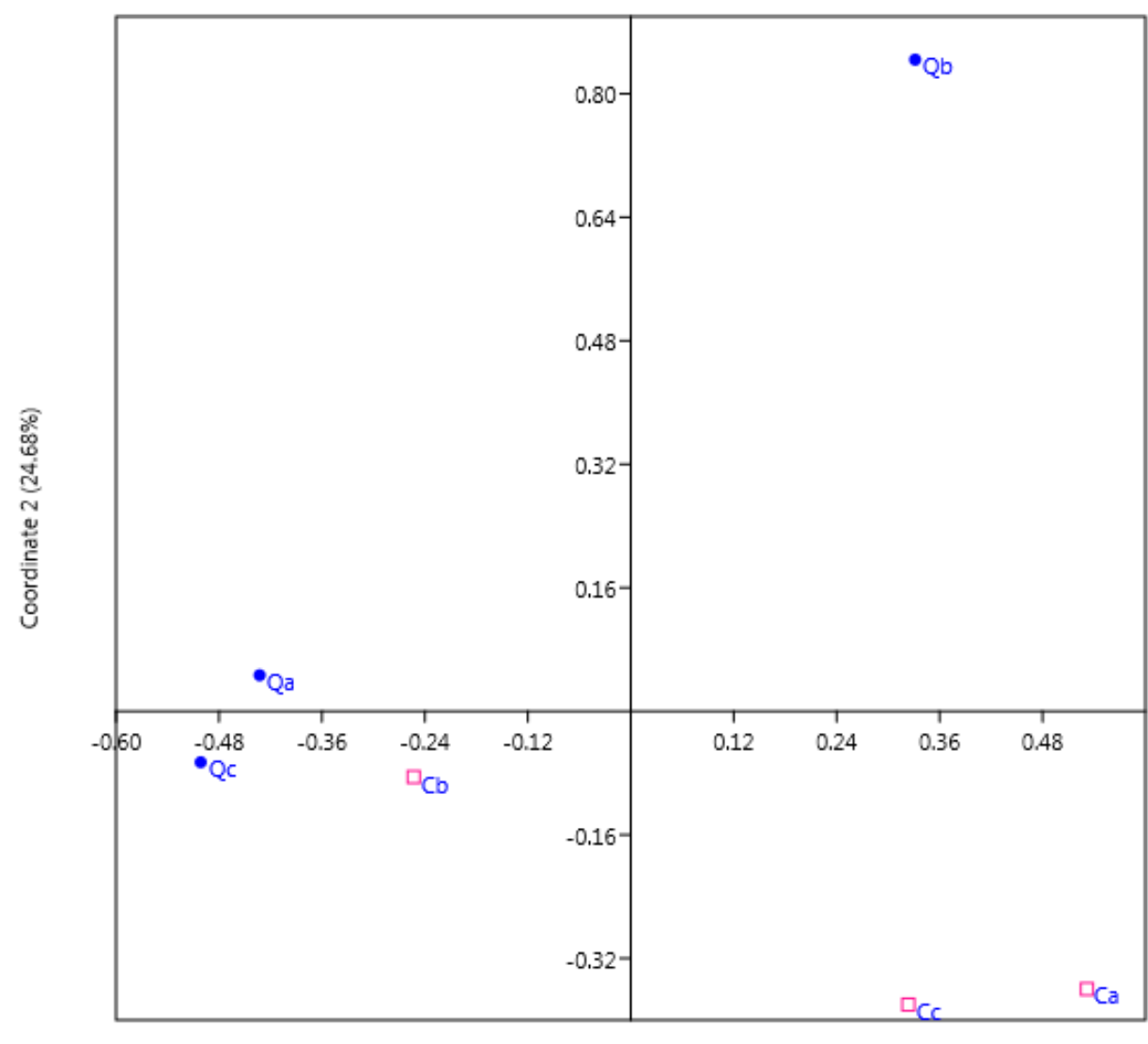

Coordinate $1(31.93 \%)$

Figura 17. Gráfico de Análise de Principais Coordenadas (PCoA) gerado através de coordenadas obtidas pelo comando Weighted Unifrac no programa Mothur e construído no programa PAST3. As réplicas de Controle estão indicadas por pontos rosas, enquanto as réplicas de Queimada estão em azul.

No PCoA foi possível observar que as réplicas de controle Ca e Cc encontram-se mais próximas entre si do que em relação a $\mathrm{Cb}$. As réplicas $\mathrm{Cb}$, Qa e Qc também se encontram próximas umas das outras. Curiosamente, a réplica $\mathrm{Qb}$ é a que se encontra mais distante de todas as outras réplicas. Esse resultado é congruente ao observado no f-Libshuff, cujos resultados indicam que esta mesma réplica $(\mathrm{Qb})$ apresenta diferenças significativas com relação a outras amostras e talvez também esteja relacionado a peculiaridade que foi observada quanto a classificação pelo Greengenes das sequências desta réplica em relação as demais.

É interessante ressaltar que houve um agrupamento entre duas réplicas de cada condição no PCoA (Ca-Cc e Qa-Qc). Vale ainda apontar que não foram detectadas diferenças significativas entre as duas condições no que se diz respeito à riqueza. No entanto, o Weighted Unifrac leva em consideração a abundância dos táxons, além da presença ou 
ausência destes nas amostras. Desta forma, ao revelar um certo agrupamento entre réplicas da mesma condição, este teste poderia estar indicando que, apesar de não haver diferenças significativas entre as amostras de Controle e Queimada em termos de riqueza, a abundância dos organismos encontrados em cada condição pode ser diferente, levando a diferenças entre as réplicas de ambas as condições. As réplicas que não seguiram este padrão foram Qb, caso já discutido acima, e Cb. No entanto, devido a condições locais dos pontos de coleta que podem influenciar a comunidade microbiana, é comum algumas réplicas destoarem das outras em trabalhos ambientais (Prosser, 2010).

\subsubsection{4. Árvores filogenéticas}

As árvores filogenéticas são amplamente utilizadas para inferir relações evolutivas entre os organismos e podem ser construídas com base no alinhamento múltiplo de sequências de nucleotídeos. Devido à sua natureza altamente conservada e à grande disponibilidade de sequências em bancos de dados atualmente, o rRNA 16S é comumente utilizado para a construção de árvores filogenéticas de procariotos (Robertson et al., 2005; Schleper et al., 2005; Zaneveld et al., 2010).

Para a construção de árvores filogenéticas com as sequências de rRNA 16S obtidas a partir das amostras de solo de Cerrado sensu stricto em ambas as condições estudadas, foi realizado um alinhamento múltiplo entre as sequências obtidas neste trabalho e sequências disponíveis nos bancos de dados. Para cada uma das condições analisadas (Cerrado sensu stricto controle e queimado bienalmente) foi construída uma árvore filogenética (Figuras 18A e 18B), utilizando-se as sequências de OTUs representativas a nível de espécie (3\% de dissimilaridade) obtidas pelo programa Mothur (Schloss et al., 2009). Com o intuito de observar o posicionamento filogenético das sequências representativas de Controle e Queimada conjuntamente, uma terceira árvore foi construída a partir do alinhamento múltiplo das sequências representativas das réplicas $\mathrm{Ca}, \mathrm{Cb}, \mathrm{Cc}, \mathrm{Qa}, \mathrm{Qb}$ e Qc juntas (Figura 19). Nesta árvore também foram utilizadas as sequências de OTUs representativas em nível de espécie (3\% de dissimilaridade). Os singletons foram incluídos nas árvores exclusivas de Controle ou de Queimada (Figura 18). No entanto, os singletons não foram incluídos na árvore com as sequências representativas de Controle e Queimada em conjunto (Figura 19), no intuito de proporcionar uma visualização mais clara da árvore.

Sequências de isolados de Archaea pertencentes aos filos Crenarchaeaota e Euryarchaeota foram obtidas no banco de dados do NCBI e alinhadas às sequências das 
OTUs representativas de Controle e Queimada para a construção das árvores filogenéticas. Os isolados selecionados para esses filos, juntamente com o número de acesso de suas sequências no banco de dados, foram: Haloferax volcanii (KC354397.1), Methanosarcina acetivorans (NR044724.1), Methanosaeta thermophila (NR028157.1), Pyroccocus furiosous (AB603518.1) - Filo Euryarchaeota; Pyrobaculum islandicum (L07511.1), Ignicoccus pacificus (AJ271794.1), Sulfolobus solfactarius (XO3235.1), Termoproteus neutrophilus (AB009618.1), Thermocladium modestius (AB005296.1), Fervidicoccus fontis (NR116054.1), Caldisphaera lagunensis (NR102472.1), Ignisphaera aggregans (NR102869.1) - Filo Crenarchaeota. Como nenhuma sequência apresentou alinhamento significativo com membros do filo Euryarchaeota (anteriormente já constatado pela classificação do Greengenes) e objetivando proporcionar uma melhor visualização das árvores com sequências só de Controle (Figura 18A) ou só de Queimada (Figura 18B), apenas os organismos Methanosarcina acetivorans e Methanosaeta thermophila foram incluídos nestas, sendo os demais euryarchaeotas incluídos apenas na árvore conjunta de Controle e Queimada.

Como mencionado anteriormente, membros do Grupo I do filo Crenarchaeota estão sendo atualmente classificados por muitos autores como pertencentes ao filo Thaumarchaeota, proposto em 2008 por Brochier-Armanet e colaboradores, e tal classificação vem sendo cada vez mais aceita na literatura (Spang et al., 2010; Pester et al., 2011). Essa foi a classificação considerada neste trabalho e utilizada nas árvores filogenéticas. Isolados dos grupos I.1a e I.1b de Thaumarchaeota selecionados, juntamente com número de acesso de suas sequências, foram os seguintes: Cenarchaeum symbiosum (U51469.1), Nitrosopumilus maritimus (JQ346765.1), Candidatus Giganthauma insulaporcus (FN825808.1), Candidatus Giganthauma karukerense (FN398074.1), Candidatus Nitrosotalea devanaterra (JN227488.1) - Grupo I.1a de Thaumarchaeota; Candidatus Nitrososphaera gargensis (GU797786.1), Nitrososphaera viennensis (FR773157.1) - Grupo I.1b de Thaumarchaeota. Também foi incluído o único representante cultivado do Hot Water Crenarchaeotic Group III Candidatus Nitrosocaldus yellowstonii (EU239960.1) - considerado pelos mesmos autores já citados como do filo Thaumarchaeota.

Até o momento, nenhum organismo pertencente ao grupo I.1c de Thaumarchaeota foi cultivado em meios artificais. Como a maioria das sequências obtidas neste trabalho foram classificadas pelo Greengenes como pertencentes a esse grupo, sequências de organismos não cultivados deste grupo também foram incluídas na árvore, visando um melhor posicionamento filogenético das nossas sequências. Além disso, como ainda é pequeno o 
número de archaeas cultivadas, sequências de archaeas ainda não cultivadas depositadas no banco de dados do NCBI e consideradas próximas às encontradas neste trabalho de acordo com a ferramenta BLAST (Altschul et al., 1990) também foram incluídas nas árvores filogenéticas, objetivando-se uma melhor estimativa da classificação filogenética de nossas sequências.

Todas as árvores filogenéticas foram construídas pelo programa MEGA5 (Tamura et al., 2011) empregando-se o método de Neighbor-joining proposto por Saitou e Nei (1987), por ser o mais simples e ser comumente usado para a construção de árvores filogenéticas com o gene de rRNA 16S. Este método utiliza o princípio da evolução mínima, gerando uma matriz de distância entre as sequências e uma árvore filogenética única com os menores comprimentos (Saitou \& Nei, 1987). 


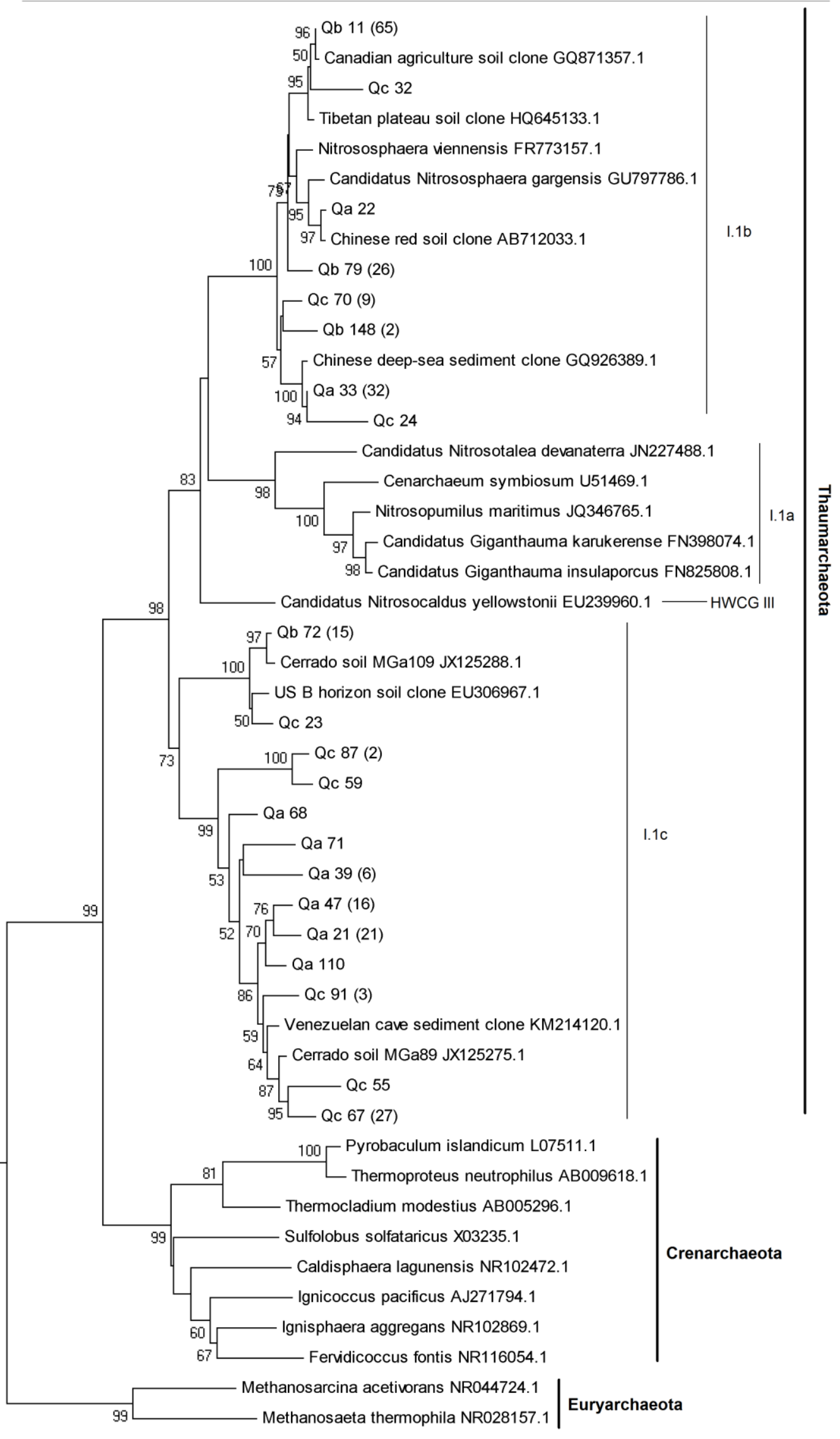

Uncultured Acidobacterium sp JQ825222.1

5.05 
Figura 18. Árvores filogenéticas com as sequências dos representantes de cada OTU (3\%) das réplicas de Controle $\mathrm{Ca}, \mathrm{Cb}$ e $\mathrm{Cc}(\mathrm{A})$ e das réplicas de Queimada $\mathrm{Qa}, \mathrm{Qb}$ e Qc (B) alinhadas com sequências de archaeas cultivadas e não cultivadas retiradas do banco de dados do NCBI. Os números de acesso encontram-se ao lado do nome de cada sequência Os valores indicados entre parênteses ao lado do nome de cada clone indicam o número de sequências representadas pela OTU. Clones que não têm valores indicados ao lado são singletons, OTUs representadas por uma única sequência. As árvores foram construídas pelo método Neighborjoining (Saitou \& Nei, 1987), com o modelo de Jukes-Cantor (Jukes \& Cantor, 1969) e teste de 1000 bootstrap (Felsenstein, 1985). Valores de bootstrap menores que 50 não são mostrados nas árvores. A barra de escala indica a distância da similaridade dos ramos. Uma sequência da bactéria Acidobacterium sp. foi utilizada como grupo externo em cada uma das árvores. Filos e grupos de archaea estão indicados. MCG: Miscellaneous Crenarchaeotic Group. HWCG III: Hot Water Crenarchaeotic Group III.

Ao alinharmos as 233 sequências das três réplicas de Controle, foram geradas 31 OTUs representativas a nível de espécie (3\%). Ao serem posicionadas na árvore filogenética (Figura 18A), as OTUs foram distribuídas no grupo I.1b (6 OTUs representando 49 sequências) e I.1c (24 OTUs representando 181 sequências) de Thaumarchaeota, além de 1 OTU representando 3 sequências posicionadas em um clado à parte. De acordo com a classificação realizada pelo Greengenes, essas três sequências representadas pelo clone Cb54 pertencem ao grupo Miscellaneous Crenarchaeotic Group (MCG).

O MCG, como já mencionado na seção 4.1.7.1, já foi identificado em diversos tipos de ambientes terrestres e aquáticos e ainda não possui nenhum representante cultivado (Kubo et al., 2012). Este grupo não apresenta uma afiliação clara com qualquer filo de Archaea e seu posicionamento é instável em árvores de rRNA 16S (Pester et al., 2011). Uma sequência identificada em turfeiras do sul da Mata Atlântica, previamente afiliada a este grupo pelos autores (número de acesso HQ614436.1, Etto et al., 2012), foi incluída na árvore e mostrou forte afiliação com Cb54. Por não apresentar qualquer representante cultivado, pouco se sabe sobre a fisiologia e ecologia destes organismos (Meng et al., 2014).

No caso das réplicas de Queimada (Figura 18B), foram geradas 22 OTUs a partir das 233 sequências, das quais 9 foram posicionadas no grupo I.1b (representando 137 sequências) e as 13 OTUs restantes (representando 96 sequências) foram posicionadas no grupo I.1c de Thaumarchaeota.

Como já mencionado, a prevalência de sequências afiliadas aos grupos I.1b e I.1c é condizente com a literatura, já que vários estudos descrevem esses dois grupos como sendo dominantes em ambientes terrestres (Ochsenreiter et al., 2003; Timonen \& Bomberg, 2009). O grupo I.1c de Thaumarchaeota ainda não apresenta qualquer representante cultivado 
descrito na literatura e, por esta razão, praticamente não há informações acerca das características dos organismos deste grupo. No entanto, membros deste grupo vêm sendo frequentemente associados a solos com $\mathrm{pH}$ mais ácido, como descrito em diversos trabalhos que empregaram metodologias independentes de cultivo (Jurgens et al., 1997; Kemnitz et al., 2007; Lehtorvita et al., 2009). Desta forma, a identificação de muitas sequências posicionadas neste grupo poderia estar relacionada ao $\mathrm{pH}$ mais ácido encontrado nos solos de Cerrado (Haridasan, 1994; Moreira, 2000; Araújo et al., 2012) - por volta de 5 de acordo com as medições feitas neste trabalho nos solos de ambas as condições analisadas (Tabela 4). Além disso, muitas sequências pertencentes a este grupo também foram identificadas no trabalho de Catão e colaboradores (2013) com solo de Cerrado Denso e Mata de Galeria, indicando que membros do grupo I.1c seriam comuns em diferentes fitofisionomias do Cerrado. Duas sequências obtidas pelos autores, e afiliadas ao grupo I.1c em árvores construídas em seu trabalho, foram incluídas nas árvores (clones MGa109 e MGa89, números de acesso JX125288.1 e JX125275.1) e ficaram proximamente associadas com sequências representativas de Controle (Ca143, Ca49 e Cc18, que ao todo representam 52 sequências) e Queimada (Qb72, Qc55, Qc67, que ao todo representam 43 sequências) (Figura 18).

O grupo I.1b de Thaumarchaetota foi identificado como sendo o grupo dominante de archaeas em diversos tipos de solos (Brintim et al., 1997; Auguet et al., 2010; Bates et al., 2011). Até o momento, são poucos os relatos que descrevem o cultivo de enriquecimento de organismos deste grupo (Simon et al., 2005; Kim et al., 2012, Xu et al., 2012) e a espécie Nitrososphaera viennensis, isolada de amostras de solo de um jardim em Viena, é a única a ter sido obtida na forma de culturas puras (Stieglmeier et al., 2014). Outra archaea deste grupo, a qual encontra-se melhor descrita, é Candidatus Nitrososphaera gargensis que, apesar de ainda não ter sido obtida na forma de cultura pura, já teve seu genoma completamente sequenciado (Spang et al., 2012) após uma cultura de enriquecimento obtida a partir de amostras de uma fonte termal terrestre (Hatzenpichler et al., 2008). Muitas sequências proximamente relacionadas a estes organismos já foram identificadas em diversos solos (Paster et al., 2012). Nas árvores filogenéticas apresentadas na Figura 18, algumas sequências representativas tanto de Controle quanto de Queimada foram afiliadas a essas archaeas, assim como algumas sequências de não cultivadas selecionadas do banco de dados e incluídas na árvore.

Todas as sequências pertencentes ao grupo I.1b foram classificadas com 100\% de identidade com o gênero Nitrososphaera, de acordo com o Greengenes. No entanto, ao se observar a árvore construída, várias OTUs formaram clados próprios, aproximando-se mais 
de sequências de archaeas não cultivadas. Alguns estudos vêm mostrando que sequências de rRNA 16S com identidade próxima a $100 \%$ podem ser encontradas em organismos com características fisiológicas bastante diferentes (Fox et al., 1992; Lehtorvita-Morley et al., 2014). Desta maneira, é possível que as sequências detectadas neste estudo pertençam a espécies do gênero Nitrososphaera ainda não cultivadas, ou ainda a outros gêneros similares, também pertencentes ao grupo I.1b.

Do ponto de vista ecológico, o filo Thaumarchaeota inclui organismos conhecidos por apresentarem o metabolismo nitrificante, podendo ter importante papel no ciclo do nitrogênio em diversos ambientes (Zhang et al., 2010; Pester et al., 2011; Kim et al., 2012; Xu et al., 2012). Dados obtidos após o sequenciamento do genoma completo de Candidatus Nitrososphaera gargensis (Spang et al., 2012) e Candidatus Nitrososphaera evergladensis (Zhalnina et al., 2014) e a obtenção e caracterização de Nitrososphaera viennensis em cultura pura (Tourna et al., 2011; Stieglmeier et al., 2014), permitiram elucidar alguns aspectos do metabolismo de oxidação de amônia nos organismos do grupo I.1b, revelando que estes organismos provavelmente apresentam importante papel ecológico no ciclo do nitrogênio em solos. Alguns membros do grupo I.1a de Thaumarchaeota também possuem a capacidade de oxidar amônia, e representantes cultivados com tal tipo de metabolismo foram isolados, em sua maioria, de ambientes marinhos (Preston et al., 1996; Könneke et al., 2005; Muller et al., 2010), havendo um representante isolado de solo agriculturável (Jung et al., 2011). Até o momento, não se conhece qualquer associação entre organismos do grupo I.1c e o metabolismo de oxidação de amônia.

No alinhamento entre as sequências de Controle e Queimada em conjunto foram obtidas 32 OTUs representativas a nível de espécie (3\%), das quais 12 eram singletons. Na árvore construída com estas sequências representativas (Figura 19), onde não foram adicionados os singletons, 6 OTUs (representando 183 sequências) foram posicionadas no grupo I.1b e 13 OTUs (representando 271 sequências) foram posicionadas no grupo I.1c, além da OTU representada por Cb54 que foi posicionada no MCG.

As árvores também indicaram uma associação entre sequências obtidas neste trabalho e sequências de archaeas não cultivadas identificadas em superfícies de rocha em uma caverna da Venezuela (KM214120.1, Barton et al., 2014), solo de uma pradaria no platô tibetano (número de acesso GQ127307.1, artigo ainda não publicado), solo ácido da China (FJ584387.1, Ying et al., 2010), horizonte B de solo dos Estados Unidos (EU306967.1, Hansel et al., 2008), solo de agricultura do platô tibetano (número de acesso HQ645133.1, artigo ainda não publicado) e solo de agricultura do Canadá (GQ871351.1, Chan et al., 2013), 
todas previamente afiliadas com os grupos I.1c ou I.1b de Thaumarchaeota. É interessante notar que as sequências de organismos próximas às sequências identificadas neste trabalho também foram, em sua maioria, detectadas em solos.

Alguns clados foram formados exclusivamente por sequências obtidas neste trabalho. Apesar de não ser possível afirmarmos que se tratam de sequências novas sem afiliação previamente descrita, pois para isso seria necessária a construção de uma árvore com todas as sequências de rRNA 16S disponíveis nos bancos de dados, a formação desses clados pode indicar que existam archaeas ainda não descritas nos solos de Cerrado sensu stricto.

Comparando-se com outras fitofisionomias de Cerrado analisadas quanto à diversidade de archaeas no trabalho de Catão e colaboradores (2013), nota-se uma similaridade entre os resultados encontrados no Cerrado sensu stricto típico analisado neste estudo e aqueles encontrados em Cerrado Denso, onde todas as sequências também foram afiliadas aos grupos I.1b e I.1c de Thaumarchaeota. Como já mencionado, diferenças encontradas na densidade do estrato arbóreo-arbustivo da vegetação do Cerrado sensu stricto levam a sua subdivisão em Cerrado sensu stricto típico, Cerrado Denso e Cerrado Ralo (Ribeiro \& Walter, 1998). Assim, os resultados encontrados neste estudo, quando comparados aos de Catão e colaboradores (2013), indicam que, apesar das diferenças relacionadas à densidade do estrato arbóreo-arbustivo da vegetação, a composição da comunidade de archaeas do solo sob áreas de Cerrado sensu stricto típico e Cerrado Denso é bastante similar. Já em Mata de Galeria foram também identificados organismos do grupo I.1a, comumente descritos em ambientes aquáticos, cuja presença nos solos desta fitofisionomia poderia ser explicada pelo alto conteúdo de água nos seus solos (Catão et al., 2013). 


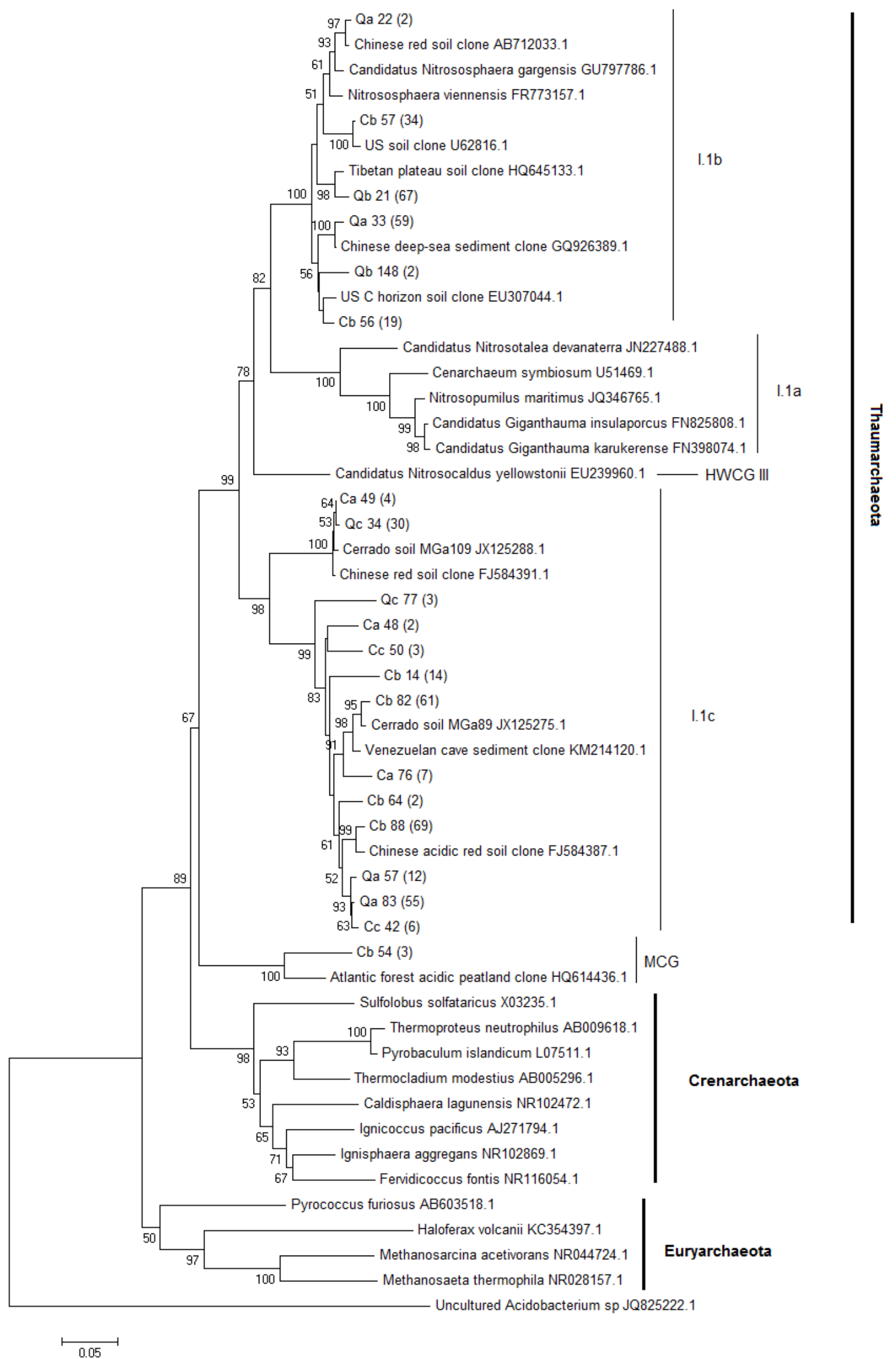


Figura 19. Árvore filogenética com as sequências do gene rRNA 16S dos representantes de cada OTU (3\%) de Controle e Queimada alinhadas com sequências de archaeas cultivadas e não cultivadas retiradas de banco de dados do NCBI. Os números de acesso estão mostrados ao lado do nome de cada sequência. Os valores indicados entre parênteses ao lado do nome de cada clone indicam o número de sequências representadas pela OTU. Os singletons não foram colocados na árvore. A árvore foi construída pelo método Neighbor-joining (Saitou \& Nei, 1987), com o modelo de Jukes-Cantor (Jukes \& Cantor, 1969) e teste de 1000 bootstrap (Felsenstein, 1985). Valores de bootstrap menores que 50 não são mostrados na árvore. A barra de escala indica a distância da similaridade dos ramos. Uma sequência de uma bactéria Acidobacterium sp. foi utilizada como grupo externo. Filos e grupos de archaea estão indicados. MCG: Miscellaneous Crenarchaeotic Group. HWCG III: Hot Water Crenarchaeotic Group III.

Outra questão interessante consistiu no fato de que apesar da grande maioria das sequências, tanto de Controle quanto de Queimada pertencerem o grupo I.1b e I.1c de Thaumarchaeota, houve uma distribuição heterogênea das sequências entre estes grupos. Nas réplicas de Controle houve uma predominância de sequências afiliadas ao grupo I.1c (Figura 18A), enquanto que nas réplicas de Queimada houve uma predominância de sequências afiliadas ao grupo I.1b (Figura 18B). Tal fato fica ainda mais evidente quando os dados são apresentados na forma de um histograma, com a porcentagem de sequências de cada uma das amostras obtidas em cada um dos grupos de Thaumarchaeota, como representado na Figura 20.

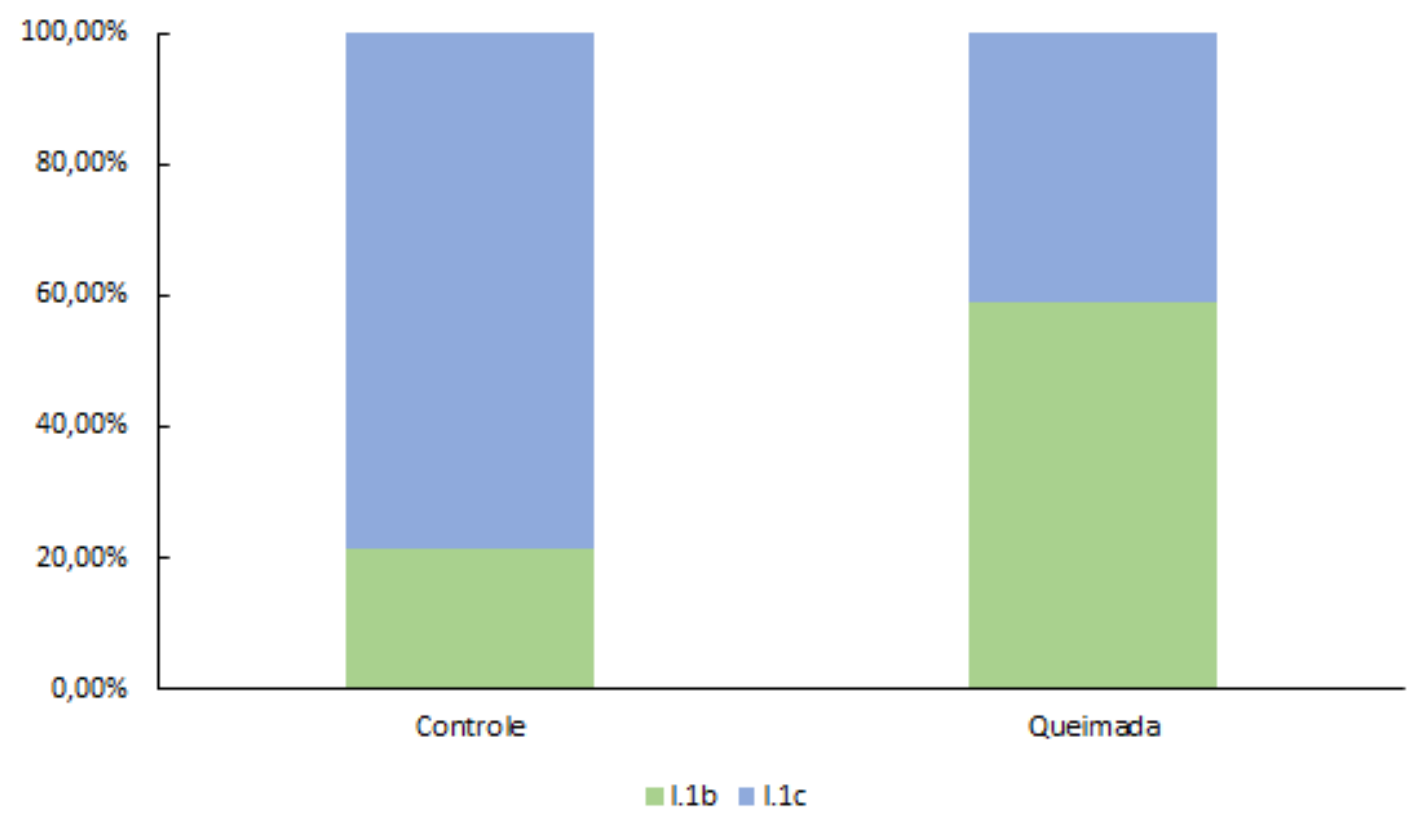

Figura 20. Histograma indicando a distribuição das sequências de Controle $(\mathrm{Ca}+\mathrm{Cb}+\mathrm{Cc})$ e Queimada (Qa+Qb+Qc) entre os grupos I.1b e I.1c de Thaumarchaeota. 
Como pode ser observado na Figura 20, cerca de $80 \%$ (78,7\%) das sequências de Controle encontravam-se afiliadas ao grupo I.1c, enquanto que aproximadamente $60 \%$ $(58,8 \%)$ das sequências de Queimada pertenciam ao grupo I.1b. Estes dados são coerentes com a hipótese de que as diferenças detectadas entre ambas as condições no PCoA (Figura 17) estariam relacionadas a uma diferença na abundância dos organismos entre Controle e Queimada.

Apesar da técnica de PCR empregada no trabalho não ser a mais adequada para constatar diferenças de abundância dos organismos entre as áreas, é notória a diferença de abundância de sequências entre os dois grupos. Uma vez que a mesma técnica foi empregada em ambas as condições, e pelo fato da PCR ser uma reação enzimática competitiva onde DNAs mais abundantes terão uma maior probabilidade de serem amplificados (Forney et al., 2004), é possível que os resultados obtidos reflitam uma diferença de abundância dos organismos destes grupos entre os solos de áreas de Cerrado que sofrem regime bienal de queima e aquelas que não sofrem.

No entanto, ao analisarmos as réplicas separadamente, poderíamos especular que esta diferença de abundância observada entre Controle e Queimada poderia estar sendo causada pelo grande número de sequências afiliadas ao grupo I.Ib detectadas especificamente na réplica Qb. A classificação das sequências pelo banco de dados Greengenes, indicou uma grande proporção das sequências desta réplica como pertencentes ao grupo I.1b (88 das 101 sequências), o que não foi observado nas demais réplicas de Queimada, que apresentaram mais sequências do grupo I.1c. Porém, é importante apontar que apesar de mais sequências de Qa e Qc terem sido agrupadas em I.1c, a diferença numérica em relação às sequencias de I.1b é menor do que a observada nas réplicas de Controle. A proporção expressiva de thaumarchaeotas do grupo I.1b em relação ao grupo I.1c em Qb poderia estar associada a alguma condição peculiar do solo neste ponto de coleta (proximidade com alguma raiz específica ou alguma atividade da fauna, por exemplo) que poderia estar favorecendo a maior abundância de membros do grupo I.1b apenas neste local específico. Assim, para se determinar se realmente há uma diferença de abundância entre organismos do grupo I.1b e I.1c nas áreas de Cerrado sensu stricto que poderia estar sendo causada pelas queimadas frequentes, mais pontos de coleta deveriam ser amostrados e as condições físico-químicas do solo em cada um deles devem ser aferidos.

Outra abordagem que poderia ser utilizada para se constatar se há uma diferença de abundância entre estes grupos nas duas condições analisadas são as técnicas de PCR em tempo real. Lehtorvita e colaboradores (2009) propuseram iniciadores específicos para o 
grupo I.1c e os utilizaram para estabelecer diferenças de abundância entre organismos deste grupo e outras archaeas em solos com $\mathrm{pH}$ diferentes. No entanto, como ressaltado pelos próprios autores, ainda há muitas dificuldades no desenvolvimento de iniciadores para grupos pouco conhecidos e muitos vieses podem ser adicionados nestas estimativas de abundância. Desta forma, espera-se que o crescente conhecimento acerca dos diferentes grupos de Archaea de solo permitam o desenvolvimento de novas ferramentas que resultem em uma melhor elucidação da composição da comunidade de Archaea em diferentes ambientes e/ou condições.

\subsubsection{Análises de sequências do gene $a m o A$}

Como já mencionado anteriormente, um número considerável de sequências de rRNA $16 \mathrm{~S}$ obtidas neste trabalho foram afiliadas a um grupo de Thaumarchaeta conhecidamente relacionado com o potencial de oxidação de amônia e acredita-se que organismos deste grupo tenham importante papel no ciclo do nitrogênio nos solos (Spang et al., 2010; Zhang et al., 2010; Bartossek et al., 2012).

A oxidação de amônia é realizada por organismos do domínio Bacteria e Archaea e ambos os domínios contém enzimas amônia-monoxigenases homólogas e consequentemente portam genes amo em seus genomas. O gene amoA codifica a subunidade alfa da enzima amônia-monoxigenase, pertencente à família de enzimas monoxigenages ligadas à membrana que contém cobre e esse gene é frequentemente utilizado como marcador filogenético e funcional em diversos estudos que visam a caracterização e quantificação de archaeas oxidantes de amônia no solo (Pester et al., 2012).

As 251 sequências do gene $a m o A$ (que preencheram os critérios de qualidade já mencionados no item 4.1.6) foram alinhadas pelo programa ClustalX de duas formas: 1) alinhamento múltiplo das sequências de cada réplica separadamente e 2) alinhamento múltiplo das sequências de todas as réplicas, de ambas as amostras analisadas $(\mathrm{amoCa}+\mathrm{Cb}+\mathrm{Cc}+\mathrm{amoQa}+\mathrm{Qb}+\mathrm{Qc})$.

Em seguida, os alinhamentos obtidos para cada uma das réplicas foram submetidos a análises, por meio do programa Mothur, para a determinação do número de OTUs observadas (Sobs) e a cobertura obtida para cada amostra (Tabela 12). Foi utilizado um coeficiente de dissimilaridade de $3 \%$ para esse gene, conforme adotado por outros autores (Prosser \& Nicol, 2008; Pester et al., 2012; Wu \& Conrad, 2014). 
Tabela 12. Número de OTUs observadas (Sobs) e cobertura obtida em cada réplica de Controle e Queimada para o gene amoA.

\begin{tabular}{ccccc}
\hline Amostra & Dissimilaridade & No Sequências & OTUs & Cobertura \\
\hline amoCa & $3 \%$ & 44 & 2 & $97,72 \%$ \\
amoCb & $3 \%$ & 45 & 2 & $100,00 \%$ \\
amoCc & $3 \%$ & 39 & 2 & $100,00 \%$ \\
\hline amoQa & $3 \%$ & 47 & 6 & $93,60 \%$ \\
amoQb & $3 \%$ & 46 & 2 & $100,00 \%$ \\
amoQc & $3 \%$ & 30 & 5 & $93,30 \%$ \\
\hline
\end{tabular}

Como pode ser observado na Tabela 12, utilizando-se um coeficiente de dissimilaridade de $3 \%$, poucas OTUs relativas ao gene amoA foram detectadas em cada uma das réplicas e uma cobertura superior a $90 \%$ foi alcançada em todas, sendo que em amoCb, amoCc e amoQb a cobertura foi de $100 \%$.

É curioso notar que nas réplicas amoQa e amoQc foi observado um número de OTUs maior que nas réplicas de Controle e na réplica amoQb. Tal resultado chama a atenção, já que a réplica $\mathrm{Qb}$ apresentou uma grande proporção de sequências de rRNA $16 \mathrm{~S}$ classificadas como do grupo I.1b, um grupo amplamente associado à oxidação de amônia. No entanto, esta foi a réplica de Queimada que apresentou o menor número de OTUs de amoA observadas. Esses dados são coerentes com o observado nas análises de alfa diversidade feitas com o gene do rRNA 16S (Tabela 10), onde a réplica Qb apresentou uma menor riqueza e diversidade em relação às outras duas réplicas de Queimada. Apesar de em Qb haver um expressivo número de sequências associadas ao grupo I.1b de Thaumarchaeota, é possível que essas sequências estejam agrupadas em um baixo número de OTUs, levando a uma baixa riqueza de espécies neste grupo. Assim, o menor número de OTUs observadas para o gene amoA em Qb é coerente com a baixa riqueza estimada para esta réplica nas análises de rRNA 16S.

Considerando-se o pequeno número de OTUs estimadas para o gene amoA com nível 3\% de dissimilaridade, foi construída apenas uma árvore filogenética com as sequências das réplicas de ambas as condições (Controle e Queimada). Tal árvore foi construída a partir de um alinhamento múltiplo entre as sequências representativas do gene amoA obtidas para Controle e Queimada e sequências do gene $a m o A$ de isolados cultivados e de archaeas não cultivadas obtidas no banco de dados do NCBI (Figura 21). A árvore foi construída pelos mesmos métodos utilizados para as árvores do gene rRNA 16S, ou seja, através do programa MEGA5 e com o método de Neighbor-joining.

Como pode-se observar na árvore, poucas sequências de amoA obtidas em nosso trabalho posicionaram-se no clado formado pelas sequências de amo $A$ dos organismos 
cultivados Nitrososphaera viennensis e Candidatus Nitrososphaera gargensis, pertencentes ao grupo I.1b (apenas 7 sequências, representadas por amoQc19 e amoQb23). Tal resultado é interessante, pois na árvore construída com sequências do gene do rRNA 16S houve muitas sequências afiliadas no mesmo clado destes organismos.

Além disso, na árvore de $a m o A$ uma sequência foi fortemente afiliada à sequência de amoA do organismo Canditatus Nitrosotalea devanaterra, associada ao grupo I.1a. Este organismo foi inicialmente isolado de solos de agricultura ácidos e foi relatado como sendo uma oxidante de amônia acidófila obrigatória (Lehtorvira-Morley et al., 2011). É curioso notar que na árvore construída para sequências de $16 \mathrm{~S}$, nenhuma sequência dentre todas as amostras apresentou afiliação com este organismo, ou mesmo um posicionamento próximo ao grupo I.1a de Thaumarchaeota.

Esses resultados obtidos nas árvores filogenéticas ressaltam a importância da utilização de mais de um gene na descrição de grupos microbianos específicos em ambientes naturais (Brochier-Armanet et al., 2008), pois revela a existência de diferenças quanto aos grupos filogenéticos obtidos com genes alvo diferentes.

Outro ponto importante a ser discutido é o fato da grande maioria das sequências de $a m o A$ terem sido posicionadas em um clado que possui apenas sequências de organismos não cultivados, inclusive uma OTU altamente representativa (amoQb40, representada por 188 das 251 sequências), fazendo com que essas sequências não possam ser associadas a qualquer grupo já descrito de archaeas oxidantes de amônia. É importante ressaltar ainda que a grande maioria das sequências de não cultivados do banco de dados NCBI que apresentaram alta similaridade com as sequências obtidas neste estudo foram identificadas também em solos.

$\mathrm{O}$ fato da grande maioria das sequências de $a m o A$ obtidas não terem sido afiliadas em clados contendo organismos cultivados em meios artificiais indica a possibilidade da existência de organismos oxidantes de amônia ainda não descritos nos solos de Cerrado sensu stricto. Outro resultado que reforça esta ideia se encontra nas análises das sequências de rRNA 16 S afiliadas ao grupo I.1b, das quais muitas foram posicionadas em clados diferentes daquele formado pelas Nitrososphaera já descritas. 


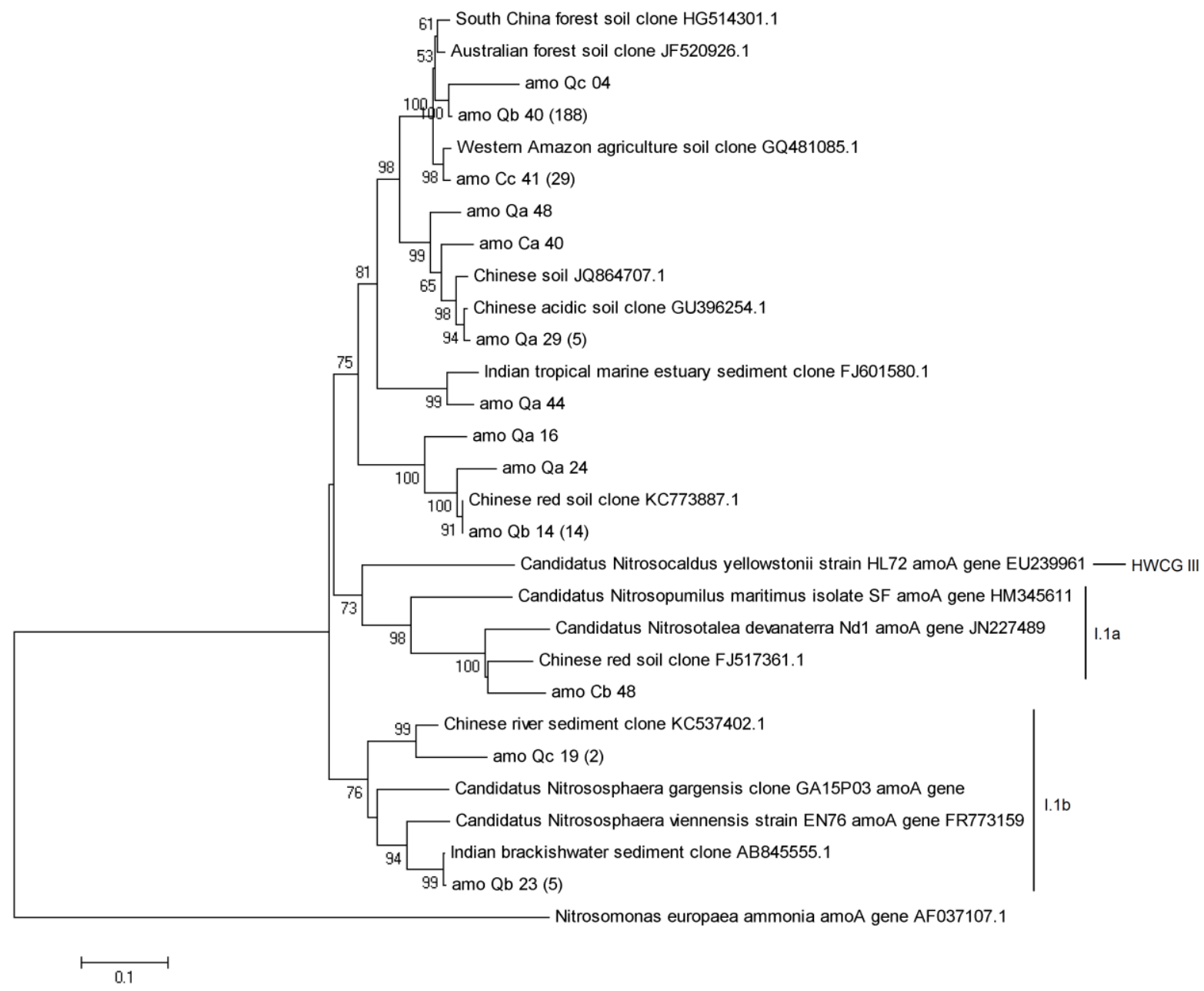

Figura 21. Árvore filogenética com as sequências de amoA representantes de cada OTU (3\%) de Controle e Queimada alinhadas com sequências de $a m o A$ de archaeas cultivadas e não cultivadas retiradas de banco de dados do NCBI. Os números de acesso estão mostrados ao lado do nome de cada sequência. Os valores indicados entre parênteses ao lado do nome de cada clone indicam o número de sequências representada pela OTU. Clones que não têm valores indicados ao lado são singletons, OTUs representadas por uma única sequência. A árvore foi construída pelo método Neighbor-joining (Saitou \& Nei, 1987), com o modelo de Jukes-Cantor (Jukes \& Cantor, 1969) e teste de 1000 bootstrap (Felsenstein, 1985). Valores de bootstrap menores que 50 não são mostrados na árvore. A barra de escala indica a distância da similaridade dos ramos. Uma sequência de amoA da bactéria Nitrosomonas europea foi utilizada como grupo externo. Os grupos de Thaumarchaeota I.1a, I.1b e Hot Water Crenarchaeotic Group III (HWCG III) estão indicados. 


\subsection{Obtenção de culturas de Archaea em meios artificiais}

Para a confecção de meios de cultura e o estabelecimento de um cultivo de archaeas, solo de Cerrado sensu stricto foi coletado em 02 de setembro de 2013, em uma área não submetida a queimadas há vários anos (área Controle). Levando em consideração nossa experiência prévia com o cultivo de archaeas provenientes de solo de jardim, vários antibióticos foram adicionados ao meio de cultivo desde o primeiro inóculo, visando a obtenção de uma cultura pura de archaeas, sem a presença de bactérias. Assim, foram adicionados ao meio os seguintes antibióticos, de forma conjunta: ampicilina, estreptomicina, bacitracina, cloranfenicol, norfloxacina, doxiciclina, itraconazol, cetoconazol e anfotericina B. No entanto, tal abordagem mostrou-se inadequada, já que não foi possível observar crescimento nas placas de cultivo após vários dias e até mesmo meses. Tal resultado pode ter sido decorrente do grande número de antibióticos utilizados desde o primeiro inóculo. Uma vez que tais agentes antimicrobianos apresentam uma grande diversidade de alvos moleculares, sua adição conjunta pode ter interferido no metabolismo e crescimento das archaeas, impedindo seu desenvolvimento. De acordo com a literatura, apesar das grandes diferenças estruturais e fisiólogicas das archaeas, quando comparadas às bactérias, já foi descrita a atividade antimicrobiana de alguns antibióticos sobre alguns grupos de organismos pertencentes ao domínio Archaea (Dridi, 2012; Khelaifia \& Drancourt, 2012). Outra possibilidade que poderia explicar a completa ausência de crescimento microbiano nos meios de cultura seria decorrente da eliminação de bactérias essenciais ao crescimento in vitro das archaeas, devido ao grande número de antibióticos utilizados conjuntamente. Estudos envolvendo o cultivo de archaeas de solo têm mostrado que ao se eliminar as bactérias de cocultivos entre archaea e bactérias, as archaeas também desaparecem, indicando uma possível dependência entre estes organismos para seu crescimento (Lehtovirta-Morley et al., 2014). Desta forma, no intuito de dar continuidade ao trabalho de cultivo de archaeas de solo de cerrado em meios artificiais, uma nova coleta de solo foi realizada na mesma área de Cerrado sensu stricto em 29 de janeiro de 2014.

\subsubsection{Coleta dos solos e análises dos seus parâmetros físico-químicos}

O solo coletado em janeiro de 2014, na área controle (protegida do fogo há muitos anos), foi utilizado para a confecção dos meios de cultura e serviu como inóculo inicial, visando o estabelecimento de um cultivo de archaeas provenientes de solo de Cerrado. Esse 
solo, que foi coletado na estação chuvosa, teve suas características físico-químicas analisadas pela empresa SOLOQUÍMICA Análise de solos LTDA. Os resultados da análise podem ser vistos na Tabela 13.

Tabela 13. Valores dos parâmetros físico-químicos do solo de Cerrado sensu stricto coletado na área Controle, para o estabelecimento do cultivo.

\begin{tabular}{cc}
\hline Parâmetros analisados & Cerrado Controle - Cultivo \\
\hline $\mathrm{pH}$ & 4,70 \\
Fósforo $(\mathrm{ppm})$ & 0,80 \\
Cálcio $\left(\mathrm{cmol}_{\mathrm{c}} / \mathrm{dm}^{3}\right)$ & 0,30 \\
Magnésio $\left(\mathrm{cmol}_{\mathrm{c}} / \mathrm{dm}^{3}\right)$ & 0,10 \\
Potássio $\left(\mathrm{cmol}_{\mathrm{c}} / \mathrm{dm}^{3}\right)$ & 0,09 \\
Sódio $\left(\mathrm{cmol}_{\mathrm{c}} / \mathrm{dm}^{3}\right)$ & 0,04 \\
Alumínio $\left(\mathrm{cmol}_{\mathrm{c}} / \mathrm{dm}^{3}\right)$ & 1,00 \\
Carbono Orgânico $(\mathrm{g} / \mathrm{kg})$ & 58,4 \\
Nitrogênio total $(\mathrm{g} / \mathrm{kg})$ & 0,61 \\
Nitrogênio nitrato & 0,15 \\
Nitrogênio nitrito & 0,15 \\
Nitrogênio amoniacal & 0,05 \\
Matéria orgânica $(\mathrm{g} / \mathrm{kg})$ & 100,4 \\
Boro $(\mathrm{ppm})$ & 0,83 \\
Cobre $(\mathrm{ppm})$ & 0,85 \\
Ferro $(\mathrm{ppm})$ & 287 \\
Manganês $(\mathrm{ppm})$ & 3,20 \\
Zinco $(\mathrm{ppm})$ & 0,43 \\
Enxofre $(\mathrm{ppm})$ & 5,20 \\
\hline
\end{tabular}

\subsubsection{Obtenção de culturas de Archaea em meios artificiais}

Para o estabelecimento de cultivos de archaeas de ambientes mesófilos, meios de cultura foram confeccionados a partir do mesmo solo do qual foi retirado o inóculo inicial. Essa metodologia de confecção de meios visava uma maior proximidade entre os componentes do meio natural dos microrganismos presentes no inóculo e os do meio artificial de cultivo laboratorial. Nos últimos anos, vários artigos têm ressaltado a importância do emprego de condições de cultivo mais próximas àquelas encontradas na natureza. Tais trabalhos defendem que o grande número de microrganismos que não puderam ser cultivados em laboratório até hoje é devido ao distanciamento entre as condições encontradas nos seus ambientes naturais e aquelas que são utilizadas nos meios de cultivo tradicionais e propõem formas para diminui-lo (Kaeberlein, et al., 2002; Zengler, et al., 2002, Aoi, et al., 2009). Com base nesse conceito, formulamos um meio de cultura a partir de um coado do solo misturado 
à água destilada, disponibilizando assim um meio para o crescimento dos microrganismos que fosse nutricionalmente próximo ao solo do cerrado.

Por apresentarem diferenças metabólicas e estruturais em relação às bactérias, as archaeas são resistentes a vários tipos de antibióticos rotineiramente utilizados (Dridi, et al., 2011; Khelaifia e Drancourt, 2012). Desta forma, visando a eliminação de bactérias e fungos e um enriquecimento de archaeas no cultivo, antibióticos (ampicilina, estreptomicina, cloranfenicol) e antifúngicos (itraconazol e cetoconazol) com diferentes alvos moleculares, foram adicionados sucessivamente ao meio de cultura. Após alguns repiques, a contaminação por fungos foi eliminada e colônias bastante diminutas, com aspecto de crescimento procariótico, puderam ser observadas nas placas.

Após cerca de quatro repiques sucessivos dos organismos cultivados, realizados com uma frequência aproximada de 1 mês entre cada um, foi possível a identificação de cinco morfologias coloniais distintas, que receberam as denominações 1 a 5 . O tipo colonial 1, com diâmetro de cerca de $1 \mathrm{~mm}$ após um mês de cultivo, apresentava morfologia arredondada, com aspecto brilhante, exibindo uma pequena região central arredondada e opaca, e a região externa menos densa, assemelhando-se a um "ovo frito" (Figura 22A). O tipo colonial 2, com diâmetro de aproximadamente $0,5 \mathrm{~cm}$, apresentava bordas irregulares, com aspecto rendado e uma região central protuberante, mais densa, com forma arredondada (Figura 22B). Este tipo colonial era facilmente removido do meio de cultura. O tipo colonial 3, com diâmetro médio de cerca de 0,5 cm, apresentava aspecto opaco, com bordos irregulares e mostrava-se bastante aderente ao meio de cultivo (Figura 22C). O tipo colonial 4, também com diâmetro médio de 0,5 cm, se assemelhava bastante ao tipo 3, no entanto apresentava aspecto mais translúcido e não se mostrava tão aderido ao meio de cultura (Figura 22D). O tipo colonial 5 consistia em colônias extremamente pequenas, com menos de $1 \mathrm{~mm}$ de diâmetro após mais de 1 mês de cultivo, com aspecto brilhante e arredondado (Figura 22E). Curiosamente, dependendo do tempo de incubação das culturas, muitas vezes o tipo colonial 2 apresentava um aspecto brilhante e mucilaginoso, o qual era perdido com o decorrer do tempo de incubação (Figura 22F). 

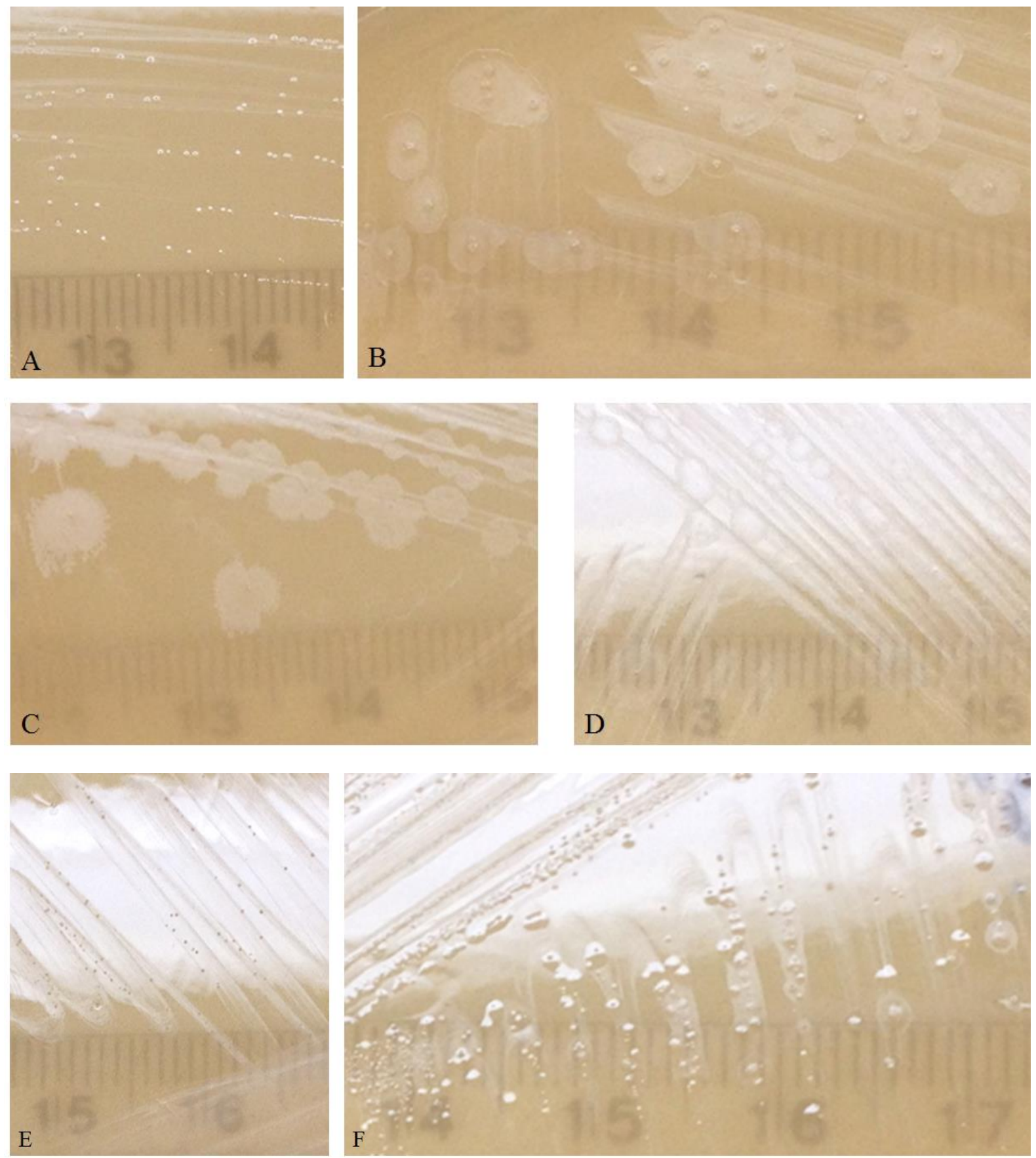

Figura 22. Tipos coloniais obtidos em meios de cultura inoculados com o solo de cerrado. ATipo de colônia 1. B - Tipo de colônia 2. C- Tipo de colônia 3. D- Tipo de colônia 4. E Tipo de colônia 5. F - Variação que ocorre na colônia 2 em determinados momentos do cultivo, onde as colônias apresentam aspecto mais mucilaginoso.

Outros tipos coloniais também apresentavam aspectos morfológicos variáveis ao longo do tempo de cultivo. Por exemplo, a colônia 1, em determinados momentos após os repiques, também apresentava aspecto mais mucilaginoso. Tais alterações poderiam ser explicadas por alterações fisiólogicas das células, tais como a produção de matriz extracelular, pois análises microscópicas destas amostras, coradas pela metodologia de Gram, sugeriram a 
presença de um envoltório extracelular frouxo, de espessura variável, em algumas amostras (Figuras 24 e 25). Outra característica observada foi o crescimento mais acelerado das culturas, após vários repiques. Inicialmente, as colônias apresentavam um crescimento que possibilitava o repique a cada mês. Após aproximadamente 8 meses de repiques sucessivos, no entanto, as placas passaram a apresentar um crescimento mais acelerado, sendo possível a realização de repiques em menores intervalos, como a cada 10 dias. Tal fato poderia ser explicado por uma melhor adaptação dos microrganismos ao meio de cultivo artificial, o que teria aumentado sua taxa de crescimento.

Uma questão que deve ser ainda esclarecida e solucionada consiste na impossibilidade do estabelecimento destas culturas em meios líquidos. O inóculo inicial foi semeado tanto em placas de cultivo com meio sólido, quanto em tubos contendo meio líquido. Ambos os meios foram preparados da mesma forma (a partir de um coado do solo misturado à água destilada), sendo a única diferença o procedimento de esterilização do meio que, no caso dos meios sólidos foi realizado em autoclave, enquanto o meio líquido foi submetido à filtração em membranas de $0,22 \mu \mathrm{m}$. Tanto as placas com meio sólido quanto os tubos com meio líquido foram suplementados com os agentes antimicrobianos já citados e incubados em estufa a $28^{\circ} \mathrm{C}$. Após algumas semanas foi possível a observação de colônias no meio sólido, mas não foi observado qualquer indício de crescimento nos meios líquidos. Tubos contendo inóculos em meio líquido também foram incubados sob agitação de $150 \mathrm{rpm}$ a $28^{\circ} \mathrm{C}$, mas também não foi observado qualquer indício de crescimento microbiano nessas condições. Mesmo sem a evidência de crescimento nos meios líquidos, alíquotas destes foram inoculadas em placas com meio sólido, mas também não foi observada a formação de colônias após várias semanas.

A ausência de crescimento em meios líquidos poderia ser explicada pela necessidade de adesão dos microrganismos a um suporte sólido, impossibilitando seu crescimento em suspensão. No entanto, tal hipótese não explicaria o não crescimento dos microrganismos em tubos incubados na estufa, sem qualquer agitação.

A ausência de crescimento em meios líquidos impossibilitou a realização de uma série de análises fisiológicas destes organismos, tais como confecção de uma curva de crescimento, para o estabelecimento do tempo de geração das diferentes culturas, bem como análises que permitissem inferir as condições ótimas de temperatura, $\mathrm{pH}$, ou resposta dos microrganismos a diferentes tipos de nutrientes adicionados aos meios.

Tal fato mostra-se bastante curioso, tendo em vista que dentre as poucas archaeas mesófilas de solo não anaeróbias cultivadas até o momento, todas foram cultivadas com 
sucesso em meios líquidos (Simon et al., 2005; Kim et al., 2012; Xu et al., 2012; Stieglmeier et al., 2014; Zhalnina et al., 2014).

O sequenciamento de DNA dos produtos de PCR para o gene do rRNA $16 \mathrm{~S}$ da colônia 2 revelaram a ocorrência de um co-cultivo entre archaeas e bactérias (resultados apresentados e discutidos nos itens 4.2.4 a 4.2.6, adiante) e, por esta razão, os antibióticos bacitracina e norfloxacina foram adicionados aos meios de cultura, visando a eliminação da população bacteriana desta cultura. Após aproximadamente 10 dias de incubação, foi observada uma alteração do aspecto macroscópico das colônias nas placas adicionadas destes dois novos antibióticos. Como já descrito, o tipo colonial 2 nos meios contendo apenas ampicilina, estreptomicina e cloranfenicol apresentava bordas irregulares, com aspecto rendado e uma região central protuberante, mais densa, com forma arredondada. Após a adição da bacitracina e norfloxacina, as colônias passaram a apresentar três diferentes morfologias que passaram a ser denominadas $2 \mathrm{~A}, 2 \mathrm{~B}$ e $2 \mathrm{C}$. $\mathrm{O}$ tipo colonial $2 \mathrm{~A}$ apresentava um aspecto muito mucilaginoso com pontos centrais bastante protuberantes e tamanho de aproximadamente $0,5 \mathrm{~cm}$ (Figuras 23A e 23B). O tipo colonial 2B, com cerca de $1 \mathrm{~mm}$, apresentava aspecto arredondado, com a região central levemente aprofundada e aspecto menos mucilaginoso (Figura 23B). Já o tipo colonial 2C consistia em colônias pequenas, com tamanho inferior a 1mm, com morfologia arredondada e aspecto brilhante (Figura 23C). 


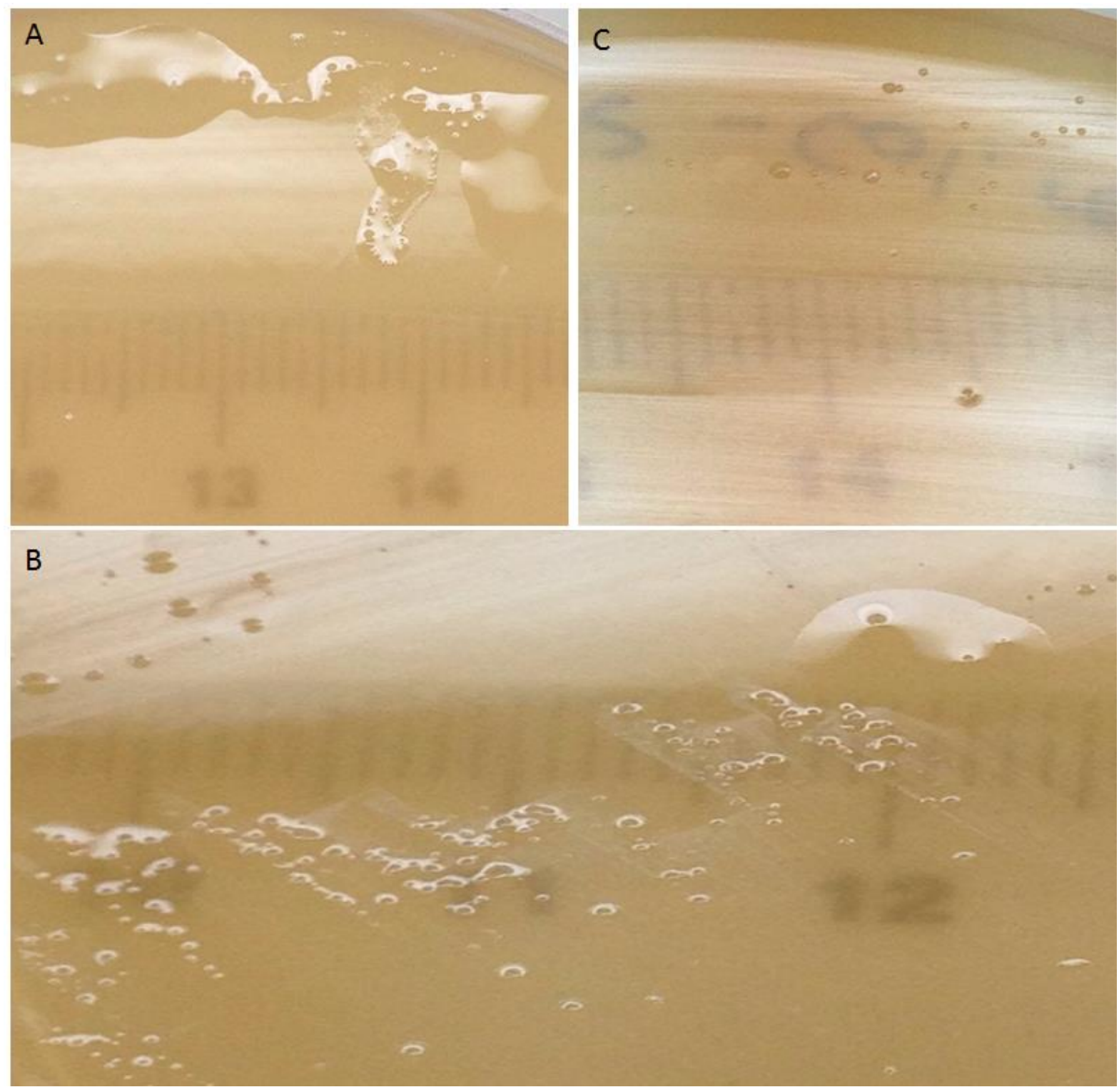

Figura 23. Tipos coloniais obtidos após o repique do tipo colonial 2 em meio de cultura com bacitracina e norfloxacina. A- Tipo colonial 2A. B - Tipos coloniais 2A e 2B. C- Tipo colonial $2 \mathrm{C}$.

\subsubsection{Coloração de Gram e visualização das células do cultivo por microscopia de luz}

As células dos diferentes tipos coloniais obtidos foram submetidas à coloração de Gram e visualizadas em microscópio óptico. Os esfregaços preparados a partir dos tipos coloniais desenvolvidos nos meios suplementados com ampicilina, estreptomicina e cloranfenicol são apresentados na Figura 24, enquanto a Figura 25 ilustra os esfregaços preparados a partir dos três tipos coloniais observados o crescimento do tipo colonial $2 \mathrm{em}$ meio de cultura adicionado de bacitracina e norfloxacina, além dos antibióticos que já vinham sendo utilizados anteriormente (ampicilina, estreptomicina e cloranfenicol). 

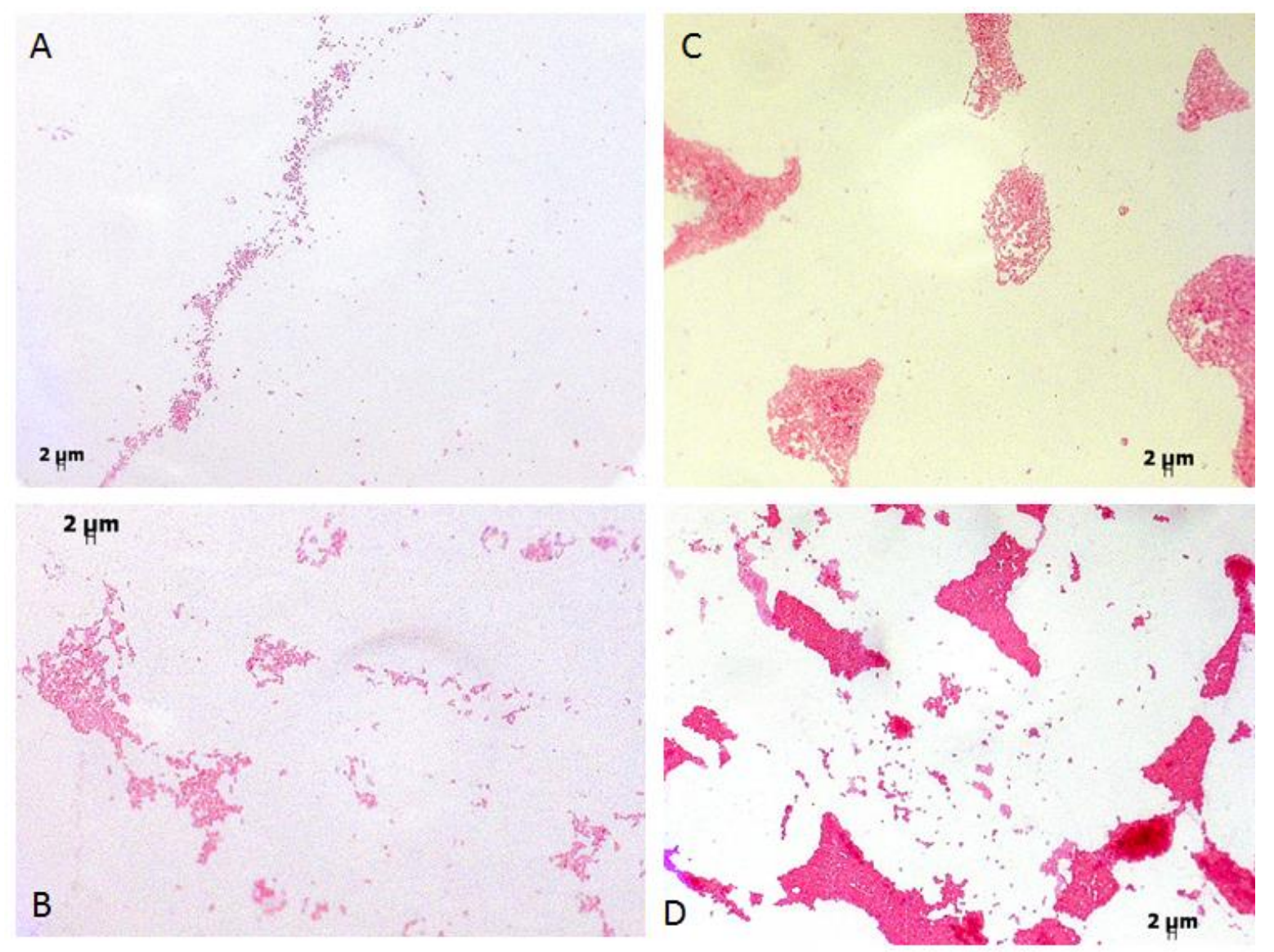

Figura 24. Coloração de Gram dos diferentes tipos coloniais obtidos. A- Células do tipo colonial 1. B- Células do tipo colonial 2. C-Células do tipo colonial 3. D- Células do tipo colonial 2, quando as colônias apresentavam aspecto mais mucilaginoso. Aumento 630X.

Pode-se observar que nos esfregaços preparados a partir das colônias do tipo 1, 2 e 3 (Figura 24) há uma predominância de células Gram negativas, com dimensões muito pequenas, com contornos de difícil visualização por microscopia óptica. Por estarem formando agregados celulares e por apresentarem dimensões tão diminutas, é difícil determinar por esta técnica se há mais de um tipo celular nos diferentes tipos coloniais analisados.

A coloração de Gram é amplamente utilizada para a caracterização inicial e diferenciação de organismos do domínio Bacteria, por possibilitar sua divisão de acordo com as duas estruturas de parede celular existentes neste domínio. No entanto, as archaeas apresentam paredes celulares com estrutura e composição muito variáveis, sendo muito diferentes daquelas encontradas em bactérias (Albers \& Meyer, 2011). Desta forma, pouco se sabe sobre o padrão de coloração apresentado pelas archaeas com diferentes tipos de parede celular submetidas à coloração de Gram. De acordo com 
Beveridge e Schultze-Lam (1996), archaeas que possuem camada S como único envoltório celular e/ou paredes celulares compostas por metanocondroitina coram-se como Gram negativas e apenas a archaea Methanobacterium formicicum, que possui a parede composta por pseudopeptideoglicano, apresenta o padrão de coloração Gram positivo. Estes autores sugeriram que o pseudopeptideoglicano, por ser uma molécula análoga ao peptideoglicano encontrado em bactérias, formaria uma estrutura de parede resistente, capaz de reter o cristal de violeta durante a coloração.
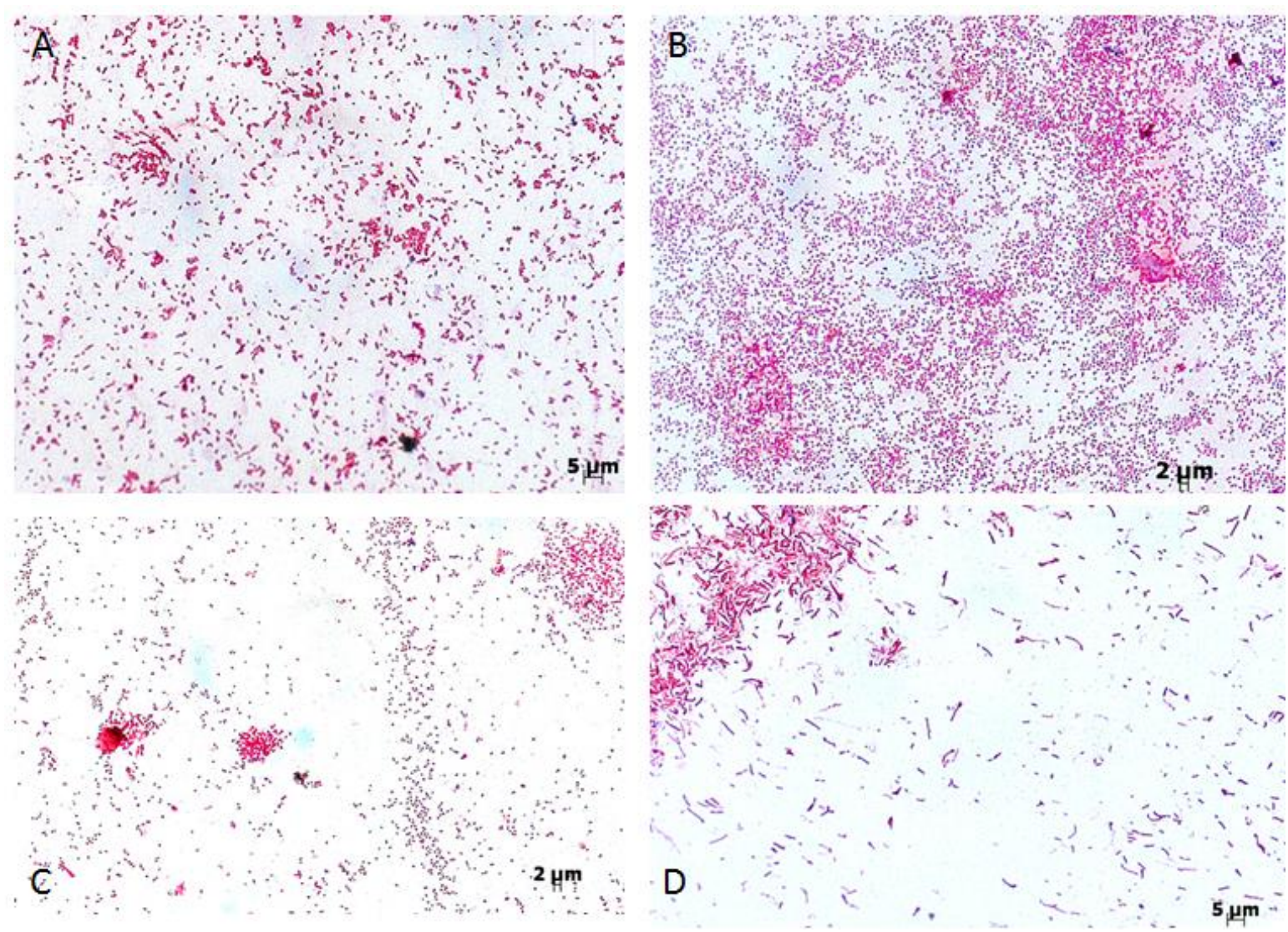

Figura 25. Coloração de Gram das células do tipo colonial 2 após crescimento em meio adicionado de bacitracina e norfloxacina. A e B-Células do tipo colonial 2A. C - Células do tipo colonial 2B. D- Célula do tipo colonial 2C. Aumento 630X.

Nas Figuras 25A, 25B e 25C, referentes aos tipos coloniais 2A e 2B, novamente pode ser verificada a predominância de células Gram negativas, de dimensões muito pequenas. No entanto, principalmente nas imagens das Figuras 25A e 25C, células maiores, com morfologia bacilar, podem ser identificadas entre as células menores. Já na Figura $25 \mathrm{D}$, referente ao tipo colonial $2 \mathrm{C}$, verifica-se a predominância de bacilos Gram negativos maiores, quando comparados às células presentes nas demais imagens. 


\subsubsection{Visualização por Microscopia Eletrônica de Varredura (MEV)}

Como será apresentado e discutido em itens à frente, a partir do DNA extraído do tipo colonial 2, foi possível a amplificação por PCR e posterior sequenciamento dos genes do rRNA 16S do domínio Archaea e Bacteria, indicando a ocorrência de um co-cultivo neste tipo colonial. Assim, o tipo colonial 2 foi repicado para meio adicionado dos antibióticos norfloxacina e bacitracina e os diferentes tipos coloniais obtidos após esta passagem (Figura 23) foram submetidos a análises por microscopia eletrônica de varredura (MEV). Células dos tipos coloniais $2 \mathrm{~A}$ e $2 \mathrm{~B}$ foram preparadas e analisadas por MEV e as imagens obtidas estão apresentadas nas Figuras 26 e 27. Amostras do tipo colonial 2C não foram preparadas para visualização por MEV devido à pequena quantidade de material disponível até o momento das análises, já que foram obtidas poucas colônias deste tipo.

Nas visualizações de ambos os tipos coloniais (2A e 2B) por microscopia eletrônica de varredura foi possível observar dois tipos celulares distintos: bacilos maiores, de 1 a $3 \mu \mathrm{m}$, e células cocoides, com aspecto irregular e diâmetro inferior a $1 \mu \mathrm{m}$ (Figuras 26 e 27). De acordo com descrições da literatura para as bactérias do gênero Novosphingobium (Takeuchi et al., 2001; Saxena et al., 2013), gênero ao qual foi afiliada a sequência de rRNA 16S de Bacteria amplificada a partir do cultivo com tipo colonial 2 (discutido abaixo, no item 4.2.7), é provável que os bacilos sejam as bactérias presentes no cultivo, enquanto as archaeas sejam as células menores, mais esféricas e irregulares.

Também foi possível a observação de aglomerados celulares com a presença de células cocoides e bacilos (Figuras 26C e 27A). Além disso, projeções celulares finas foram observadas entre as células (Figuras 27A e 27D), provavelmente envolvidas em processos de adesão célula-célula e/ou adesão entre as células e o substrato. 


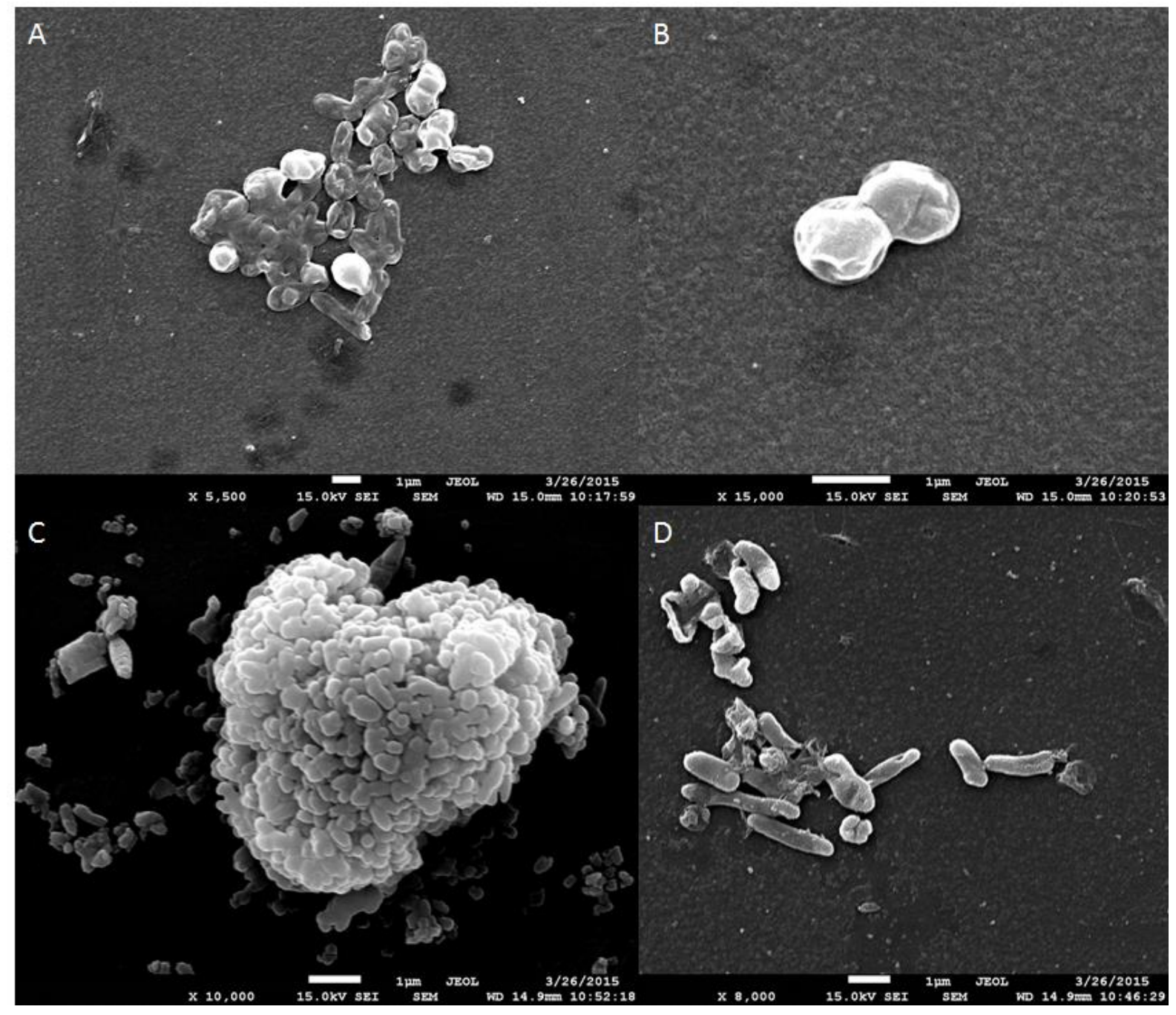

Figura 26. Células do tipo colonial $2 \mathrm{~A}$ observadas por microscopia eletrônica de varredura. Os aumentos utilizados estão indicados abaixo de cada imagem. 


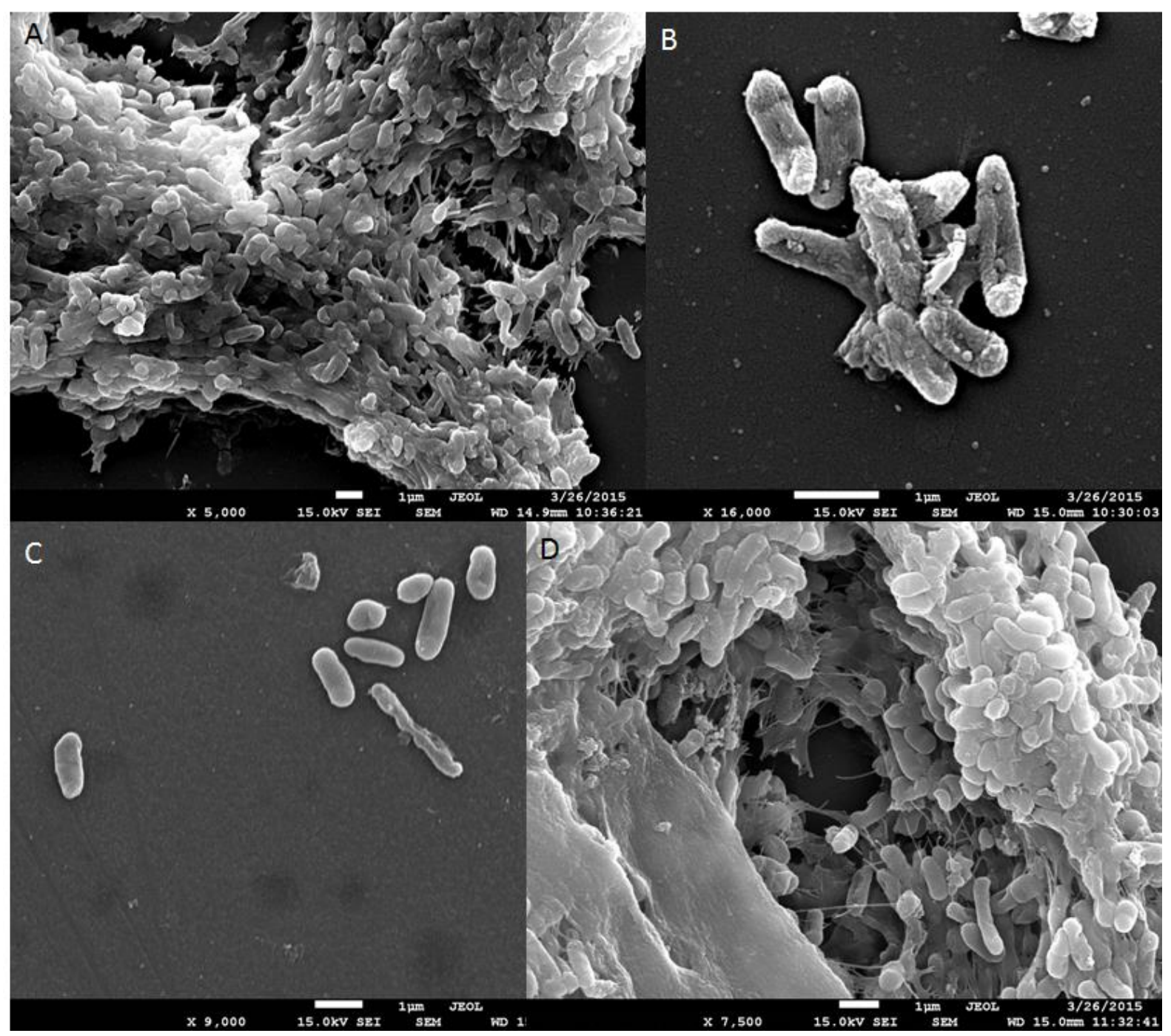

Figura 27. Células do tipo colonial 2B observadas por microscopia eletrônica de varredura. Os aumentos utilizados estão indicados abaixo de cada imagem.

\subsubsection{Extração de DNA total dos diferentes tipos coloniais}

O DNA total das diferentes colônias obtidas inicialmente (no meio contendo apenas ampicilina, estreptomicina e cloranfenicol) foi extraído pelo método de fervura e sua concentração e qualidade foram avaliados em gel de agarose $1 \%$ corado com brometo de etídio (Figura 28). Pode-se observar que a extração teve eficiência variável, já que as bandas apresentaram-se com intensidades diferentes, mas o DNA apresentava boa qualidade, uma vez que havia pequeno grau de fragmentação. Apesar de várias tentativas, não foi possível a extração de DNA das colônias tipo 5, talvez devido às suas dimensões diminutas, o que pode ter resultado em pequenas quantidades de DNA, não detectáveis no gel de agarose. 


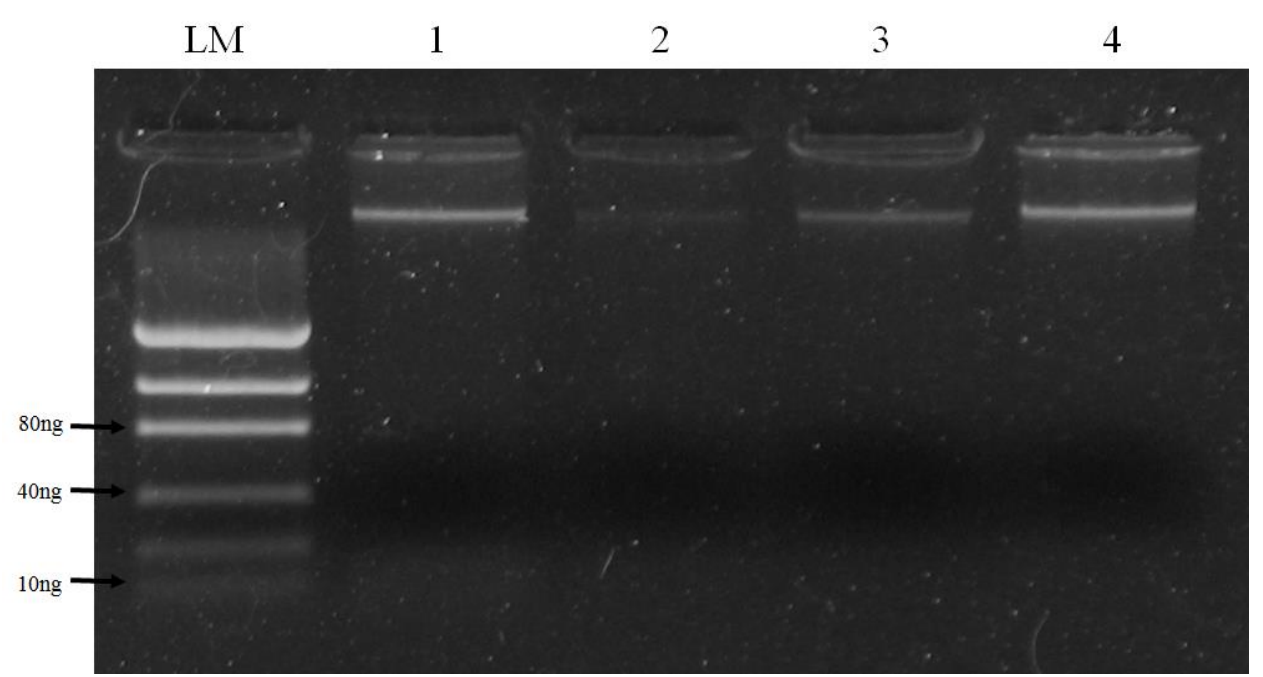

Figura 28. Gel de agarose $1 \%$ corado com brometo de etídio, contendo os DNAs extraídos das colônias cultivadas a partir do solo de cerrado. Os números referem-se aos tipos coloniais, LM: Marcador de massa molecular Low DNA Mass Ladder (Invitrogen).

A partir da comparação entre a intensidade das bandas observadas no gel em relação ao marcador de massa molecular Low DNA Mass Ladder (Invitrogen), estimou-se que a concentração do DNA obtido na extração das colônias cultivadas foi de aproximadamente $9 \mathrm{ng} / \mu \mathrm{L}$ em $1,1 \mathrm{ng} / \mu \mathrm{L}$ em $2,4 \mathrm{ng} / \mu \mathrm{L}$ em 3 e $9 \mathrm{ng} / \mu \mathrm{L}$ em 4 . Experimentos de PCR com iniciadores específicos para Archaea e Bacteria foram então realizados para a verificação da presença de organismos desses domínios no cultivo.

\subsubsection{Experimentos de PCR empregando-se iniciadores específicos para o gene de rRNA 16 S dos domínios Archaea e Bacteria}

A partir das concentrações de DNA estimadas no gel de agarose $1 \%$ de cada um dos tipos coloniais, foram preparadas diluições destes DNAs para que todos atingissem uma concentração final de aproximadamente $1 \mathrm{ng} / \mu \mathrm{L}$. Experimentos de PCR foram então conduzidos com os iniciadores 21f/958r, específicos para a identificação de organismos do domínio Archaea, utilizando-se 1, 2,5 e 5ng de DNA de cada um dos tipos coloniais obtidos.

Ao se analisar os produtos das reações de PCR em gel de agarose $1 \%$ corado com brometo de etídio, foi possível a observação de fragmentos de DNA de tamanho compatível (cerca de $950 \mathrm{pb})$, em pequenas concentrações, apenas a partir das colônias $2(2,5 \mathrm{ng})$ e $3(2,5$ e 5ng) (Figura 29A). Visando otimizar a obtenção de tais fragmentos, reações de 
reamplificação do DNA alvo foram realizadas utilizando-se como molde o DNA amplificado no primeiro ensaio de PCR. Assim, várias alíquotas das amostras 2 e 3 foram utilizadas em replicatas para as reações de reamplificação e, posteriormente, os sistemas referentes à cada amostra foram reunidos e purificados. A reamplificação mostrou-se eficiente e fragmentos em maior concentração puderam ser visualizados no gel de agarose 1\% (Figura 29B). Os DNAs purificados das amostras 2 e 3 foram então enviados diretamente para o sequenciamento automático, sem qualquer etapa de clonagem prévia.

Não foi verificada a presença de fragmentos de DNA amplificados a partir das colônias 1 e 4, sugerindo serem estas compostas somente por membros do domínio Bacteria.

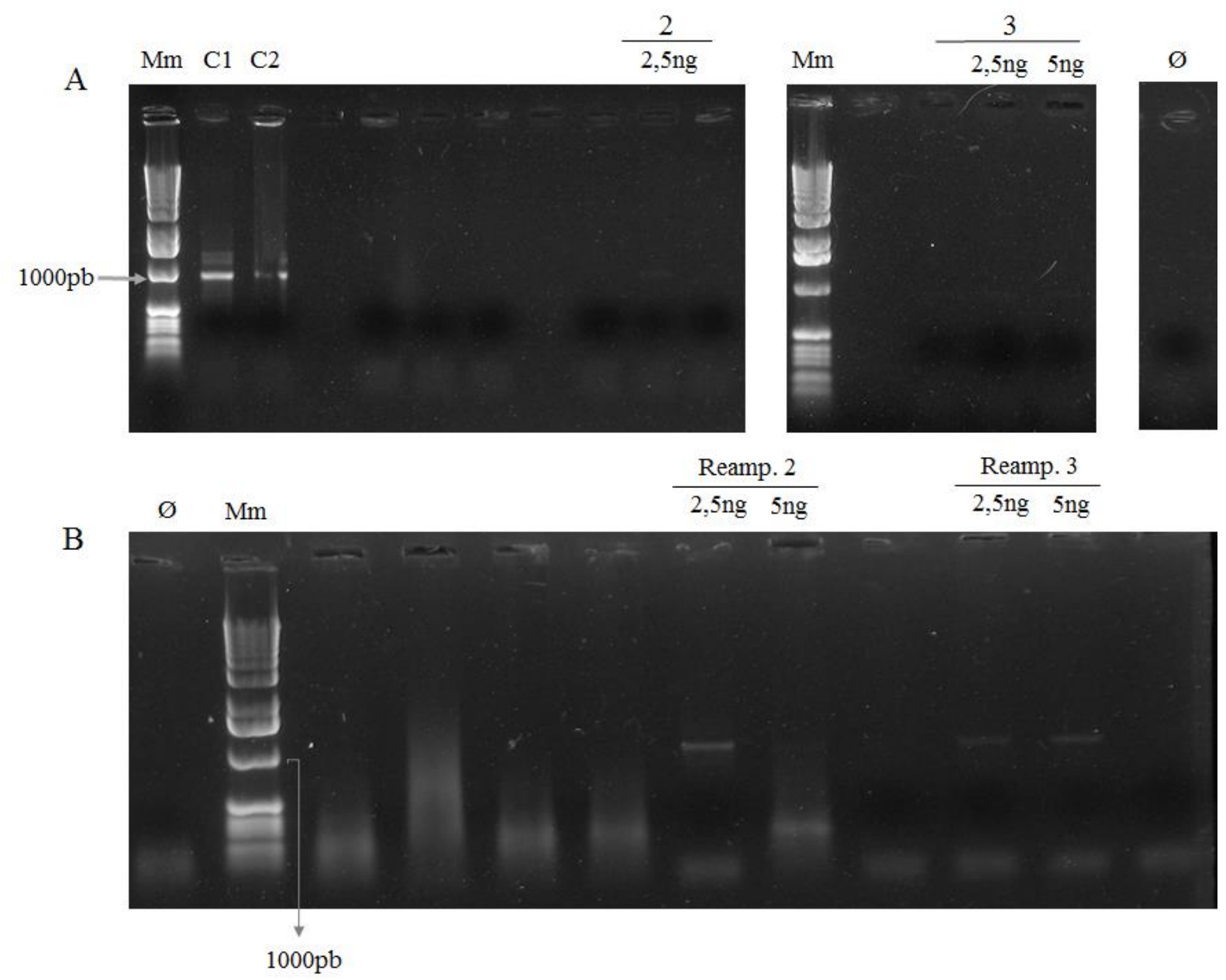

Figura 29. Gel de agarose 1\%, corado com brometo de etídio, revelando os produtos de PCR obtidos de A: colônias 2 e 3, empregando-se os iniciadores 21f/958r. B: Reamplificações das amostras 2 e 3 (Reamp. 2 e Reamp. 3), utilizando-se o DNA obtido no primeiro ensaio de PCR como molde. Mm: marcador de massa molecular 1kb Plus DNA Ladder da Invitrogen; C1 e C2: controles positivos da PCR, onde foram utilizados DNAs genômicos totais de solo de cerrado controle $(\mathrm{Ca})$; $\varnothing$ : controles negativos das PCRs, onde não foi adicionado DNA. 
Visando verificar a presença de bactérias nas culturas, experimentos de PCR com os iniciadores 27f/1492r, específicos para o domínio Bacteria, também foram realizados, empregando-se o DNA total extraído a partir dos quatro tipos coloniais distintos. Foram utilizadas as mesmas concentrações de DNA utilizadas nas PCRs com os iniciadores 21f/958r, ou seja, 1, 2,5 e 5ng para cada amostra. Como pode ser observado na Figura 30, fragmentos de tamanho compatível ao esperado para o gene do rRNA 16S de Bacteria (cerca de 1500 pb) foram amplificados em três das quatro amostras, indicando a presença de bactérias nas colônias 1,2 e 3. Curiosamente, não foi verificada a presença de produtos de amplificação a partir do DNA da colônia 4. Tal resultado suscita questionamentos, uma vez que nos dois ensaios de PCR, específicos para Archaea e Bacteria, não foi observado qualquer indício de amplificação de DNA, sugerindo possíveis problemas técnicos, ou uma possível inespecificidade dos iniciadores empregados.

Por outro lado, a presença de produtos de amplificação utilizando-se iniciadores específicos para ambos os domínios indica a ocorrência de um co-cultivo entre archaeas e bactérias nas amostras 2 e 3. Os DNAs amplificados a partir de diferentes concentrações de uma mesma amostra foram então misturados e purificados conjuntamente. Após a purificação, os DNAs resultantes das amostras 1, 2 e 3 foram enviados diretamente para o sequenciamento automático.

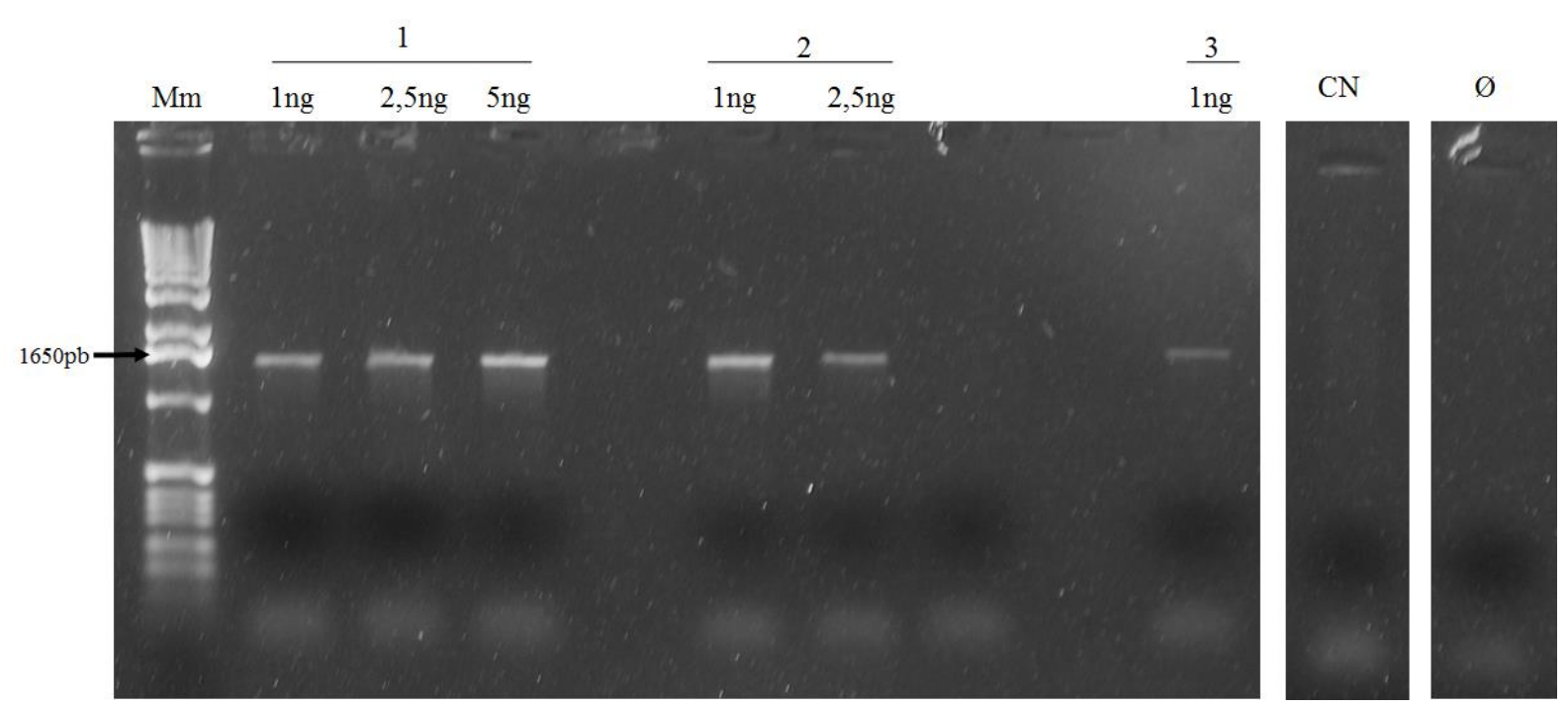

Figura 30. Figura 29. Gel de agarose $1 \%$ corado com brometo de etídio mostrando o DNA amplificado após reação de PCR com iniciadores 27f/1492r, específicos para o gene do rRNA $16 \mathrm{~S}$ de Bacteria. 1, 2 e 3 referem-se aos tipos coloniais; Mm: marcador de massa molecular $1 \mathrm{~kb}$ Plus DNA Ladder da Invitrogen; CN: controle negativo da PCR, onde foi utilizado DNA da archaea Haloferax volcanii; $\varnothing$ : controle negativo da PCR, onde não foi adicionado DNA. 


\subsubsection{Análises de bioinformática das sequências obtidas}

As sequências do gene rRNA $16 \mathrm{~S}$ de bactéria e de archaea obtidas a partir do cultivo foram analisadas quanto a sua qualidade pelo algoritmo PHRED (Ewing et al., 1998). Das duas amostras de rRNA 16S de Archaea enviadas para o sequenciamento (obtidas a partir dos tipos coloniais 2 e 3), apenas a sequência do tipo colonial 2 apresentou valor PHRED acima de 20 para mais de 250 bases, sendo assim a única utilizada para as análises posteriores. Quanto às amostras de rRNA $16 \mathrm{~S}$ de Bacteria obtidas a partir dos tipos coloniais 1, 2 e 3, apenas as sequências de 1 e 2 apresentaram qualidade adequada, ou seja, valor PHRED acima de 20 para mais de 250 nucleotídeos. Assim, apenas essas duas sequências puderam ser classificadas quanto a sua taxonomia.

Desta forma, apesar de terem sido obtidas amplificações com os iniciadores específicos tanto para Archaea quanto para Bacteria a partir do DNA extraído do tipo colonial 3, devido à baixa qualidade das sequências obtidas, não foi possível determinar a classificação dos organismos presentes neste cultivo. Neste caso em particular, pode-se também especular a existência de mais de um tipo de Archaea e/ou Bacteria nesta cultura e, por esta razão, o resultado do sequenciamento foi inconclusivo. Uma abordagem que poderia ser realizada para elucidar tal questão seria a clonagem dos fragmentos amplificados e o sequenciamento posterior de alguns clones.

Na Tabela 14 são apresentadas as sequências de rRNA 16S que foram amplificadas a partir de cada tipo colonial observado no cultivo. São também indicadas aquelas não utilizadas para as análises de bioinformática posteriores, por apresentarem um valor PHRED não adequado (inferior a 20).

Tabela 14. Sequências amplificadas em cada tipo colonial obtido no cultivo.

\begin{tabular}{ccc}
\hline Tipo Colonial & rRNA 16S de Archaea & rRNA 16S de Bacteria \\
\hline 1 & - & $+{ }^{*}$ \\
2 & + & + \\
3 & $+{ }^{*}$ & + \\
4 & - & -
\end{tabular}

* Sequências que não apresentaram qualidade PHRED adequada. Estas sequências não foram utilizadas nas análises de bioinformática posteriores. 


\subsubsection{Classificação taxonômica pelo banco de dados Greengenes}

A sequência do gene rRNA $16 \mathrm{~S}$ obtida a partir dos iniciadores específicos para o domínio Archaea (tipo colonial 2) foi classificada quanto a sua taxonomia utilizando-se o banco de dados Greengenes. A sequência foi classificada com $100 \%$ de identidade até o nível de ordem por este banco, como pode ser visto abaixo, onde k_ representa o domínio, p_o filo, c_a classe e o_a ordem:

$$
\begin{aligned}
& \text { k_Archaea(100); } \\
& \text { p_Crenarchaeota(100); } \\
& \text { c_MBGA(100); } \\
& \text { o_NRP-J(100); }
\end{aligned}
$$

Como já discutido na seção 4.1.7.1, o filo proposto Thaumarchaeota ainda não é considerado pelo Greengenes e os organismos que agora vêm sendo incluídos na ordem NRPJ são aqueles considerados como pertencentes ao grupo I.1c de Thaumarchaeota (Swanson \& Sliwinski, 2013). Assim, de acordo com a classificação do Greengenes, a archaea cultivada neste trabalho pertenceria ao grupo I.1c de Thaumarchaeota, um grupo que ainda não apresenta nenhum representante cultivado e que vem sendo detectado em solos por trabalhos independentes de cultivo (Hansel et al., 2008; Lehtorvita et al., 2009; Bates et al., 2011).

Vale ressaltar que muitas sequências com essa mesma classificação pelo Greengenes foram identificadas nos solos de Cerrado sensu stricto analisados neste trabalho, principalmente na área Controle, mesma área de onde foi retirado o solo para o estabelecimento do cultivo.

Ambas as sequências de Bacteria obtidas a partir do cultivo dos tipos coloniais 1 e 2 foram classificadas com $100 \%$ de identidade com a família Sphingomonadaceae. A bactéria presente no cultivo do tipo colonial 1, do qual não foi possível a amplificação do gene rRNA 16S de Archaea com os iniciadores empregados, foi classificada como pertencente ao gênero Sphingomonas. Já a bactéria presente no cultivo do tipo colonial 2 foi classificada como pertencente ao gênero Novosphingobium, como pode ser visto abaixo, onde k_ representa o domínio, p_o filo, c_a classe, o_a ordem, f_a família e g_o gênero: 


\section{k_Bacteria $(100)$;}

p_Proteobacteria(100);

c_Alphaproteobacteria(100);

o_Sphingomonadales(100);

f_Sphingomonadaceae(100);

g_Novosphingobium(100);

Desta forma, o tipo colonial 2 consiste em um co-cultivo entre uma Archaea pertencente ao grupo I.1c de Thaumarchaeota e uma bactéria pertencente ao gênero Novosphingobium. Apesar de não dispormos de uma cultura pura de Archaea, tal resultado é de grande relevância, uma vez que até o momento não há relatos acerca do cultivo de membros do grupo I.1c em meios de cultura artificiais.

O gênero Novosphingobium foi proposto em 2001 por Takeuchi e colaboradores e passou a incluir espécies anteriormente associadas ao gênero Sphingomonas. Os autores observaram que, baseando-se em sequências quase completas de rRNA $16 \mathrm{~S}$ e outras características de diversas espécies classificadas até então como Sphingomonas, eram formados quatro clados distintos que justificariam a proposta de novos gêneros. Assim, o gênero Novosphingobium incluiria organismos bacilares Gram-negativos, medindo 1 a $3 \mu \mathrm{m} \mathrm{X}$ 0,3 a $0,5 \mu \mathrm{m}$, apresentando motilidade ou não. Organismos pertencentes a este gênero são ubíquos, já tendo sido isolados de diversos tipos de ambiente (Takeuchi et al., 1995; Nohynek et al., 1996; Lim et al., 2007; Saxena et al., 2013), incluindo vários ambientes terrestres como rizosferas (Lin et al., 2014; Kämpfer et al., 2015), águas subterrâneas (Lee et al., 2014), rochas subterrâneas (Balkwill et al., 1997) e diferentes solos (Gupta et al., 2009; Kämpfer et al., 2011).

Existem relatos descrevendo a resistência a agentes antimicrobianos em organismos pertencentes a este grupo (Yabuuchi et al., 2012; Vaz-Moreira et al., 2011), fato que poderia estar relacionado com a persistência destes organismos no cultivo, mesmo após a adição de diversos antibióticos ao meio de cultivo.

É importante ressaltar que a obtenção de culturas puras de archaeas de solo é um processo complexo e desafiador, tendo sido relatados apenas dois casos na literatura até o momento, Nitrososphaera viennensis e Nitrosotalea devanaterra (Tourna et al., 2011; Lehtorvita-Morley et al., 2014). Em ambos os casos, as archaeas apresentaram-se inicialmente em co-cultivo com bactérias, sendo as culturas puras obtidas somente após vários anos de 
repiques sucessivos em meios líquidos submetidos a diluições em série e adição de antibióticos.

Após a identificação do co-cultivo nas amostras do tipo colonial 2, estas colônias foram repicadas em meio de cultivo contendo os antibióticos bacitracina e norfloxacina, visando a inibição do crescimento bacteriano. Como já mencionado no item 4.2.2, as colônias passaram a crescer com diferentes morfologias no meio com estes antibióticos e novas extrações de DNA e reações com os iniciadores específicos para Archaea e Bacteria devem ser realizadas para a constatação da permanência destes organismos no cultivo.

\subsubsection{2. Árvores filogenéticas}

A fim de se obter uma melhor classificação da Archaea cultivada, uma árvore filogenética contendo a sequência de rRNA $16 \mathrm{~S}$ obtida e sequências de outras archaeas isoladas foi construída (Figura 31). Foram escolhidos isolados pertencentes ao grupo I.1a (Cenarchaeum symbiosum, Nitrosopumilus maritimus, Candidatus Giganthauma insulaporcus, Candidatus Giganthauma karukerense, Candidatus Nitrosotalea devanaterra), I.1b (Candidatus Nitrososphaera gargensis, Nitrososphaera viennensis) e o representante do grupo HWCG III (Candidatus Nitrosocaldus yellowstonii) do filo Thaumarchaeota, além de isolados dos filos Euryarchaeota (Haloferax volcanii, Methanosarcina acetivorans e Methanosaeta thermophila) e Crenarchaeota (Pyrobaculum islandicum, Ignicoccus pacificus, Sulfolobus solfactarius, Termoproteus neutrophilus, Thermocladium modestius, Fervidicoccus fontis, Caldisphaera lagunensis e Ignisphaera aggregans). Também foi incluída na árvore, como grupo externo, uma sequência de Acidobacterum sp ainda não cultivada.

A sequência da Archaea cultivada também foi comparada àquelas disponíveis no banco de dados do NCBI por meio da ferramenta BLAST e a sequência que apresentou maior identidade foi selecionada e incluída na árvore. De maneira interessante, a sequência que mais se aproximou à da Archaea cultivada neste trabalho (com identidade de 100\%) consistiu em uma sequência identificada por nosso grupo (Catão et al., 2013), a partir de amostras de solo de cerrado denso (CDa 109 JX 125162.1). Também foram incluídas na árvore outras duas sequências identificadas em solo de mata de galeria no mesmo trabalho (MGa 109 JX125288.1 e MGa89 - 125275.1) e uma sequência obtida a partir de amostras da superfície de rochas de uma caverna da Venezuela (KM214120.1), que também apresentaram elevada identidade com a sequência da Archaea cultivada neste trabalho. As quatro sequências 
mencionadas foram classificadas como pertencentes ao grupo I.1c de Thaumarchaeota pelos autores (Catão et al., 2013; Barton et al., 2014).

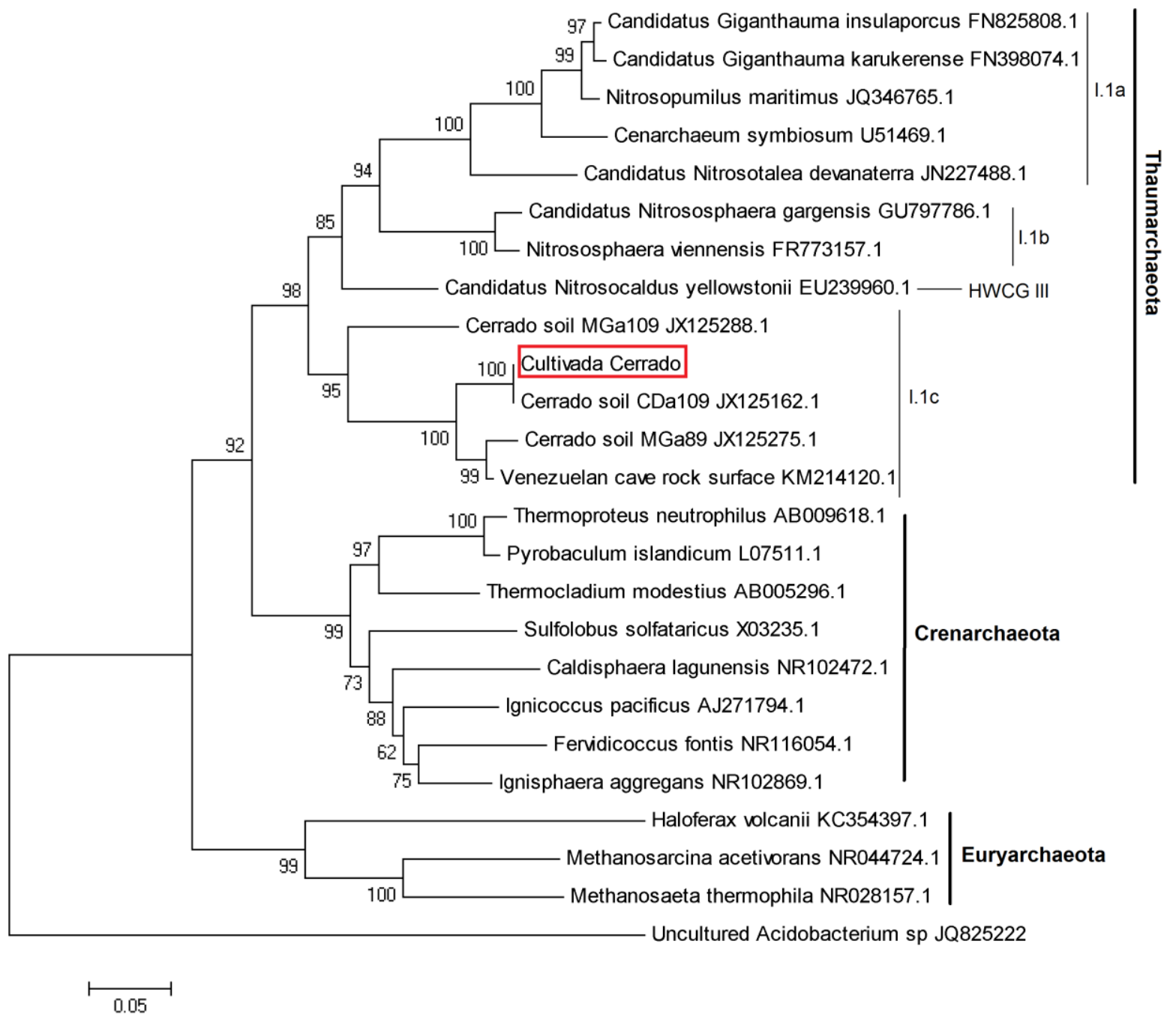

Figura 31. Árvore filogenética com a sequência do gene rRNA 16S da archaea cultivada (denominada Cultivada Cerrado e marcada com o retângulo vermelho) alinhada com sequências de archaeas cultivadas e não cultivadas retiradas de banco de dados do NCBI. Os números de acesso estão mostrados ao lado do nome de cada sequência. A árvore foi construída pelo método Neighbor-joining (Saitou \& Nei, 1987), com o modelo de JukesCantor (Jukes \& Cantor, 1969) e teste de 1000 bootstrap (Felsenstein, 1985). Valores de bootstrap menores que 50 não são mostrados na árvore. A barra de escala indica a distância da similaridade dos ramos. Uma sequência de uma bactéria Acidobacterium sp. foi utilizada como grupo externo. HWCG III: Hot Water Crenarchaeotic Group III.

Como pode ser observado na árvore, a sequência da Archaea cultivada foi posicionada, juntamente com as sequências das outras fitofisionomias do Cerrado e da rocha de caverna retiradas do banco de dados, em um clado à parte no grupo I.1c, pertencente ao 
filo Thaumarchaeota. Além disso, a sequência da Archaea cultivada apresentou forte afiliação (com valor de bootstrap 100) com a sequência previamente identificada em Cerrado Denso (CDa109). Este resultado, aliado ao fato das sequências terem apresentado identidade de $100 \%$ pelo BLAST, indica que há grande probabilidade de se tratarem de sequências de organismos muito próximos, ou até mesmo o mesmo organismo.

Com o objetivo de se relacionar filogeneticamente a sequência da Archaea cultivada e as sequências dos solos de Cerrado sensu stricto obtidas neste trabalho independentemente de cultivo, uma segunda árvore filogenética foi construída a partir de um alinhamento entre estas sequências e outras sequências de archaeas cultivadas e não cultivadas retiradas de banco de dados (Figura 32).

Como pode ser verificado na Figura 32, a sequência da Archaea cultivada (denominada na árvore como Cultivada Cerrado) novamente apresentou-se afiliada ao grupo I.1c de Thaumarchaeota, confirmando seu posicionamento filogenético neste grupo. Além disso, a sequência da Archaea cultivada foi fortemente afiliada (com valor de bootstrap 100) ao clone $\mathrm{Cb88}$, representado por 69 outras sequências, tanto de Controle quanto de Queimada. A forte afiliação entre a sequência da Archaea cultivada, sequências de Cerrado sensu stricto em ambas as condições analisadas, e uma sequência detectada em Cerrado Denso, sugere que estes se tratam de organismos com sequências do gene rRNA 16S muito similares (podendo até ser um mesmo organismo) e que a Archaea cultivada neste trabalho poderia representar um organismo abundante em diferentes fitofisionomias do Cerrado.

Outro ponto importante a ser destacado é o fato de, apesar de mudanças na comunidade microbiana de solos associadas a sazonalidade já terem sido relatadas na literatura (Habekost et al., 2008, Rasche et al., 2011), a cultura de archaea obtida neste trabalho, foi oriunda do solo coletado em janeiro (durante a estação chuvosa). As análises filogenéticas do gene de rRNA $16 \mathrm{~S}$ desta cultura revelaram que tal organismo encontra-se afiliado a sequências identificadas nos solos coletados em setembro, no final na estação seca, durante um período de déficit hídrico (Figura 3). Desta forma, é possível que se trate de um organismo presente nos solos de Cerrado sensu stricto tanto na estação chuvosa quanto na estação seca.

O grupo I.1c de Thaumarchaeota ainda não possui qualquer representante cultivado, fazendo que suas características sejam praticamente desconhecidas. O cultivo de um representante deste grupo pode trazer esclarecimentos acerca do metabolismo, fisiologia, e possíveis papéis ecológicos dos membros deste grupo. 
Embora os resultados obtidos sejam altamente promissores, são necessários ainda alguns ajustes, no sentido de se obter tanto um crescimento mais estável, e se possível, uma cultura pura desta Archaea. Neste sentido, vale ressaltar que nas etapas iniciais de cultivo o $\mathrm{pH}$ do meio de cultura não foi corrigido, estando próximo a 7. No entanto, sabe-se que o $\mathrm{pH}$ dos solos de cerrado é ácido (Haridasan, 1994) e que o pH do solo coletado para a confecção dos meios era 4,7 (Tabela 5). Por outro lado, tendo em vista que a cultura encontrava-se estabelecida nestas condições e a presença da Archaea já havia sido detectada, optamos pela manutenção dos meios nestas condições. Correções futuras do $\mathrm{pH}$ dos meios para valores mais próximos àquele identificado no solo também poderão resultar em um melhor crescimento desta Archaea, especialmente pelo fato das thaumarchaeotas do grupo I.1c serem comumente encontradas em solos ácidos (Jurgens et al., 1997; Kemnitz et al., 2007; Lehtorvita et al., 2009).

Uma determinação mais acurada dos componentes do meio de cultura confeccionado a partir do coado do solo pode levar a um melhor entendimento das necessidades nutricionais deste organismo e permitiria o desenvolvimento de meios mais adequados para seu cultivo. A obtenção do cultivo em meios líquidos também é fundamental para a realização de diversas análises e a suplementação dos meios líquidos com diferentes fontes nutricionais poderão também auxiliar no estabelecimento do cultivo nestas condições.

Além disso, mesmo sem a obtenção de uma cultura pura desta Archaea, caso seja determinada uma predominância das archaeas sobre as bactérias no cultivo, o sequenciamento e reconstrução do genoma completo desta Archaea poderia ser realizado. Desta forma, muitas informações sobre o organismo seriam reveladas e novas estratégias para o cultivo deste e outros membros do grupo I.1c poderiam ser traçadas. 


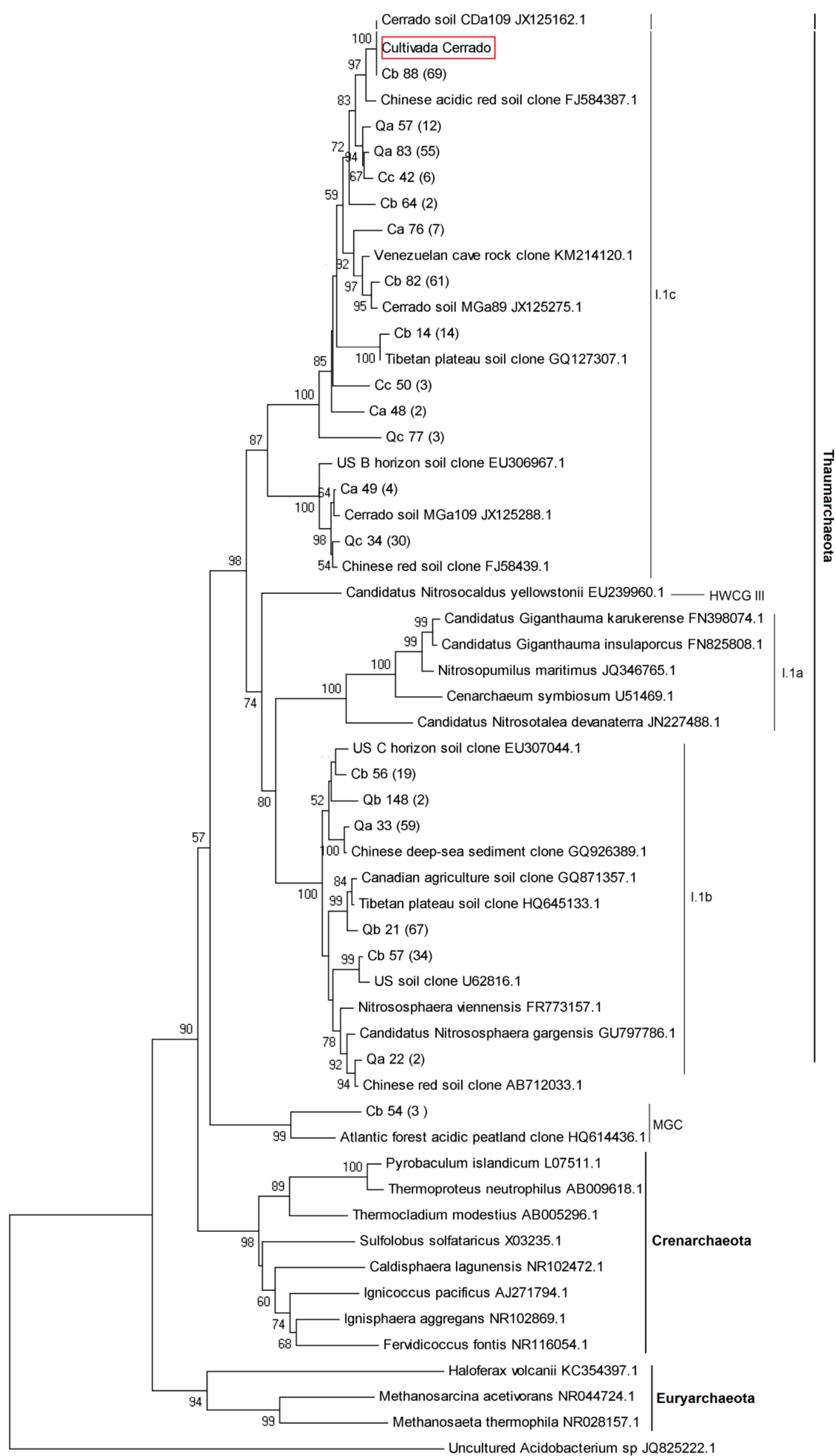


Figura 32. Árvore filogenética com a sequência do gene rRNA $16 \mathrm{~S}$ da archaea cultivada (denominada Cultivada Cerrado e marcada com o retângulo vermelho) alinhada com sequências de archaeas cultivadas e não cultivadas retiradas de banco de dados do NCBI. Os números de acesso estão mostrados ao lado do nome de cada sequência. Também foram incluídas na árvore as sequências dos representantes de cada OTU (3\%) de Controle e Queimada, obtidas pela abordagem independente de cultivo. Os valores indicados entre parênteses ao lado do nome de cada clone indicam o número de sequências representadas pela OTU. A árvore foi construída pelo método Neighbor-joining (Saitou \& Nei, 1987), com o modelo de Jukes-Cantor (Jukes \& Cantor, 1969) e teste de 1000 bootstrap (Felsenstein, 1985). Valores de bootstrap menores que 50 não são mostrados na árvore. A barra de escala indica a distância da similaridade dos ramos. Uma sequência de uma bactéria Acidobacterium sp. foi utilizada como grupo externo. MCG: Miscellaneous Crenarchaeotic Group. HWCG III: Hot Water Crenarchaeotic Group III. 


\section{Conclusões}

- Archaeas do filo Thaumarchaeota, pertencentes ao grupo I.1b e I.1c, são dominantes nos solos de Cerrado sensu stricto típico da Reserva Ecológica do IBGE.

- Os solos de áreas de Cerrado sensu stricto protegidas do fogo ou submetidas a queimadas frequentes apresentam uma comunidade de Archaea com riqueza e diversidade similares.

- As curvas de rarefação obtidas atingiram o platô em todas as amostras até mesmo para o nível de espécie (3\% de dissimilaridade), indicando que a amostragem dos solos de Cerrado sensu stricto em ambas as condições foi suficiente.

- É possível que haja uma diferença de abundância entre membros do grupo I.1b e I.1c entre a área protegida do fogo há muitos anos e a área submetida a queimadas bienais, sendo necessários mais estudos para um melhor esclarecimento dos efeitos das queimadas frequentes na abundância destes organismos nos solos de Cerrado.

- Foram detectadas sequências do gene amoA de Archaea nos solos das duas condições analisadas, constatando-se a ocorrência de archaeas com o potencial para a oxidação de amônia em solos de Cerrado e o seu posicionamento nas árvores filogenéticas construídas sugerem tratarem-se de sequências de AOAs ainda não descritas.

- A metodologia empregada neste estudo possibilitou o estabelecimento de um cocultivo entre uma archaea e uma bactéria de solo de Cerrado sensu stricto.

- A archaea cultivada, de acordo com o posicionamento na árvore filogenética, pertence ao grupo I.1c do filo Thaumarchaeota, um grupo que ainda não apresenta qualquer relato de cultivo na literatura. 


\section{Perspectivas}

- Uso de outros marcadores filogenéticos para uma descrição mais ampla da comunidade de archaeas nos solos de Cerrado.

- A realização de ensaios de PCR quantitativa para auxiliar na detemrinação de diferenças quanto a abundância dos grupos de Thaumarchaeota nos solos de Cerrado sensu stricto protegidos do fogo ou submetidos a queimadas frequentes. Além disso, PCRs quantitativas também poderão ser realizadas empregando-se iniciadores para o gene amoA de Archaea, visando assim a determinação de diferenças de abundância das archaeas com o potencial para oxidação de amônia nos solos de ambas as condições.

- Extrações de DNA das colônias obtidas após a adição de norfloxacina e bacitracina no meio de cultivo e ensaios de PCR com iniciadores específicos para o rRNA $16 \mathrm{~S}$ dos domínios Archaea e Bacteria visando a constatação da permanência dos organismos de ambos os domínios no culivo.

- A utilização de técnicas de hibridização fluorescente in situ (FISH) com sondas específicas para os domínios Archaea e Bacteria visando determinar a proporção entre archaeas e bactérias presentes no cultivo estabelecido neste estudo. Caso seja observada uma predominância de archaeas, extrações de DNA para tentativas de reconstrução de um genoma completo deste organismo poderão ser realizadas, o que traria importantes informações sobre sua biologia.

- Uma melhor determinação dos componentes do meio de cultura e sua suplementação com diferentes compostos poderiam auxiliar no estabelecimento do cultivo em meios líquidos, o que facilitaria a utilização de certas abordagens que visem a obtenção de culturas puras da archaea, como filtragem e suplementação sucessiva do meio com diferentes antibióticos. Além disso, uma vez estabelecido o cultivo em meio líquido, certas análises fisiológicas poderiam ser conduzidas para uma melhor caracterização da archaea cultivada.

- Realização de estudos que descrevam as comunidades de Archaea nos solos antes e logo após as queimadas, visando determinar os efeitos imediatos das queimadas nestas comunidades. 


\section{Referências Bibliográficas}

Alain, K. \& Querellou, J. 2009. Cultivating the uncultured: limits, advances and future challenges. Extremophiles, 13:583-594.

Albers, S. V. \& Meyer, B. H. 2011. The archaeal cell envelope. Nature, 9(6):414-427.

Aller, J. Y. \& Kemp, P. F. 2008. Are Archaea inherently less diverse than Bacteria in the same environments? FEMS Microbiology Ecology, 65(1):74-87.

Altschul, S. F.; Gish, W.; Miller, W; Myers, E.W.; Lipman, D.J. 1990. Basic local alignment search tool. Journal of Molecular Biology, 215:403-410.

Amann, R. I.; Ludwig, W.; Schleifer, K. H. 1995. Phylogenetic identification and in situ detection of individual microbial cells without cultivation. Microbiological Reviews, 59(1):143-169.

Aoi, Y.; Kinoshita, T.; Hata, T.; Ohta, H.; Obokata, H.; Tsuneda, S. 2009. Hollow-fiber membrane chamber as a device for in situ environmental cultivation. Applied and Environmental Microbiology, 75(11):3826-3833

Andrei, A. S.; Banciu, H. L.; Oren, A. 2012. Living with salt: metabolic and phylogenetic diversity of archaea inhabiting saline ecosystems. FEMS Microbiology Letters, 330(1): 1-9.

Araújo, J. F.; Castro, A. P.; Costa, M. M. C.; Togawa, R.C.; Pappas, G. J.; Quirino, B. F.; Bustamante, M. M. C.; Williamson, L.; Handelsman, J.; Krüger, R. H. 2012. Characterization of soil bacterial assemblies in Brazilian savanna-like vegetation reveals acidobacteria dominance. Microbial Ecology, 64(3):760-770.

Auguet, J. C.; Barberan, A.; Casamayor, E. O. 2010. Global ecological patterns in uncultured Archaea. The ISME journal, 4(2):182-190.

Balch, W. E.; Fox, G. E.; Magrum, L. J.; Woese, C. R.; Wolfe, R. S. 1979. Methanogens: reevaluation of a unique biological group. Microbiological Reviews, 43(2):260-296.

Balkwill, D.L.; Drake; G.R.; Reeves, R,H,; Fredrickson, J. K.; White, D. C.; Ringelberg, D.B.; Chandler, D. P.; Romine, M.F.; Kennedy, D.W.; Spadoni, C.M. 1997. Taxonomic study of aromatic-degrading bacteria from deep-terrestrial-subsurface sediments and description of Sphingomonas aromaticivorans sp. nov., Sphingomonas subterranea sp. nov., and Sphingomonas stygia sp. nov. International Journal of Systematic Bacteriology, 47(1):191-201. 
Bano, N.; Ruffin, S.; Ransom, B.; Hollibaugh, J. T. 2004. Phylogenetic composition of artic ocean archaeal assemblages and comparison with antartic assemblages. Applied and Environmental Microbiology. 70(2): 781-789.

Bates, S. T.; Berg-Lyons, D.; Caporaso, J. G.; Walters, W. A.; Knight, R.; Fierer, N. 2011. Examining the global distribution of dominant archaeal populations in soil. The ISME journal, 5(5):908-917.

Barns, S. M.; Fundyga, R.E.; Jeffries, M.W.; Pace, N.R. 1994. Remarkable archaeal diversity detected in a Yellowstone National Park hot spring environment. Proceedings of the National Academy of Science of USA, 91(5):1609-1613.

Barns, S. M.; Delwiche, C. F.; Palmer, J.D.; Pace, N.R. 1996. Perspectives on archaeal diversity, thermophily and monophyly from environmental rRNA sequences. Proceedings of the National Academy of Science of USA, 93(17):9188-9193.

Barton, H. A.; Giarrizzo, J. G.; Suarez, P.; Robertson, C. E.; Broering, M. J.; Banks, E. D.; Vaishampayan, P. A.; Venkateswaran, K. 2014. Microbial diversity in a Venezuelan orthoquartzite cave is dominated by the Chloroflexi (Class Ktedonobacterales) and Thaumarchaeota Group I.1c. Frontiers in microbiology, $5(615): 1-14$.

Bartossek, R.; Spang, A.; Weidler, G.; Lanzen, A.; Schleper, C. 2012. Metagenomic analysis of ammoniaoxidizing archaea affiliated with the soil group. Frontiers in Microbiology, 3(208):1-14.

Beman, J. M. \& Francis, C. A. 2006. Diversity of ammonia-oxidizing archaea and bacteria in the sediments of a hypernutrified subtropical estuary: Bahía del Tóbari, Mexico. Applied and Environmental Microbiology, 72(12):7767-7777.

Beveridge, T. J. \& Schultze-Lam, S. 1996. The response of selected members of the Archaea to the Gram stain. Microbiology, 142:2887-2892.

Bintrim, S. B.; Donohue, T. J.; Handelsman, J.; Roberts, G. P.; Goodman, R. M. 1997. Molecular phylogeny of Archaea from soil. Proceedings of the National Academy of Science of USA, 94:277-282.

Blainey, P. C.; Mosier, A. C.; Potanina, A.; Francis, C. A.; Quake, S. R. 2011. Genome of a low-salinity ammonia-oxidizing archaeon determined by single-cell and metagenomic analysis. PloS one, 6(2): e16626.

Blochl, E.; Rachel, R.; Burggraf, S.; Hafenbradl, D.; Jannasch, H.W.; Stetter, K.O. 1997. Pyrolobus fumarii, gen. and sp. nov., represents a novel group of archaea, extending the upper temperature limit for life to 113 degrees C. Extremophiles, 1(1):14-21. 
Bresolin, J. D.; Bustamante, M. M. C.; Krüger, R. H.; Silva, M. R. S. S.; Perez, K. S. 2010. Structure and composition of bacterial and fungal community in soil under soybean monoculture in the Brazilian Cerrado. Brazilian Journal of Microbiology, 41:391-403.

Brochier, C.; Gribaldo, S.; Zivanovic, Y.; Confalonieri, F.; Forterre, P. 2005. Nanoarchaea: representatives of a novel archaeal phylum or a fast-evolving euryarchaeal lineage related to Thermococcales? Genome Biology., 6(5):R42.

Brochier-Armanet, C.; Boussau, B.; Gribaldo, S.; Forterre, P. 2008. Mesophilic Crenarchaeota: proposal for a third archaeal phylum, the Thaumarchaeota. Nature Reviews Microbiology, 6(3):245-252.

Brochier-Armanet, C.; Forterre, P.; Gribaldo, S. 2011. Phylogeny and evolution of the Archaea: one hundred genomes later. Current Opinion in Microbiology, 14(3): 274-281.

Brochier-Armanet, C.; Gribaldo, S.; Forterre, P. 2012. Spotlight on the Thaumarchaeota. The ISME journal, $6(2): 227-230$.

Buckley, D. H.; Graber, J. R.; Schmidt, T. M. 1998. Phylogenetic analysis of nonthermophilic members of the kingdom crenarchaeota and their diversity and abundance in soils. Applied and Environmental Microbiology, 64(11):4333-4339.

Burns, D.G.; Camakaris, H.M.; Janssen, P.H.; Dyall-Smith, M.L. 2004. Cultivation of Walsby's square haloarchaeon. FEMS Microbiology Letters, 238:469-473.

Canfield, D. E.; Glazer, A. N.; Falkowski, P. G. 2010. The evolution and future of Earth's nitrogen cycle. Science, 330(6001):192-196.

Castro, A. P.; Quirino, B. F.; Pappas, G.; Kurokawa, A. S.; Neto, E; L.; Krüger, R. H. 2008. Diversity of soil fungal communities of Cerrado and its closely surrounding agriculture fields. Archives of Microbiology, 190:129-139.

Catão, E.; Castro, A. P.; Barreto, C. C.; Krüger, R. H.; Kyaw, C. M. 2013. Diversity of Archaea in Brazilian savanna soils. Archives in Microbiology, 195(7):507-512.

Chan, Y. K.; McCormick, W. A.; Ma, B. L. 2013. Effects of inorganic fertilizer and manure on soil archaeal abundance at two experimental farms during three consecutive rotation-cropping seasons. Applied Soil Ecology, 68:26-35.

Chaban, B.; Ng, S.Y.M.; Jarrell, K.F. 2006. Archaeal habitats - from the extreme to the ordinary. Canadian Journal of Microbiology, 52:73-116. 
Chao, A. 1984. Nonparametric estimation of the number of classes in a population. Scandinavian Journal of Statistics, 11:265-270.

Chao, A. \& Lee, S. M. 1992. Estimating the number of classes via sample coverage. Journal of the American Statistical Association, 87(417):210-217.

Connon, S.A. \& Giovannoni, S.J. 2002. High-throughput methods for culturing microorganisms in very-lownutrient media yield diverse new marine isolates. Applied and Environmetal Microbiology, 68:3878-3885.

Coutinho, L. M. 1976. Contribuição ao conhecimento do papel ecológico das queimadas na floração de espécies do cerrado. São Paulo: USP. Tese Livre Docência.

Coutinho, L. M. 1990. Fire in the ecology of the Brazilian Cerrado. In: Fire in the tropical biota: ecosystem processes and global challenges (Goldammer, J. G., ed). Berlin: Springer Verlag. p. 82-105.

Darland, G.; Brock, T. D.; Samsonoff, W.; Conti, S. F. 1970. A thermophilic, acidophilic mycoplasma isolated from a coal refuse pile. Science, 170(3965): 1416-1418.

Delmont, T.O.; Robe, P.; Cecillon, S.; Clark, I.M.; Constancias, F.; Simonet, P.; Hirsch, P.R.; Vogel, T.M. 2011. Accessing the Soil Metagenome for Studies of Microbial Diversity. Applied and Environmental Microbiology, 77(4): 1315-1324.

DeLong, E.F. 1992. Archaea in costal marine environments. Proceedings of the National Academy of Science of USA, 89:5685-5689.

DeLong, E.F.; Wu, K.Y.; Prézelin, B.B.; Jovine, R.V. 1994. High abundance of Archaea in Antartic marine picoplankton. Nature, 371:695-697.

DeLong, E. F. 1998. Everything in moderation: Archaea as 'non-extremophiles'. Current Opinion in Genetics and Development, 8(6):649-654.

DeRosa, M.; Trincone, A; Nicolaus, B.; Gambacorta, A. 1991. In: Life Under Extreme Conditions (diPrisco, G. ed). Berlin: Springer. p. 61-87.

DeSantis, T. Z.; Hugenholtz, P.; Larsen, N.; Rojas, M.; Brodie, E. L.; Keller, K.; Huber, T.; Dalevi, D.; Hu, P.; Andersen, G. L. 2006. Greengenes, a chimera-cheked 16S rRNA gene database and workbench compatible with ARB. Applied and Environmental Microbiology, 72(7):5069-5072. 
Dridi, B.; Fardeau, M.; Ollivier, B.; Raoult, D.; Drancourt, M. 2011. The antimicrobial resistence pattern of cultured human methanogens reflects the unique phylogenetic position of archaea. Journal of Antimicrobial Chemotherapy, 66:2038-2044.

Dridi, B.; Raoult, D.; Drancourt, M. 2011. Archaea as emerging organisms in complex human microbiomes. Anaerobe, 17(2):56-63.

Dridi, B. 2012. Laboratory tools for detection of archaea in humans. Clinical Microbiology and Infection, 18(9): 825-833.

Eckburg, P. B.; Lepp, P.W.; Relman, D. A. 2003. Archaea and Their Potential Role in Human Disease. Infection and Immunity, 71(2):591-596.

Eiten, G. 1994. Vegetação do Cerrado. In: Cerrado: caracterização, ocupação e perspectivas (Novaes-Pinto, M. ed). Brasília: Editora Universidade de Brasília. Capítulo 1, p. 17 a 73.

Elkins, J. G.; Podar, M.; Graham, D. E.; Makarova, K. S.; Wolf, Y.; Randau, L.; Hedlund, B. P.; BrochierArmanet, C.; Kunin, V.; Anderson, I.; Lapidus, A.; Goltsman, E.; Barry, K.; Koonin, E. V.; Hugenholtz, P.; Kyrpides, N.; Wanner, G.; Richardson, P.; Keller, M.; Stetter, K. O. 2008. A korarchaeal genome reveals insights into the evolution of the Archaea. Proceedings of the National Academy of Sciences of USA, 105(23): 8102-8107.

Etto, R. M.; Cruz, L. M.; Jesus, E. C.; Galvão, C. W., Galvão, F.; Souza, E. M.; Pedrosa, F. O. Steffens, M. B. R. 2012. Prokariotic commuinities of acidic peatlands from the Southern Brazilian Atlantic Forest. Brazilian Journal of Microbiology. 661-674.

Ewing, B.; Hillier, L.; Wendl, M. C.; Green, P. 1998. Base-calling of automated sequencer traces using Phred. I. accuracy assessment. Genome Research, 8:175-185.

Felsenstein, J. 1985. Confidence limits on phylogenies: an approach using the bootstrap. Evolution, 39:783-791.

Fiala, G. \& Stetter, K.O. 1986. Pyrococcus furiosus sp. nov. representes a novel genus of marine heterotrophic archaebacteria growing optimally at $100^{\circ} \mathrm{C}$. Archives of Microbiology, 145:56-61.

Forney, L. J.; Zhou, X.; Brown, C. J. 2004. Molecular microbial ecology: land of the one-eyed king. Current Opinion in Microbiology, 7(3):210-220.

Fox, G. E.; Pechman, K. R.; Woese, C. R. 1977. Comparative cataloging of 16S ribosomal ribonucleic acid: molecular approach to procaryotic systematics. International Journal of Systematic Bacteriology, 27(1):44-57. 
Fox, G. E.; Wisotzkey, J. D.; Jurtshuk, P. 1992. How close is close: 16s rRNA sequence identity may not be sufficient to guarantee species identity. International Journal of Systematic Bacteriology, 42(1):166-170.

França, H.; Ramos-Neto, M. B.; Setzer, A. 2007. O fogo no Parque Nacional das Emas (Série Biodiversidade 27). Brasília: MMA. p. 1-140.

Francis, C. A.; Roberts, K. J.; Beman, J. M.; Santoro, A. E.; Oakley, B. B. 2005. Ubiquity and diversity of ammonia-oxidizing archaea in water columns and sediments of the ocean. Proceedings of the National Academy of Science of USA, 102(41):14683-14688.

Fuhrman, J. A.; McCallum, K.; Davis, A. A. 1993. Phylogenetic diversity of subsurface marine microbial communities from the Atlantic and Pacific oceans. Applied and environmental microbiology, 59(5): 1294-1302.

Gavrish, E.; Bollmann, A.; Epstein, S.; Lewis, K. 2008. A trap for in situ cultivation of filamentous actinobacteria. Journal of Microbiological Methods, 72:257-262.

Glissman, K.; Chin, K. J.; Casper, P.; Conrad, R. 2004. Methanogenic pathway and archaeal community structure in the sediment of eutrophic Lake Dagow: effect of temperature. Microbial Ecology, 48(3):389399.

Gray, N.D.; Miskin, I. P.; Oksana, K.; Curtis, T.P.; Head, I. M. 2002. Occurrence and activity of Archaea in aerated activated sludge wastewater treatment plants. Environmental Microbiology, 4(3):158-168.

Grohmann, D. \& Werner, F. 2011. Recent advances in the understanding of archaeal transcription. Current Opinion in Microbiology, 14(3):328-334.

Gubry-Rangin, C.; Hai, B.; Quince, C.; Engel, M.; Thomson, B. C.; James, P. Michael Schloter, M.; Griffiths, R. I.; Prosser, J. I.; Nicol, G. W. 2011. Niche specialization of terrestrial archaeal ammonia oxidizers. Proceedings of the National Academy of Sciences of USA, 108(52):21206-21211.

Gupta, S. K.; Lal, D.; Lal, R. 2009. Novosphingobium panipatense sp. nov. and Novosphingobium mathurense sp. nov., from oil-contaminated soil. International Journal of Systematic and Evolutionary Microbiology, 59:156-161.

Habekost, M.; Eisenhauer, N.; Scheu, S.; Steinbeiss, S.; Weigelt, A.; Gleixner, G. 2008. Seasonal changes in the soil microbial community in a grassland plant diversity gradient four years after establishment. Soil Biology and Biochemistry, 40(10):2588-2595. 
Hallam, S. J.; Konstantinidis, K. T.; Putnam, N.; Schleper, C.; Watanabe, Y.; de la Torre, J.; Richardson, P. M.; Delong, E. F.; Sugahara, J.; Preston, C. 2006. Genomic analysis of the uncultivated marine crenarchaeote Cenarchaeum symbiosum. Proceedings of the National Academy of Sciences of USA, 103(48):1829618301.

Hammer, O.; Harper, D. A. T.; Ryan, . D. 2001. PAST: Paleontological statistics software package for education and data analysis. Paleontologia Electronica, 4(1):1-9.

Handelsman, J. 2004. Metagenomics: application of genomics to uncultured microorganisms. Microbiology and Molecular Biology Reviews, 68:669-685.

Hansel, C. H.; Fendorf, S.; Jardine, P. M.; Francis, C. A. 2008. Changes in bacterial and archaeal community structure and functional diversity along geochemically variable soil profile. Applied and Environmental Microbiology, 74(5):1620-1633.

Haridasan, M. 1994. Solos do Distrito Federal. In: Cerrado: caracterização, ocupação e perspectivas (Novaes-Pinto, M. ed). Brasília: Editora Universidade de Brasília. Capítulo 10, p. 321-344.

Hatzenpichler, R.; Lebedeva, E. V.; Spieck, E.; Stoecker, K.; Richter, A.; Daims, H.; Wagner, M. 2008. A moderately thermophilic ammonia-oxidizing crenarchaeote from a hot spring. Proceedings of the National Academy of Sciences of USA, 105(6):2134-2139.

Heck, K. L.; van Belle, G.; Simberloff, D. 1975. Explicit calculation of the rarefaction diversity measurement and the determination of sufficient sample size. Ecology, 56:1459-1461.

Hong, S.; Bunge, J.; Leslin, C.; Jeon, S.; Epstein, S. S. 2009. Polymerase chain reaction primers miss half of rRNA microbial diversity. The ISME journal, 3(12):1365-1373.

Horz, H.P. \& Conrads, G. 2010. The discussion goes on: what is the role of Euryarchaeota in humans? Archaea, 2010: 967271.

Huber, H.; Hohn, M.J.; Stetter, K.O.; Reinhard, R. 2003. A new phylum of Archaea represented by a nanosized hyperthermophilic symbiont. Nature, 417(6884):63-67.

Hughes, J. B.; Hellmann, J. J.; Ricketts, T. H.; Bohannan, B. J. M. 2001. Counting the Uncountable: Statistical Approaches to Estimating Microbial Diversity. Applied and Environmental Microbiology, 67(10):43994406.

Ishino, Y. \& Ishino, S. 2012. Rapid progress of DNA replication studies in Archaea, the third domain of life. Science China, 55(5):386-403. 
Jia, Z. \& Conrad, R. 2009. Bacteria rather than Archaea dominate microbial ammonia oxidation in an agricultural soil. Environmental Microbiology, 11(7):1658-1671.

Jukes, T. H.; Cantor, C. R. 1969. Evolution of proteins molecules. In: Mammalian protein metabolism (Munro, H.N.; ed). Nova York: Academic Press. p. 21-132.

Jung, M. Y.; Park, S. J.; Min, D.; Kim, J. S.; Rijpstra, W. I. C.; Sinninghe Damsté, J. S.; Kim, G. J.; Madsen, E. L.; Rhee, S. K. 2011. Enrichment and characterization of an autotrophic ammonia-oxidizing archaeon of mesophilic crenarchaeal group I.1a from an agricultural soil. Applied and Environmental Microbiology, 77(24):8635-8647.

Jurgens, G.; Lindstrom, K; Saano, A. 1997. Novel group within the kingdom crenarchaeota from boreal forest soil. Applied and Environmental Microbiology, 63(2):803-805.

Kaeberlein, T.; Lewis, K.; Espstein, S. S. 2002. Isolating "Uncultivable" microorganisms in pure culture in a simulated natural environment. Science. 296:1127-1129.

Kämpfer, P.; Young, C. C.; Busse, H. J.; Lin, S. Y.; Rekha, P. D.; Arun, A. B. 2011. Novosphingobium soli sp. nov., isolated from soil. International Journal of Systematic and Evolutionary Microbiology, 61:259263.

Kämpfer, P.; Martin, K.; McInroy, J.A.; Glaeser, S.P. 2015. Proposal of Novosphingobium rhizosphaerae sp. nov., isolated from the rhizosphere. International Journal of Systematic and Evolutionary Microbiology, 65:195-200.

Kates, M. 1993. Membrane lipids of archaea. In: The Biochemistry of Archaea (Archaebacteria) (Kates, M; Kushner, D. J.; Matheson, A. T., eds). Amsterdam: Elsevier. Capítulo 9, p. 261-295.

Kemnitz, D.; Kolb, S.; Conrad, R. 2007. High abundance of Crenarchaeota in a temperate acidic forest soil. FEMS Microbiology Ecology, 60(3):442-448.

Khelaifia, S. \& Drancourt, M. 2012. Susceptibility of archaea to antimicrobial agentes: applications to clinical microbiology. Clinical Microbiology and Infection, 18(9): 841-848.

Kim, J.; Jung, M.; Park, S.; Rijpstra, I. C.; Damsté, J. S. A.; Madsen, E. L.; Min, D.; Kim, J.; Kim, G.; Rhee, S. 2012. Cutivation of a highly enriched ammonia-oxidizing archaeon of thaumarcheotal group I.1b from an agricultural soil. Environmental Microbiology, 14(6):1528-1543.

Klink, C. A. \& Machado, R. B. 2005. A conservação do Cerrado brasileiro. Megadiversidade, 1(1):147-155. 
Krieg, N. R. 1988. Bacterial classification: an overview. Canadian Journal of Microbiology, 34:536-540.

Könneke, M.; Bernhard, A. E.; de la Torre, J. R.; Walker, C. B.; Waterbury, J. B.; Stahl, D. A. 2005. Isolation of an autotrophic ammonia-oxidizing marine archaeon. Nature, 437(7058):543-546.

Kubo, K.; Lloyd, K. G.; Biddle, J. F.; Amann, R.; Teske, A.; Knittel, K. 2012. Archaea of the Miscellaneous Crenarchaeotal Group are abundant, diverse and widespread in marine sediments. The ISME journal, 6(10):1949-1965.

Kuwabara, T.; Minaba; M. Ogi, N.; Kamekura, M. 2007. Thermococcus celericrescens sp. Nov., a fast-growing and cell-fusing hyperthermophilic archaeon from a deep-sea hydrothermal vent. International Journal of Systematic and Evolutionary Microbiology, 57:437-443.

Lane, D. J. 1991. 16S/23S rRNA sequencing. In: Nucleic acid techniques in bacterial systematics (Stackebrandt, E.; Goodfellow, M., eds). New York: John Wiley and Sons. p. 115-175.

Larkin, M. A.; Blackshields, G.; Brown, N. P.; Chenna, R.; McGettigan, P. A.; McWilliam, H.; Valentin, F.; Wallace, I.M.; Wilm, A.; Lopez, R.; Thompson, J.D.; Gibson, T. J.; Higgins, D. G. 2007. Clustal W and Clustal X version 2.0. Bioinformatics, 23(21): 2947-2948.

Lee, J. C.; Kim, S. G.; Whang, K. S. 2014. Novosphingobium aquiterrae sp. nov., isolated from ground water. International Journal of Systematic and Evolutionary Microbiology, 64:3282-3287.

Lehtovirta, L. E.; Prosser, J. I.; Nicol, G. W. 2009. Soil pH regulates the abundance and diversity of Group I.1c Crenarchaeota. FEMS Microbiology Ecology, 70(3):367-376.

Lehtovirta-Morley, L. E.; Stoecker, K.; Vilcinkas, A.; Prosser, J. I.; Nicol, G.W. 2011. Cultivation of an obligate acidophilic ammonia oxidizer from a nitrifying acid soil. Proceedings of the National Academy of Sciences of USA, 108(38):15892-15897.

Lehtovirta-Morley, L. E.; Ge, C.; Ross, J.; Yao, H.; Nicol, G. W.; Prosser, J. I. 2014. Characterisation of terrestrial acidophilic archaeal ammonia oxidisers and their inhibition and stimulation by organic compounds. FEMS Microbiology Ecology, 89:542-552.

Leigh, J.A.; Albers, S.J.; Atomi, H. Allers, T. 2011. Model for genetics in the domain Archaea: methanogens, halophiles, Termococcales and Sulfolobales. FEMS Microbiology Reviews, 35:577-608.

Leininger, S.; Urich, T.; Schloter, M.; Schwark, L.; Qi, J.; Nicol, G. W.; Prosser, J. I.; Schuster, S. C.; Schleper, C. 2006. Archaea predominate among ammonia-oxidizing prokaryotes in soils. Nature, 442(7104):806-809. 
Lemos, L. N.; Fulthorpe, R. R.; Triplett, E. W.; Roesch, L. F. W. 2011. Rethinking microbial diversity analysis in the high throughput sequencing era. Journal of Microbiological Methods, 86(1):42-51.

Li, X.; Xiao, Y.; Ren, W.; Liu, Z.; Shi, J.; Quan, Z. 2012. Abundance and composition of ammonia-oxidizing bacteria and archaea in different types of soil in the Yangtze river estuary. Journal of Zhejiang University Science B, 13(10):769-782.

Lim, Y. W.; Moon, E. Y.; Chun, J. 2007. Reclassification of Flavobacterium resinovorum Delaporte and Daste 1956 as Novosphingobium resinovorum comb. nov., with Novosphingobium subarcticum (Nohynek et al. 1996) Takeuchi et al. 2001 as a later heterotypic synonym. International Journal of Systematic and Evolutionary Microbiology, 57:1906-1908.

Lin, S.Y.; Hameed, A.; Liu, Y. C.; Hsu, Y. H.; Lai, W. A.; Huang, H. I.; Young, C.C. 2014. Novosphingobium arabidopsis sp. nov., a DDT-resistant bacterium isolated from the rhizosphere of Arabidopsis thaliana. International Journal of Systematic and Evolutionary Microbiology, 64:594-598.

Lozupone, C. A.; Hamady, M.; Kelley, S. T.; Knight, R. 2007. Quantitative and qualitative beta diversity measures lead to different insights into factors that structure microbial communities. Applied and Environmental Microbiology, 73(5):1576-1585.

Lozupone, C. A. \& Knight, R. 2008. Species divergence and the measurement of microbial diversity. FEMS Microbiology Reviews, 32(4):557-578.

Ludwig, W.; Schleifer, K. W. 1994. Bacterial phylogeny based on 16S and 23S rRNA sequence analysis. FEMS Microbiology Reviews, 15:155-173.

Luque, R.; González-Domenech, C.M.; Llamas, I.; Quesada, E.; Béjar, V. 2012. Diversity of culturable halophilic archaea isolated from Rambla Salada, Murcia (Spain). Extremophiles, 16(2):205-213.

Magrum, L. J.; Luehrsen, K. R.; Woese, C. R. 1978. Are extreme halophiles actually "bacteria"? Journal of Molecular Evolution, 11(1):1-8.

Matte-Tailliez, O.; Brochier, C.; Forterre, P.; Philippe, H. 2002. Archaeal phylogeny based on ribosomal proteins. Molecular Biology and Evolution, 19(5):631-639.

Mathrani, I. M.; Boone, D. R.; Mah, R. A.; Fox, G. E.; Lau, P. P. 1988. Methanohalophilus zhilinae sp. nov., and Alkaliphilic, Halophilic, Methylotrophic Methanogen. International Journal of Systematics Bacteriology, 38(2):139-142. 
Melo, A. S. 2008. O que ganhamos 'confundindo' riqueza de espécies e equabilidade em um índice de diversidade? Biota Neotropica, 8(3):21-27.

Meng, J.; Xu, J.; Qin, D.; He, Y.; Xiao, X.; Wang, F. 2014. Genetic and functional properties of uncultivated MCG archaea assessed by metagenome and gene expression analyses. The ISME Journal, 8:650-659.

Miranda, H. S.; Bustamante, M. M. C.; Miranda, A. C. 2002. The fire fator. In: The Cerrados of Brazil ecology and natural history of a neotropical savanna. (Oliveira, P. S. \& Marquis, R. J., eds). New York: Columbia University Press. Capítulo 4, p. 51-68.

Miranda, H. S.; Sato, M. N.; Andrade, S. M. A.; Haridasan, M.; Morais, H. C. 2004. Queimadas de cerrado: caracterização e impactos. In: Cerrado: ecologia e caracterização (Aguiar, L. M. S. \& Camargo, A. J. A., eds). Planaltina: Embrapa Informação Tecnológica. p.69-123.

Miranda, H. S.; Neto, W. N.; Neves, B. M. C. 2010. Caracterização das queimadas de Cerrado. In: Efeitos do regime do fogo sobre a estrutura de comunidades de cerrado: resultados do Projeto Fogo (Miranda, H.S., ed). Brasília: Ibama. Capítulo 2, p. 23-34.

Moreira, A.G. 2000. Effects of fire protection on savanna structure in Central Brazil. Journal of Biogeography, 27: $1021-1029$.

Muller, F.; Brissac, T.; Le Bris, N.; Felbeck, H.; Gros, O. 2010. First description of giant Archaea (Thaumarchaeota) associated with putative bacterial ectosymbionts in a sulfidic marine habitat. Environmental Microbiology, 12(8):23-71-2383.

Myers, N.; Mittermeier, R. A.; Mittermeier, C. G.; Fonseca, G. A. B.; Kent, J. 2000. Biodiversity hotspots for conservation priorities. Nature, 403:853-858.

Nannipieri, P.; Ascher, J.; Ceccherini, M. T.; Landi, L.; Pietramellara, G.; Renella, G. 2003. Microbial diversity and soil functions. European Journal of Soil Science, 54:665-670.

Nardoto, G. B. \& Bustamante, M. M. C. 2003. Effects of fire on soil nitrogen dynamics and microbial biomass in savannas of Central Brazil. Pesquisa Agropecuária Brasileira, 38(8):955-962.

Nicol, G. W.; Campbell, C. D.; Chapman, S. J.; Prosser, J. I. 2007. Afforestation of moorland leads to changes in crenarchaeal community structure. FEMS Microbiology Ecology, 60(1):51-59.

Nicol, G. W.; Leininger, S.; Schleper, C.; Prosser, J. I. 2008. The influence of soil pH on the diversity, abundance and transcriptional activity of ammonia oxidizing archaea and bacteria. Environmental Microbiology, 10(11):2966-2978. 
Nohynek, L. J.; Nurmiaho-Lassila, E. L.; Suhonen, E. L.; Busse, H.-J.; Mohammadi, M.; Hantula, J.; Rainey, F.; Salkinoja-Salonen, M. S. 1996. Description of chlorophenol-degrading Pseudomonas sp. strains KF1T, KF3, and NKF1 as a new species of the genus Sphingomonas, Sphingomonas subarctica sp. nov. International Journal of Systematic Bacteriology, 46:1042-1055.

Nunoura, T.; Takaki, Y.; Kakuta, J.; Nishi, S.; Sugahara, J.; Kazama, H.; Chee, G.J.; Hattori, M.; Kanai, A.; Atomi, H.; Takai, K.; Takami, H. 2011. Insights into the evolution of Archaea and eukaryotic protein modifier systems revealed by the genome of a novel archaeal group. Nucleic Acids Research., 39(8):32043223.

Ochsenreiter, T.; Selezi, D.; Quaiser, A.; Bonch-Osmolovskaya, L.; Schleper, C. 2003. Diversity and abundance of Crenarchaeota in terrestrial habitats studied by 16S RNA surveys and real time PCR. Environmental Microbiology, 5(9):787-797.

Oliveira, R. S.; Batista, J. A. N.; Proença, C. E. B.; Bianchetti, L. 1996. Influência do fogo na floração de espécies de Orchidaceae em cerrado. In: Impactos de queimadas em áreas de cerrado e restinga (Miranda, H. S.; Saito, C. H.; Dias, B. F. S., eds.). Brasília: ECL/Universidade de Brasília. p. 61-67.

Oliveira-Filho, A. T. \& Ratter, J. A. 2002. Vegatation Physiognomies and Woody Flora of the Cerrado Biome. In: The Cerrados of Brazil - ecology and natural history of a neotropical savanna. (Oliveira, P. S. \& Marquis, R. J., eds). New York: Columbia University Press. Capítulo 6, p.91-120.

Olsen, G. J.; Lane, D. J.; Giovannoni, S. J.; Pace, N. R.; Stahl, D. A. 1986. Microbial ecology and evolution: A ribosomal RNA approach. Annual Review of Microbiology, 40:337-365.

Olsen, G. J.; Woese, C. R. 1997. Archaeal Genomics: An Overview Minireview. Cell, 89:991-994.

Pester, M.; Schleper, C.; Wagner, M. 2011. The Thaumarchaeota: an emerging view of their phylogeny and ecophysiology. Current Opinion in Microbiology, 14(3):300-306.

Park, H. D.; Wells, G. F.; Bae, H.; Criddle, C. S.; Francis, C. A. 2006. Occurrence of ammonia-oxidizing archaea in wastewater treatment plant bioreactors. Applied and Environmental Microbiology, 72(8): 5643-5647.

Peet, R. K. 1974. The measurement of species diversity. Annual Review of Ecology and Systematics, 5:285307.

Peng, C.; Jiang, H.; Huang, L.; Hou, W.; Yang, J.; Wang, S.; Huang, Q.; Deng, S.; Dong, H. 2013. Abundance and Diversity of Ammonia-Oxidizing Bacteria and Archaea in Cold Springs on the Qinghai-Tibet Plateau. Geomicrobiology Journal, 30(6):530-539. 
Petitjean, C.; Deschamps, P.; López-Gracía, P.; Moreira, D. 2014. Rooting the Domain Archaea by phylogenomic analysis supports the foundation of the new kingdom Proteoarchaeota. Genome Biology and Evolution, 7(1):191-204.

Pester, M.; Schleper, C.; Wagner, M. 2011. The Thaumarchaeota: an emerging view of their phylogeny and ecophysiology. Current Opinion in Microbiology, 14(3):300-306.

Pester, M.; Rattei, T.; Flechl, S.; Gröngröft, A.; Richter, A.; Overmann, J.; Reinhold-Hurek, B.; Loy, A.; Wagner, M. 2012. amoA-based consensus phylogeny of ammonia-oxidizing archaea and deep sequencing of amoA genes from soils of four different geographic regions. Environmental Microbiology, 14(2):525-539.

Pikuta, E.V.; Marsic, D.; Itoh, T.; Bej, A.K.; Tang, J.; Withman, W.B.; Ng, J.D.; Garriott, O.K.; Hoover, R.B. 2007. Thermococcus thioreducens sp. Nov., a novel hyperthermophilic, obligately súlfur-reducing archaeon from a deep-sea hydrothermal vent. International Journal of Systematic and Evolutionary Microbiology, $57: 1612-1618$.

Pivello, V. R.; Coutinho, L. M. 1992. Transfer of macro-nutrientes to the atmosphre during experimental burning in an open cerrado. Journal of Tropical Ecology, 8:487-497.

Pivello, V. R.; Oliveras, I.; Miranda, H. S.; Haridasan, M.; Sato, M. N.; Meirelles, S. T. 2010. Effect of fires on soil nutrient availability in an open savanna in Central Brazil. Plant and Soil, 337:111-123.

Preston, C. M.; Wu, K. Y.; Molinskit, T. F.; Delong, E. F. 1996. A psychrophilic crenarchaeon inhabits a marine sponge: Cenarchaeum symbiosum gen. nov., sp. nov. Proceedings of the National Academy of Sciences of USA, 93:6241-6246.

Prosser, J. I. 2010. Replicate or lie. Environmental Microbiology, 12(7):1806-1810.

Prosser, J.I. \& Nicol, G. 2008. Relative contributions of archaea and bacteria to aerobic ammonia oxidation in the environment. Environmental Microbiology, 10(11):2931-2941.

Quirino, B. F.; Pappas, G. J.; Tagliaferro, A. C.; Collevatti, R. G.; Neto, E. L.; da Silva, M. R. S. S.; Bustamante, M. M. C.; Krüger, R. H. 2009. Molecular phylogenetic diversity of bacteria associated with soil of the savanna-like Cerrado vegetation. Microbiological Research, 164(1):59-70.

Ramos-Neto, M. B. \& Pivello, V. R. 2000. Lightning fires in a Brazilian savanna national park: rethinking management strategies. Environmental Management, 26:675-684.

Rappé, M.S.; Connon, S. A.; Vergin, K. L.; Giovannoni, S. J. 2002. Cultivation of the ubiquitous SAR11 marine bacterioplankton clade. Nature, 418:630-633. 
Rappé, M. S.; Giovannoni, S. J. 2003. The uncultured microbial majority. Annual Reviews of Microbiology, 57:369-394.

Ribeiro, J. F. \& Walter, B. M. T. 1998. Fitofisionomias do bioma Cerrado. In: Cerrado ambiente e flora (Sano, S. M. \& Almeida, S. P., eds). Planaltina: Embrapa-CPAC. Capítulo 3, p.89-168.

Rinke, C.; Schwientek, P.; Sczyrba, A.; Ivanova, N. N.; Anderson, I. J.; Cheng, J. F.; Darling, A.; Malfatti, S.; Swan, B. K.; Gies, E. A.; Dodsworth, J. A.; Hedlund, B. P.; Tsiamis, G.; Sievert, S. M.; Liu, W. T.; Eisen, J. A.; Hallam, S. J.; Kyrpides, N. C.; Stepanauskas, R. Rubin, E. M.; Hugenholtz, P.; Woyke, T. 2013. Insights into the phylogeny and coding potential of microbial dark matter. Nature, 499(7459):431-437.

Robertson, C. E.; Harris, J. K.; Spear, J. R.; Pace, N. R. 2005. Phylogenetic diversity and ecology of environmental Archaea. Current Opinion in Microbiology, 8(6):638-642.

Robertson, C. E.; Spear, J. R.; Harris, J. K.; Pace, N. R. 2009. Diversity and stratification of archaea in a hypersaline microbial mat. Applied and Environmental Microbiology, 75(7):1801-1810.

Rodrigues, T.; Catão, E.; Bustamante, M. C.; Quirino, B. F.; Krüger, R. K.; Kyaw, C. M. 2014. Seasonal effects in a lake sediment archaeal community of the Brazilian savanna. Archaea, 2014:957145.

Rondon, M.R.; August, P.R.; Bettermann, A.D.; Brady, S.F.; Grossman, T.H.; Liles, M.R.; Loiacono, K.A.; Lynch, B.A.; Macneil, I.A.; Minor, C.; Tiong, C.L.; Gilman, M.; Osburne, M.S.; Clardy, J.; Handelsman; J.; Goodman, R.M. 1999. Cloning the soil metagenome: a strategy for accessing the genetic and functional diversity of uncultured microorganisms. Applied Environmental Microbiology, 66(6): 2541-2547.

Rasche, F.; Knapp, D.; Kaiser, C.; Koranda, M.; Kitzler, B.; Zechmeister-Boltenstern, S.; Richter, A.; Sessitsch, A. 2011. Seasonality and resource availability control bacterial and archaeal communities in soils of a temperate beech forest. The ISME journal, 5(3):389-392.

Rosselló-Mora, R. \& Amann, R. 2001. The species concept for prokaryotes. FEMS Microbiology Reviews, 25:39-67.

Saitou, N. \& Nei, M. 1987. The neighbor-joining method: A new method for reconstructing phylogenetic trees. Molecular Biology and Evolution, 4(4):406-425.

Sato, M. N. \& Miranda, H. S. 1996. Mortalidade de plantas lenhosas do Cerrado sensu stricto submetidas a diferentes regimes de queima. In: Impactos de queimadas em áreas de cerrado e restinga (Miranda, H. S.; Saito, C. H.; Dias, B. F. S., eds). Brasília: ECL/Universidade de Brasília. p. 102-111. 
Sauder, L. A.; Engel, K.; Stearns, J. C.; Masella, A. P.; Pawliszyn, R.; Neufeld, J. D. 2011. Aquarium nitrification revisited: Thaumarchaeota are the dominant ammonia oxidizers in freshwater aquarium biofilters. PloS one, 6(8): e23281.

Saxena, A.; Anand, S.; Dua, A.; Sangwan, N.; Khan, F.; Lal, R. 2013. Novosphingobium lindaniclasticum sp. nov., a hexachlorocyclohexane $(\mathrm{HCH})$-degrading bacterium isolated from an $\mathrm{HCH}$ dumpsite. International Journal of Systematic and Evolutionary Microbiology, 63:2160-2167.

Schloss, P. D. \& Handelsman, J. 2004. Status of the microbial census. Microbiology and Molecular Biology Reviews, 68(4):686-691.

Schloss, P. D.; Larget, B. R.; Handelsman, J. 2004. Integration of microbial ecology and statistics: a test to compare gene libraries. Applied and Environmental Microbiology, 70(9):5485-5492.

Schloss, P. D.; Westcott, S. L.; Ryabin, T.; Hall, J. R.; Hartmann, M.; Hollister, E. B.; Lesniewski, R. A.; Oakley, B. B.; Parks, D. H.; Robinson, C. J.; Sahl, J. W.; Stres, B.; Thallinger, G. G.; Van Horn, D. J.; Weber, C. F. 2009. Introducing mothur: Open-source, platform-independent, community-supported software for describing and comparing microbial communities. Applied and Environmental Microbiology, 75(23):7537-7541.

Schleifer, K. H. 2009. Classification of Bacteria and Archaea: past, present and future. Systematic and applied microbiology, 32(8): 533-542

Schleper, C.; Jurgens, G.; Jonuscheit, M. 2005. Genomic studies of uncultivated archaea. Nature Reviews in Microbiolology, 3:479-488.

Schleper, C. \& Nicol, G. W. 2010. Ammonia-oxidizing archaea - physiology, ecology and evolution. Advances in Microbial Physiology, 57:1-41.

Shannon, C. E. \& Weaver, W. 1949. The mathematical theory of communication. Urbana: University of Illinois Press. 117 pp.

Silva, M. R. S. S. 2012. Diversidade de comunidades bacterianas de solo de Cerrado em resposta a diferentes alterações dos ecossistemas. Tese de doutorado, Departamento de Ecologia do Instituto de Ciências Biológicas, Universidade de Brasília.

Silveira, C. B.; Cardoso, A. M.; Coutinho, F. H.; Lima, J. L.; Pinto, L. H.; Albano, R. M.; Clementino, M. M.; Martins, O. B.; Vieira, R. P. 2013. Tropical aquatic Archaea show environment-specific community composition. PloS one, 8(9): e76321. 
Simister, R.; Taylor, M. W. Tsai, P.; Webster, N. 2012. Sponge-microbe associations survive high nutrients and temperatures. Plos One, 7(12):e52220.

Simon, H.M.; Jahn, C.E.; Bergerud, L.T.; Sligerud, K.; Weimer, P.J.; Willis, D.K. 2005. Cultivation of Mesophilic Soil Crenarchaeotes in Enrichment Cultures from Plant Roots. Applied and Environmental Microbiology, 71(8):4751-4760.

Simpson, E. H. 1949. Measurement of diversity. Nature, 163:688.

Singleton, D. R.; Furlong, M. A.; Rathbun, S. L.; Whitman, W. B. 2001. Quantitative comparisons of 16S rRNA gene sequence libraries from environmental samples. Applied and Environmental Biology, 67(9):43744376.

Sleytr, U. B. \& Sara, M. 1997. Bacterial and archaeal S-layer proteins: structure-function relationships and their biotechnological applications. Trends in Biotechnology, 15(1):20-26.

Sliwinski, M. K. \& Goodman, R. M. 2004. Spatial Heterogeneity of Crenarchaeal Assemblages within Mesophilic Soil Ecosystems as Revealed by PCR - Single-Stranded Conformation Polymorphism Profiling. Applied and Environmental Microbiology, 70(3): 1811-1820.

Sogin, M.L.; Morrison, H.G.; Huber, J.A.; Welch, D.M.; Huse, S.M.; Neal, P.R.; Arrieta, J.M.; Hernd, G.J. 2006. Microbial diversity in the deep sea and the underexplored 'rare biosphere'. Proceedings of the National Academy of Sciences of USA, 103(32): 12115-12120.

Spang, A.; Hatzenpichler, R.; Brochier-Armanet, C.; Rattei, T.; Tischler, P.; Spieck, E.; Streit, W.; Stahl, D. A.; Wagner, M.; Schleper, C. 2010. Distinct gene set in two different lineages of ammonia-oxidizing archaea supports the phylum Thaumarchaeota. Trends in Microbiology, 18(8):331-340.

Spang, A.; Poehlein, A.; Offre, P.; Zumbrägel, S.; Haider, S.; Rychlik, N.; Nowka, B.; Schmeisser, C.; Lebedeva, E. V.; Rattei, T.; Böhm, C.; Schmid, M.; Galushko, A.; Hatzenpichler, R.; Weinmaier, T.; Daniel, R.; Schleper, C.; Spieck, E.; Streit, W.; Wagner, M. 2012. The genome of the ammonia-oxidizing Candidatus Nitrososphaera gargensis: insights into metabolic versatility and environmental adaptations. Environmental Microbiology, 14(12):3122-3145.

Staley, J.T. \& Konopka, A. 1985. Measurement of in situ activities of nonphotosynthetic microorganisms in aquatic and terrestrial habitats. Annual Reviews of Microbiology, 39:321-346.

Stieglmeier, M.; Klingl, A.; Alves, R. J. E.; Rittmann, S. K. R.; Melcher, M.; Leisch, N.; Schleper, C. 2014. Nitrososphaera viennensis gen. nov., sp. nov., an aerobic and mesophilic, ammonia-oxidizing archaeon from 
soil and a member of the archaeal phylum Thaumarchaeota. International Journal of Systematic and Evolutionary Microbiology, 64:2738-2752.

Stackebrandt, E. \& Goebel, B. M. 1994. Taxonomic Note: A Place for DNA-DNA Reassociation and 16s rRNA Sequence Analysis in the Present Species Definition in Bacteriology. International Journal of Systematic Bacteriology, 44(4):846-849.

Stackebrandt, E.; Frederiksen, W.; Garrity, G. M.; Grimont, A. D.; Ka, P.; Maiden, M. C. J.; Nesme, X.; Swings, J.; Tru, H. G.; Ward, A. C.; Whitman, W. B. 2002. Report of the ad hoc committee for the re-evaluation of the species definition in bacteriology. International Journal of Systematic and Evolutionary Microbiology, 52:1043-1047.

Streit, W.F. \& Schmitz, R.A. 2004. Metagenomics - the key to the uncultured microbes. Current Opinion in Microbiology, 7(5): 492-498.

Sturm, S.; Schönefeld, V.; Zillig, W.; Janekovic, D. Stetter, K.O. 1980. Structure and function of the DNA dependent RNA polymerase of the archaebacterium Thermoplasma acidophilum. Zentralblatt für Bakteriologie 1 Abt Originale B Hygiene, C1:12-25.

Swanson, C. A.; Sliwinski, M. K. 2013. One-dimensional TRFLP-SSCP is an effective DNA fingerprinting strategy for soil Archaea that is able to simultaneously differentiate broad taxonomic clades based on terminal fragment length polymorphisms and closely related sequences based on single stranded conformation polymorphisms. Journal of Microbiological Methods, 94(3):317-324.

Tamura, K.; Peterson, D.; Peterson, N.; Stecher, G.; Nei, M.; Kumar, S. 2011. MEGA5: Molecular evolutionary genetics analyses using maximum likelihood, evolutionary distance and maximum parsimony methods. Molecular Biology and Evolution, 28: 2731-2739.

Taylor, A. E.; Zeglin, L. H.; Wanzek, T. A.; Myrold, D. D.; Bottomley, P. J. 2012. Dynamics of ammoniaoxidizing archaea and bacteria populations and contributions to soil nitrification potentials. The ISME Journal, 6:2024-2032.

Takeuchi, M.; Sakane, T.; Yanagi, M.; Yamasato, K.; Hamana, K.; Yokota, A. 1995. Taxonomic Study of Bacteria Isolated from Plants: Proposal of Sphingomonas rosa sp. nov., Sphingomonas pruni sp. nov., Sphingomonas asaccharolytica sp. nov., and Sphingomonas mali sp. nov. International Journal of Systematic Bacteriology, 45(2):334-341.

Tekeuchi, M.; Hamana, K. \& Hiraishi, A. 2001. Proposal of the genus Sphingomonas sensu stricto and three new genera, Sphingobium, Novosphingobium and Sphingopyxis, on the basis of phylogenetic and 
chemotaxonomic analyses. International Journal of Systematic and Evolutionary Microbiology, 51:14051417.

Timonen, S. \& Bomberg, M. 2009. Archaea in dry soil environments. Phytochemistry Reviews, 8(3):505-518.

Torsvik, V. \& Øvreas, L. 2002. Microbial diversity and function in soil: from genes to ecosystems. Current Opinion in Microbiology, 5(3):240-245.

Torsvik, V.; Øvreas, L.; Thingstad, T.F. 2002. Prokaryotic diversity - magnitude, dynamics and controlling factors. Science, 296:1064-1066.

Torsvik, V.; Øvreas, L. 2006. Microbial diversity and phylogeny in soil. In: Modern Soil Microbiology. (Elsas, J.D.; Jansson, J.K.; Trevors, J. T., eds) USA: CRC Press, 2a edição. Capítulo 2, p. 23-52.

Tourna, M.; Stieglmeier, M.; Spang, A.; Könneke, M.; Schintlmeister, A.; Urich, T.; Engel, M.; Scloter, M.; Wagner, M.; Richter, A.; Schleper, C. 2011. Nitrososphaera viennensis, an ammonia oxidizing archaeon from soil. Proceedings of the National Academy of Sciences of USA, 108(20):8420-8425.

Tringe, S.G.; von Mering, C.; Kobayashi, A.; Salamov, A.A.; Chen, K.; Chang, H.W.; Podar, M.; Short, J.M.; Mathur, E.J.; Detter, J.C.; Bork, P.; Hugenholtz, P.; Rubin, E.M. 2005. Comparative Metagenomics of Microbial Communities. Science, 308(5721):554-557.

Tsao, J.H.; Kaneshiro, S.M.; Yu, S.S.; Clark, D.S. 1994. Continuous culture of Methanococcus jannaschii, an extremely thermophilic methanogen. Biotechnology and Bioengineering, 43: 258-261.

Vartoukian, S.R.; Palmer, R.M.; Wade, W.G. 2010. Strategies for culture of 'unculturable' bacteria. FEMS Microbiology Letters, 309:1-7.

Vaz-Moreira, I.; Nunes, O. C.; Manaia, C. M. 2011. Diversity and antibiotic resistance patterns of Sphingomonadaceae isolates from drinking water. Applied and Environmental Microbiology, 77(16):5697-5706.

Viana, L. T.; Bustamante, M. M. C.; Molina, M.; Pinto, A. S.; Kisselle, K.; Zepp, R.; Burke, R. A. 2010. Microbial communities in Cerrado soils under native vegetation subjected to prescribed fire under pasture. Pesquisa Agropecuária Brasileira, 46(12):1665-1672.

Vissers, E. W.; Bodelier, P. L. E.; Muyzer, G.; Laanbroek, H. J. 2009. A nested PCR approach for improved recovery of archaeal 16S rRNA gene fragments from freshwater samples. FEMS Microbiology Letters, 298(2):193-198. 
Walker, C. B.; De La Torre, J.R.; Klotz, M.G.; Urakawa, H.; Pinel, N.; Arp, D.J.; Brochier-Armanet, C.; Chain, P.S.G.; Chan, P.P.; Gollabgir, A.; Hemp, J.; Hügler, M.; Karr, E.A.; Könneke, M.; Shin, M.; Lawton, T.J.; Lowe, T.J.; Martens-Habbena, W.; Sayavedra-Soto, L.A.; Lang, D.; Sievert, S.M.; Rosenzweig, A.C.; Manning, G.; Stahl, D.A. 2010. Nitrosopumilus maritimus genome reveals unique mechanisms for nitrification and autotrophy in globally distributed marine crenarchaea. Proceedings of the National Academy of Sciences of USA, 107(19):8818-8823.

Watve, M.; Shejval, V.; Sonawane, C.; Rahalkar, M.; Matapurkar, A.; Shouche, Y.; Patole, M.; Phadnis, N.; Champhenkar, A.; Damle, K.; Karandikar, S.; Kshirsagar, V.; Jog, M. 2000. The 'K' selected oligophilic bacteria; a key to uncultured diversity? Current Science, 78:1535:1542.

Weidler, G. W.; Dornmayr-Pfaffenhuemer, M.; Gerbl, F. W.; Heinen, W.; Stan-Lotter, H. 2007. Communities of archaea and bacteria in a subsurface radioactive thermal spring in the Austrian Central Alps, and evidence of ammonia-oxidizing Crenarchaeota. Applied and Environmental Microbiology, 73(1):259-270.

Wintzingerode, F.; Göbel, U. B.; Stackebrandt, E. 1997. Determination of microbial diversity in environmental samples: pitfalls of PCR-based rRNA analysis. FEMS Microbiology Reviews, 21:213-229.

Woese, C. R.; Fox, G. E. 1977. Phylogenetic structure of the prokaryotic domain: the primary kingdoms. Proceedings of the National Academy of Sciences of USA, 74(11):5088-5090.

Woese, C. R.; Magrum, L. J.; Fox, G. E. 1978. Archaebacteria. Journal of Molecular Evolution, 11(3): 245251.

Woese, C. R.; Kandlert, O.; Wheelis, M. L. 1990. Towards a natural system of organisms: Proposal for the domains. Proceedings of the National Academy of Science of USA, 87:4576-4579.

Wu, Y. \& Conrad, R. 2014. Thaumarchaeota in acidic red soil microcosms. FEMS Microbiology Ecology, $89: 127-134$.

Wuchter, C.; Abbas, B.; Coolen, M. J. L.; Herfort, L.; van Bleijswijk, J.; Timmers, P.; Strous, M.; Teira, E.; Herndl, G. J.; Middelburg, J. J.; Schouten, S.; Damsté, J. S. S. 2006. Archaeal nitrification in the ocean. Proceedings of the National Academy of Science of USA, 103(33):12317-12322.

Xu, M.; Schnorr, J.; Keibler, B.; Simon, H. M. 2012. Comparative analysis of 16S rRNA and amoA genes from archaea selected with organic and inorganic amendments in enrichment culture. Applied and Environmental Microbiology, 78(7):2137-2146.

Yabuuchi, E.; Kosako, Y.; Fujiwara, N.; Naka, T.; Matsunaga, I.; Ogura, H.; Kobayashi, K. 2002. Emendation of the genus Sphingomonas Yabuuchi et al. 1990 and junior objective synonymy of the species of three 
genera, Sphingobium, Novosphingobium and Sphingopyxis, in conjunction with Blastomonas ursincola. International Journal of Systematic and Evolutionary Microbiology, 52:1485-1496.

Yassin, A. F.; Kroppenstedt, R. M.; Ludwig, W. 2003. Corynebacterium glacum sp. nov. International Journal of Systematic and Evolutionary Microbiology, 53:705-709.

Ying, J. Y.; Zhang, L. M.; He, J. Z. 2010. Putative ammonia-oxidizing bacteria and archaea in an acidic red soil with different land utilization patterns. Environmental Microbiology Reports, 2(2):304-312.

You, J.; Das, A.; Dolan, E. M.; Hu, Z. 2009. Ammonia-oxidizing archaea involved in nitrogen removal. Water research, 43(7):1801-1807.

Zaneveld, J. R.; Lozupone, C.; Gordon, J. I.; Knight, R. 2010. Ribosomal RNA diversity predicts genome diversity in gut bacteria and their relatives. Nucleic Acids Research, 38(12):3869-3879.

Zengler, K.; Toledo, G.; Rappé, M.; Elkins, J.; Mathur, E. J.; Short, J. M.; Keller, M. 2002. Cultivating the uncultured. Proceedings of the National Academy of Science of USA. 99(24):15681-15686.

Zhalnina, K.; de Quadros, P. D.; Camargo, F. A. O.; Triplett, E. W. 2012. Drivers of archaeal ammoniaoxidizing communities in soil. Frontiers in microbiology, 3(210):1-9.

Zhalnina, K. V.; Dias, R.; Leonard, M. T.; Quadros, P. D.; Camargo, F. A. O.; Drew, J. C.; Farmerie, W. G.; Daroub, S. H.; Triplett, E. W. 2014. Genome sequence of Candidatus Nitrososphaera evergladensis from Group I.1b Enriched from Everglades Soil Reveals Novel Genomic Features of the Ammonia- Oxidizing Archaea. PloS one, 9(7)21-23.

Zhang, C. L.; Ye, Q.; Huang, Z.; Li, W.; Chen, J.; Song, Z.; Zhao, W.; Bagwell, C.; Inskeep, W. P.; Ross, C.; Gao, L.; Wiegel, J.; Romanek, C. S.; Shock, E. L.; Hedlund, B. P. 2008. Global occurrence of archaeal amoA genes in terrestrial hot springs. Applied and Environmental Microbiology, 74(20):6417-6426.

Zhang, L. M.; Offre, P. R.; He, J. Z.; Verhamme, D. T.; Nicol, G. W.; Prosser, J. I. 2010. Autotrophic ammonia oxidation by soil thaumarchaea. Proceedings of the National Academy of Sciences of USA, 107(40):17240-17245.

Zuckerkandl, E.; Pauling, L. 1965. Molecules as documents of evolutionary history. Journal of theoretical biology, 8(2):357-366. 